\title{
CITY OF LOS ANGELES ARTS DISTRICT FORM-BASED CODE
}

\author{
A Project \\ presented to \\ the Faculty of California Polytechnic State University, \\ San Luis Obispo
}

\author{
In Partial Fulfillment \\ of the Requirements for the Degree \\ Master of City and Regional Planning
}

by

Ryan Jupiter Banuelos

June 2014 
(C) 2014

Ryan Jupiter Banuelos

\section{ALL RIGHTS RESERVED}




\section{COMMITTEE MEMBERSHIP}

TITLE: $\quad$ City of Los Angeles Arts District Form-Based Code

AUTHOR: $\quad$ Ryan Jupiter Banuelos

DATE SUBMITTED: June 2014

COMMITTEE CHAIR: Umut Toker, PhD

Associate Professor of City and Regional Planning

COMMITTEE MEMBER: William Siembieda, PhD

Professor of City and Regional Planning

COMMITTEE MEMBER: Bryan Eck

Planning Associate, City of Los Angeles 


\section{ABSTRACT \\ City of Los Angeles Arts District Form-Based Code}

Ryan Jupiter Banuelos

Los Angeles is experiencing a loss of inventory with Industrial land due to adaptive reuse and property conversion. The primary factors behind the conversions are inconsistent land use regulations and a strong market demand for residential property. In an effort to streamline land use regulation, the city will create a new zoning code. In conjunction with the zoning update, the purpose of this project will be to develop a form-based code for the Los Angeles Arts District. The new land use regulation will explore methods to preserve job producing industrial space and accommodate the growing residential market in the area. Data for this study was collected and presented as a site analysis. The study also includes a literature review that examines the history of land use regulation in Europe and the United States. The site analysis for the Arts District includes an investigation of circulation patterns, economic factors, development profile, community input, and review of planning documents. Research includes a chronological investigation of the Arts District's history, land use policies, and regulations. The study indicates that the Arts District, though primarily industrial, contains multiple residential nodes. Additionally, it reveals that industrial jobs and building stock are at risk from new development. The purpose of The Arts District Form-Based Code, as the new land use regulation, is to create a predicable development pattern that improves the quality of the built environment. 


\section{TABLE OF CONTENTS}

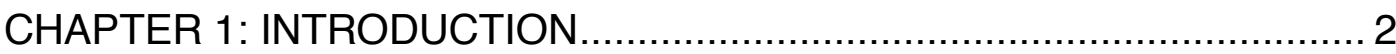

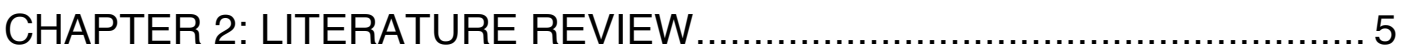

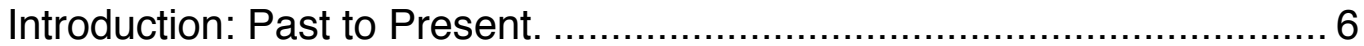

The Beginning of the City in America ........................................... 8

Western Europe, the Dominant Paradigm ...................................... 10

The City in Post-Industrial Europe .............................................. 12

Early Land Use Regulation in the United States.............................. 17

Zoning as an Exclusionary Tool .......................................... 21

Form-Based Codes: Place Based Land Regulation ........................... 23

Los Angeles - Land-Use Evolution and History ............................... 24

CHAPTER 3: RESEARCH QUESTIONS AND METHODOLOGY. ........... 27

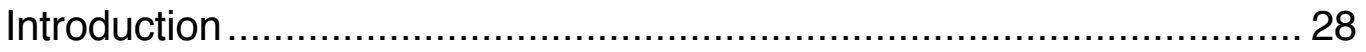

Research Question(s) .................................................... 28

Method 1 - Site Visits ................................................................. 28

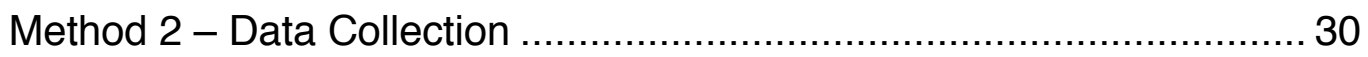

Method 3 - Review of Relevant Documents.................................... 30

Method 4 - Planner Interviews ............................................ 31

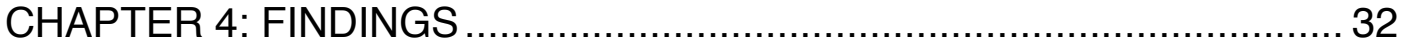

Arts District: History, Industry, and Land Use ................................. 33

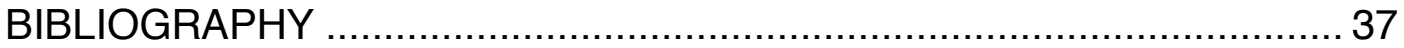

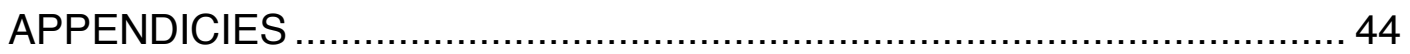

Appendix A: Primary Researcher Notes ......................................... 45

Appendix B: Interview Notes ................................................ 48

Appendix C: Arts District Form-Based Code ................................. 52 
As global society swings into action to reduce carbon emissions, the data ever more clearly points to the need to reduce dependence on vehicular mobility, and to remake the built environment as transit- and pedestrianfriendly places of dense economic and social interaction.

Elizabeth Plater-Zyberk (qtd. in Crawford, 2008, p. xii) 


\section{CHAPTER 1: INTRODUCTION}


The life world - of city dwellers, an urban pattern of activity that repeats over time, but like a fractal, is never exactly the same twice.

David Grahame Shane (qtd. in Shane, 2005)

There are a number of social and physical problems that occur from the foundation of cities. This is because cities have an unpredictable aspect to their nature - they are a juxtaposition of the heterogeneity of urban forms. And within those forms, cities combine "wealth and poverty, efficiency and waste, industry and commerce, residential life and work, pleasure and pain (Shane, 2005, p. 8)." Throughout history cities have attempted to quell the randomness and organize the built environment to create the efficient city. A city where businesses are compatible with their neighbors, the character of a community is preserved, nature is relished, and daily activities do not impede the quality of life of its citizens. Over time, various planning tools were developed to implement these ideals. This report will cover one of those tools known as zoning. In present America, zoning is defined as the regulation of land uses. However, zoning has a long history and at times, has deviated from its original intent. Zoning has been used for a variety of reasons. It has eliminated industrial building's placement next to high-end retail centers, racially segregated groups of people, and protected the single family home. For the most part, zoning's regulatory framework has not changed dramatically since its adoption in the early twentieth century. It has also been 
argued that zoning is one of the driving factors for urban sprawl. Recently, alternative zoning models such as form-based codes have grown in popularity. As cities begin to revitalize their urban cores, new methods of zoning are continually looked at as more viable alternatives to traditional zoning. But with urban revitalization, there is a growing trend and market demand to convert historically significant buildings and districts into highly marketable urban residences. This places industrial lands, which were traditionally built at or near the core of cities, and often on large parcels, at greater risk. In order to study how zoning affects the built environment, the Arts District, an industrial live/work neighborhood in Downtown Los Angeles, will be examined. The development of a form-based code will better represent the Art District's unique building typology and neighborhood character. The form-based code will utilize a set of regulatory standards based upon best practices to alleviate the tension between industrial and residential land uses. A literature review will detail the history of zoning, the advent of form-based codes as an alternative, and the history of land use in Los Angeles. 
CHAPTER 2: LITERATURE REVIEW 


\section{Introduction: Past to Present.}

People say they do not want to live near where they work, but that they would like to work near where they live.

Zev Cohen (Duany, 2000)

The regulation of the built environment has spanned across civilizations and dates back to some of the earliest urban developments recorded in human history. At present, the common term for the regulation of land uses is known as zoning. Since the medieval period, a number of advancements in technology and rapid economic and population growth contributed to the need for some form of regulation to help structure the expansion and transformation of cities. These advancements, which occurred in the years before and after the industrial revolution in Europe, played a catalytic role in the evolution of modern zoning in America.

As far back as $64 \mathrm{CE}$, the Roman Empire built expansive cities. Rome's capital city grew due to population growth through the acquisition of new territories. As a result, the growth also increased the risk of fire damage and deteriorating building conditions. In response, the Roman Emperor Nero introduced building regulations that required the use of stone walls and the development of interior courtyards and porticoes to curtail tenant congestion (Kontokosta, 2013). This excerpt may be one of the first recorded instances in 
which the built environment was regulated to alleviate a city's problems. As cities developed over the next thousand years, they were confronted with physical, social, and economic challenges.

In the early twentieth century, America had the problem of large scale growth, a byproduct of the industrial revolution. The country needed a solution to lessen the toll of unregulated real estate expansion. In the early 1900 s, American planners therefore looked towards Europe and in particular, Germany and England. The two country's land-use ordinances were the defining models in the emergence of zoning in America. To understand landuse zoning in the United States, this chapter will examine literature that concerns technological, economic, political, and social development from the medieval period to the twentieth century. While new tools in zoning have been invented "over the last fifty years - planned unit development, performance, incentive, inclusionary, form-based zoning, etc.," form based zoning will be the primary focus of this study (Hirt, 2013, p. 293). The historical perspective on the evolution of land uses in America will explore the reasoning as to why zoning has remained relatively stagnant throughout the last one hundred years, even with the advent of new paradigms. In addition, this literature review will analyze the current form of zoning and its effect on social and economic structures in America. This report will focus on the use of formbased codes as an alternative to traditional zoning. Finally, this literature 
review will explain how urban design and zoning intersects to combat the problems within a city and to foster the quality of life within it. The area of focus of this report will be on the Arts District in Los Angeles, a unique industrial mixed-use neighborhood. A historical examination of the Arts District will analyze how conventional zoning has addressed the neighborhood's development in the past and how form based codes can address its future.

\section{The Beginning of the City in America}

In 1519, the Spanish conquistador Hernan Cortes arrived at the Aztec city of Tenochtitlan (Chudacoff et al., 2010). What is now known as Mexico City, was once the capital of the Aztec empire and was located in the middle of Lake Texcoco (Diaz, 2012). Tenochtitlan was a city in pre-colonial America that rivaled cities in Spain, Germany, and England. It was characterized by its grand palaces and towering temple pyramids (Chudacoff et al., 2010). The city maintained a robust economy that was supported by a daily marketplace. It moved sixty thousand people's goods and services throughout the region (Chudacoff et al., 2010). Spanish conquistadors were astonished with the ability of the Aztec Empire to develop sophisticated and grandiose cities that contrasted many of the island nations they had first discovered.

"When we saw so many cities and villages built in the water and other great towns on dry land we were amazed and said that it was like the 
enchantments ... on account of the great towers and cues and buildings rising from the water, and all built of masonry. And some of our soldiers even asked whether the things that we saw were not a dream... I do not know how to describe it, seeing things as we did that had never been heard of or seen before, not even dreamed about (Diaz del Castillo, 2012, p. 189)."

But besides the City's grandeur, the City provides one of the earliest examples of organized land uses. Divided into zones and districts, Tenochtitlan, unlike many cities in Europe at the time, developed a sophisticated land use system that included waste disposal. Thousands of men would clean the boulevards daily and haul away garbage on barges through an arrangement of canals throughout the city (Diaz, 2012; Chudacoff et al., 2010). In 1521 however, Cortes overthrew Tenochtitlan and established the Spanish capital on its ruins (Chudacoff et al., 2010). The arrival of the Spanish changed the native Aztec landscape. The conquest of the Aztec and Incan empires by the Spanish colonizers marked the start of urban development in the Americas. Over the next few centuries the Spaniards spread their influence and built many cities in the Americas some of which we know today as St. Augustine, Los Angeles, San Antonio, San Diego, and San Francisco. While early civilizations in the Americas had their own form of land use regulation, the zoning used today has philosophical ties to Europe. 


\section{Western Europe, the Dominant Paradigm}

Western Europe, during the industrial revolution in the eighteenth and nineteenth centuries, was in development since the medieval period. The revolution was a byproduct of gradual technological advancement that began in London, England. Simultaneously, there was progression in agriculture, transportation, and finance, as well as political and industrial developments, and fabricated the revolution in its entirety (Zanden, 2009). The relationship between these sectors, as well as the social, political and cultural factors which shaped the industrial revolution, contributed to the development of land use based on regulation, to develop a more efficient society with continuous economic growth.

Prior to the industrial revolution, eleventh century Europe was relatively underdeveloped in comparison to the prosperous societies of China and the Arab world (Zanden, 2009). At the time, the realm was a compilation of the British Islands, Italy, and the former Carolingian Empire, now France and Germany. Islamic civilization also spanned a much larger area from Southern Spain to China. The population within Europe was much lower, as was the level of urbanization, technology, and education in comparison to the Middle East and China (Zanden, 2009). Within the next four hundred years, Western Europe became the most technologically and economically advanced region in the world. Its rapid rise is attributed to a variety of institutional changes 
such as the intensification of power at the local level, the advent of Christianity as a normative system, the formation of merchant guilds and their contribution to economic efficiency, and the growing demand for literacy which led to further knowledge accumulation (Zanden, 2009). Additionally, population in Europe grew over one hundred percent and more so in England where it grew three hundred percent. These fundamental changes initiated the rapid urbanization and the continued world dominance of Europe into the following centuries.

Europe's preindustrial role in world trade dominance further established the foundation for the industrial revolution (Stearns, 2007). By the sixteenth century the majority of international trade was controlled by Western European nations; England had the largest share. European colonies were a critical element in the success of international trade. The colonies allowed manufacturing to flourish through the provision of low-cost raw materials, which introduced new capital and export opportunities. Prior to the eighteenth century, the majority of manufacturing occurred in the household, with a large labor contingent committed to agriculture (Stearns, 2007). This all changed with the rapid advance of Western European technology, easy access to coal, new financing systems, and a large labor supply that no longer had to work the fields. The advancement of productivity in both manufacturing and agriculture produced a new paradigm for the global economy. By the 
eighteenth century workers were no longer producing goods in their homes or in small shops. Production became industrialized and was the dominant manufacturing system. In the decades preceding the eighteenth century the industrial revolution evolved through a series of processes and structural transformations. It was a product of a variety of interactions between social and economic forces that led to an accumulation of knowledge and the growth of human capital. Cities evolved to comprise of new markets. And as industrialization expanded, so did the need for regulation.

\section{The City in Post-Industrial Europe}

The city of post-industrial Europe was the model that later influenced land-use zoning in twentieth century America. In particular, England and Germany were influential in fostering American land-use regulation (Hirt, 2013). During the medieval period, post-industrial European cities were initially designed by a ruling monarch. The ruling monarch detailed, styled, and designed the appearance of the city (Power, 1989). This approach helped to set the foundation for comprehensive regulation which focused on building structure and physical expression, density, and the location of commercial, industrial, and residential land uses (Power, 1989 \& Logan, 1976). While the visual quality of a city was important in early city planning, the desire to mitigate the problems within a city sparked further regulation. As an example, early building codes such as London's Assize of Buildings that was enacted by the city's first Mayor, Henry Fitzailwin in the twelfth century, was designed to 
alleviate nuisance and safety concerns over fire (Hirt, 2013). The ordinance focused on the types of construction materials used rather than the relationship that the buildings had with one another. Munich, Germany, along with other major European cities also had sophisticated building codes (Hirt, 2013). As time passed after industrialization, population growth and changes in city structure resonated throughout European cities. The increased growth in the poor working class rapidly filled urban industrial jobs. Low wages and destitute living conditions placed the working class into extreme poverty. This led to a slur of social problems throughout Europe, particularly housing (Hall, 2002). Thus, there was a need for land-use based regulation.

"Of the 1,000,000 Londoners estimated by Mr. Booth to be in poverty... practically none are house as well as a provident man provides for his horse. These 200,000 families earning not more than a guinea a week . . and that often irregularly, pay from 3s. to 7s. per week for filthy slum tenements of which a large proportion are absolutely "unfit for habitation," even according to the lax standards of existing sanitary officers. London needs the rebuilding of at least 400,000 rooms to house its poorest citizens (Fabian Society, 1887, p. 7)."

England had a growing problem as the majority of the population was in poverty. Nobility and professional classes saw the lower class as a nuisance, underserving and incapable of rising above their station, with little hope for improvement (Hall, 2002). By 1914, eugenics overlapped with planning and 
was regarded as a shared objective to combat the social problems of the era (Hall, 2002). This led to the publication of various writings that detailed the need for immediate reform in the housing sector throughout England. One of the most influential, which sold 70,000 copies in eight years, was the "Facts for Socialists" written by the Fabian Society in 1887 (Hall, 2002). The Fabian Society emphasized the need to use London's collective power to solve the housing problem. Other journals and press echoed the call for comprehensive reform. And in 1888, the Royal Commission on Housing transferred responsibility for the re-housing of London's impoverished from the Metropolitan Board of Works to the London County Council, a new democratically elected body (Hall, 2002). The Council passed the 1890 Housing of the Working Classes Act, the successor to its 1885 Act. This second Housing Act provided the government with the ability to purchase large areas of land to be redeveloped for tenement housing for the working class. In parallel with London, Berlin, Paris, and New York also experienced extreme population growth and increasing problems in housing densities, land rents, transportation issues, and competition for space. To solve their housing problems the cities followed London's example and built tenement housing for the working class. The tenement housing was only a temporary solution. Housing soon became severely overcrowded, riddled with foul odors and scarce light. This created new social relationships and changed the fabric of urbanized life. 
Germany strongly felt the social and physical changes of the late nineteenth century that it began to focus its attentions, like Britain, on the living conditions of the working class (Logan, 1976). The British and the Americans revered the German city for its order, structure, cleanliness, modernism, and attractiveness. Ironically, the Germans did not share that feeling, but rather saw their cities as poor examples and fraught with social and political instability (Hall, 2002). Even still, the German city was used as a model for cities in Europe and America. Cities like Munich were revered for its building regulations that had been codified since the mid-fifteenth century. It was not until the late 1890 s that regulations and plans, that were originally contrived to regulate individual buildings, were broadened in order to be standardized and prescribed to cover large urban areas (Logan, 1976). Nuisance and housing laws were enveloped into a broader type of regulation: zoning. New zoning followed the trend of comprehensive coverage and greater uniformity in application to a city area. In 1891, the mayor of Frankfurt-am-Main, Franz Adickes, adopted a land-use regulation that divided the city into various districts or zones. Shortly after, the advent of German zoning, as a means to regulate building form and function, quickly spread to England, Switzerland, Scandinavia, and the United States (Hirt, 2013). As German zoning reached America its principles were maintained, although it treated existing uses differently. The Frankfurt Zoning Act created two broad zones that used a 
land use based classification system separated into three districts: residential, industrial, and mixed (Hirt, 2013). Even with three distinct classifications, each zone allowed for more than a single land-use (Hirt, 2013). The mixed-use district provided for a combination of light industrial, commercial, and residential uses (Logan, 1976). Residential districts were not exclusively for residential use but also permitted industries that complied with performance standards. Residential areas did not ban industrial uses but rather had strict bulk requirements for industrial buildings that were often too large to fit (Hirt, 2013). Regulations in Frankfurt showcased one of the first instances of landuse regulation, known today as performance and form-based zoning (Hirt, 2013). The most restrictive of the three districts was the industrial area where most dwelling types were not permitted, except for housing that accommodated personnel who serviced the factories. To further alleviate incompatible uses, Frankfurt required large setbacks for industrial buildings that were located next to residential developments. With high levels of pollutants from industrial manufacturing, separation of residential areas from other activities was of paramount importance. Each country that adopted German zoning created their own regulations that were tailored to fit its needs. The British and Americans constantly examined the model of the German City. Benjamin Marsh from the United States was particularly interested in German zoning and how Germas used it to reform their housing situation. In order to improve upon present conditions, the countries furiously 
exchanged planning ideas. Each country was admired for its own successes. Britain looked towards Germany for town planning, zoning, and urban design, while the Germans looked towards Britain to learn about housing reform, and the French and Americans borrowed ideas from German zoning (Hall, 2002).

\section{Early Land Use Regulation in the United States}

At the turn of the twentieth century, cities viewed land use regulation as a powerful force that could help shape the pattern of urban land use. In 1916, as a direct result of the planning done in Germany, New York City manifested one of the first comprehensive zoning ordinance in the United States. This section will cover the motivation behind its adoption including subsequent litigation and political willpower. Additionally, it will explore the landmark case of Village of Euclid v. Ambler Realty Co in 1926 and the Standard State Zoning Enabling Act of 1923. Finally, it will examine how zoning has shaped the urban fabric over time and how municipalities and the public react to zoning in its present state.

The late nineteenth and early twentieth century experienced a period of challenge as cities began to realize their own economic viability. In parallel with political centralization, cities sought a universal method to regulate land uses (Chadacoff et. al., 2010). At the end of the industrial revolution factories in the United States began to decentralize and move towards the suburbs. Land there was less expensive and there was more space for factories' 
sprawling assembly lines. Because these suburbs were on the periphery of cities they were often adjacent to upper class residential areas which were vehemently opposed to annexation by central cities (Chadacoff et. al., 2010). The goal was to maintain control over objectionable land uses within the suburbs and to remain independent from large cities. Through the influence of corporate and political leaders the suburbs assured its independence and control. However, it created sharp racial, ethnic, and class divisions between cities and suburban areas (Chadacoff et. al., 2010). These planning issues were coupled with the emergence of zoning and included the segregation of social groups and the preservation of residential neighborhoods, the management of urban infrastructure, and the control of municipal finances (Fischler, 1998a). To better understand the various tensions associated with zoning's birth and evolution, this section will explore how the New York City 1916 Zoning Resolution became a paradigm of land use planning and regulation.

New York City of the 1850s had buildings no higher than six stories. With the rapid surge in population growth, advances in technology, and New York's ascension to a national and global city of commerce, it became necessary and feasible to build higher and bulkier buildings. In particular, two technological innovations further developed commercial buildings: the elevator and the structural steel frame. These technologies allowed buildings 
to surge over 300 feet. However, the rapid construction of large buildings fostered issues related to the incompatibility of land uses such as light, ventilation, and public health (Kontokosta, 2013). The loss of light and air to office buildings in the Financial District was a common occurrence due to the construction of large skyscrapers. At the same time, high-end retail stores on Fifth Avenue were negatively impacted by the invasion of large garment factories (Fischler, 1998a). The height of new buildings created new leasable space that the market could not absorb fast enough. As a result, there was a significant drop in rent. Lower-class tenants were able to rent spaces that neighbored higher-class spaces. Other issues included less street lights that caused smaller structures to rely on artificial lighting and ventilation. Additionally, building scales had varied.

These factors created pressures for the development community and business owners who were challenged with unregulated development. In an attempt to regulate the built environment under multiple economic and social forces, New York City brought into existence the country's first Zoning Resolution (Kontokosta, 2013). On July $25^{\text {th }}, 1916$, the New York City Board of Estimate and Apportionment set forth the adoption of an ordinance which regulated land uses within the Greater New York area (Fischler, 1998a). This ordinance set the foundation for other municipalities across the United States to implement land use regulation. The New York City ordinance was the first 
to be adopted, but not the first to be recommended by the Commission of Building Districts and Restriction and of the Heights of Buildings Committee (Fischler, 1998a). The Committee had recommended a similar ordinance three years earlier. The 1916 ordinance was structured by the creation of three distinct districts, each with a different focus of regulation. There was a housing, commercial, and industrial district. Each was organized by five height districts and five more area districts which were much more prescriptive in terms of minimum size of yards, courts, and the maximum percentage of lot coverage (Fischler, 1998a). The ordinance in New York City was not the first use of building regulation. Cities such as Boston, Chicago, and Los Angeles had enacted a form, height, or use regulation prior to the passage of the New York resolution (Kontokosta, 2013). Additionally, fire codes in many cities did not allow for timber buildings within central zones and many housing codes regulated the volume and design of multi-family residences. However, the 1916 ordinance was the first that regulated both use and bulk restrictions within an entire municipality.

New York City set an example for the adoption of zoning regulations by municipalities throughout the United States. In 1923, the Standard State Zoning Enabling Act was widely adopted and was followed by the Standard City Planning Enabling Act, which gave cities the legal ability to create city master plans (Hall, 2002). By 1926, zoning dominated land use regulation and 
had spread to over 425 municipalities (Power, 1989). In the same year, the Supreme Court established zoning as a police power in the landmark case of Village of Euclid et al v. Ambler Realty Co. (Hall, 2002; Knack, 1996). Zoning's validity as a police power won due to the argument that zoning is a lawful form of nuisance control (Knack, 1996). Three years later, more than 754 zoning ordinances had been adopted throughout the United States. While the Euclid case provided legal credibility to planners, this form of zoning, known as traditional or Euclidean, has been labeled as one of the primary mechanisms that supported exclusionary development and urban sprawl (Knack, 1996). Euclidean zoning was intended to keep residential areas separated from the nuisances of industrial activity and has arguably become a tool of separation for more than just land uses (Knack, 1996).

\section{Zoning as an Exclusionary Tool}

As planning evolved it went through a series of phases, one of the earliest was the City Beautiful movement. Similar to zoning, City Beautiful was planning without primary concern for social welfare. The zoning movement has been said to, "profoundly [influence] the subsequent course of American suburban development [and] was, if anything socially exclusionary in its purpose and its impact (Hall, 2002, p. 41)." Zoning began to be used as a police power. Zoning regulations were often used as a tool to keep the lower class, and the services they required, removed from upper class neighborhoods (Talen, 2012). In 1885, in Modesto California, zoning was 
used to segregate. The City of Modesto used their police power to create a laundry free district with the intent to exclude the Chinese (Talen, 2012; Whitnall, 1931). Fifteen years later, in the Southern United States, many cities adopted racial zoning ordinances. These ordinances were designed to allow for a single race to inhabit a particular block while no other racial group was legally allowed to move in. In the 1917 trial, Buchanan v. Warley, the Supreme Court ruled against racial zoning and deemed it unconstitutional (Talen, 2012). However, some municipalities discovered ways to circumvent the law. Cities would zone industrial areas into neighborhoods that they knew to be predominantly African American in order to decrease the land values in the vicinity. In Glynn County, Georgia, alleys were not allowed to be built adjacent to lots with a depth of 120 feet in order to deter additional rear units, often connected with poor African Americans (Talen, 2012).

The separation of land uses at the turn of the twentieth century has failed to accomplish many of its original goals (Fischler, 1998b). Zoning and subdivision regulation were designed "to segregate inconsistent uses, prevent congestion, and provide for the economical provision of public services (Fischler, 1998b, p.676)." The primary idea of zoning, according to William Munro, the leader of the National Municipal League, was to make public administration more orderly (Fischler, 1998b). Racial zoning was distractive and played a detrimental role in zoning's evolution. However, recently zoning 
has become a positive tool that has the ability to shape the urban fabric as well as social, environmental, economical factors.

\section{Form-Based Codes: Place Based Land Regulation}

Where traditional zoning of the past century failed to address a holistic approach in urban planning, and instead produced disconnected communities, form-based codes promote place-based planning. The Formbased Code Institute defines form-based codes as a type of land use regulation that focuses on the creation of predictable development patterns and high-quality public space. Form-based codes require all development to be cohesive so that it fosters a place envisioned by the community. A formbased code defines the physical form that identifies and emphasizes an urban hierarchy, rather than focusing on the separation of land uses found in conventional zoning codes. A form-based code is regulatory and not advisory. Furthermore, form-based codes help implement the vision of a community. Since diversity is such an important factor of a successful place, form-based codes mix people with uses and activities to create creative and vibrant cities and neighborhoods (Talen, 2012).

Form-based codes are governed by the SmartCode, developed by Andres Duany and Elizabeth Plater-Zyberk. The SmartCode is used to establish an urban-to-rural transect-based approach to organize land use regulation. The urban-to-rural transect defines six Transect Zones (T-zones) that range from 
the most rural of intensities to the most urban. The classification of each zone within the Transect hierarchy is primarily determined by the building intensity, character, form, type of place, and secondly, by diversity of uses.

\section{Los Angeles - Land-Use Evolution and History}

In 1781 the Spanish colonial government established the area known today as Los Angeles under the name El Pueblo de Nuestra Senora la Reina de los Angeles. The city fell under Spanish Laws of the Indies, that detailed development, administration, and social issues (Gish, 2012). These regulations shaped the city as it changed hands to the Mexican government in 1821, and later the United States in 1848.

By the 1900s Los Angeles was a rapidly changing city. A population boom, was coupled with economic and industrial development. Similar to New York, Los Angeles experienced crowded tenements riddled with congestions and poverty, and filled with poor working class families (Gish, 2012). The City Beautiful movement dominated early planning. Comprehensive planning began for Los Angeles with the establishment of the Los Angeles County Regional Planning Commission (LACRPC) in 1922. Plans began to be produced that focused on challenges facing the region. As an example, congestion and connectivity, still contentious issues in the present, needed to be alleviated thus the city hired Frederick Law Olmsted Jr to produce the 1924 Major Traffic Street Plan. Planning for the city continued to evolve as the 
population increased and development spread further out from the central hub.

Los Angeles was a city dominated by the single-family home. In 1909 the city prohibited any businesses from locating within residential areas and sequestered all business to 25 industrial districts (Whittemore, 2012). With the establishment of the City Planning Commission in 1920 by 1921 the City Council created five different zoning designations. The city followed Clarence Perry's neighborhood unit idea where single family homes were separated from commercial activities and high density housing was located close to major arterials (Whittemore). Zoning up until the 1960s was on the side of homeowners and developers. In 1972 the planning department created Community Plans that allowed them to review specific areas and challenge unchecked growth by developers. Even with the establishment of community plans homeowners still dominated land use policy. By 1999 the city established neighborhood councils as part of a charter reform in an effort to decentralize planning review. With fears that the neighborhood councils would become too exclusive they were turned into advisory liaisons to reduce their immediate power but still allow them to have influence (Whittemore, 2012). Los Angeles land use policies continue to evolve as the various policy influences change with time. Recently, there has been a shift in homeowner influence that has allowed Los Angeles to experience urban infill and high- 
density development. This change is attributed to the dynamism of politics, environmental and social issues, economic forces, and technology that will continue to shape Los Angeles and all cities as they face urban problems in the coming future. 


\section{CHAPTER 3: RESEARCH QUESTIONS AND METHODOLOGY.}




\section{Introduction}

The following is the methodology used for the creation of the Arts District Form-Based Code. This project utilizes a literature review that details the history of zoning, the advent of form-based codes as an alternative to conventional zoning, and the history of land use in Los Angeles. Numerous site visits, data collection, review of documents, and interviews were used to develop the Regulating Plan.

\section{Research Question(s)}

1. What defines the Arts District as a unique place?

2. How does industry play a role in the Arts District's history?

3. How has land use regulation shaped the development of the Arts District?

4. What are the roles of form-based codes in land use regulation?

\section{Method 1 - Site Visits}

For the formation of the Form-Based Code attendance at community meetings, discussions, and walking tours were used to understand the Arts District's unique character and architectural history and how these factors will determine its identity in the near future. There were two initial site visits followed subsequently by further field research between October 2013 and June 2014. 
On October 5, 2013 the Southern California Institute of Architecture hosted the Los Angeles Region Planning History Group: Colloquium IX - The Evolution of Industrial Mixed Use in Downtown LA: Conflict of Mutual Accommodation. The purpose of this visit was to gain knowledge of the history of the Arts District and gather information on its rapidly-changing industrial neighborhood. A panel of speakers discussed Los Angeles' industrial legacy, present and future policy challenges, and potential planning policies for industrial land. The speakers included Alan Bell, Deputy Director of Planning with the City of Los Angeles, Yuval Bar-Zemer, Principal of Linear City Development, Donald Spivack the former Deputy Administrator and Deputy Chief of Operation for the Community Redevelopment Agency of Los Angeles, and Pouya Abdi, Principal of Parallel Acquisitions and Holdings. Transcribed notes can be reviewed in the appendix.

On November 10, 2013 the Los Angeles Conservancy hosted a Walking Tour of the Arts District entitled Arts District: History and Architecture in Downtown L.A. The purpose of this visit was to gain an understanding of the area's historical architecture, building form, land use, culture, and pedestrian accessibility. Information gathered during these site visits was used as part of the site analysis and Regulating Plan. 


\section{Method 2 - Data Collection}

Data for the Regulating Plan was prepared and collected from various sources that include Mapshare: UCLA's Spatial Data Repository, Los Angeles County GIS Data Portal, METRO: Developer Metro's Official Blog of Transit Data and Technology, the United States 2010 Census, and the Los Angeles Department of Transportation Transit Services. Data was later synthesized into multiple maps, in order to analyze circulation and transit patterns, inventory recent development and adaptive reuse projects, and analyze the building fabric.

A formal session on October $6^{\text {th }}, 2013$ Cal APA Conference in Visalia titled: Form Based Zoning Grows Up by Don Elliott, FAICP, Clarion Associates was attended to gather information on the role of form-based codes in land use regulation. Transcribed notes can be viewed in the appendix.

\section{Method 3- Review of Relevant Documents}

The following plans and documents were reviewed, used to complete the site analysis, and used to form the Regulating Plan: City of Los Angeles General Plan, Central City North Community Plan, Los Angeles' Industrial Land: Sustaining a Dynamic City Economy, Central Industrial Redevelopment Project Area: Five Year Implementation Plan, Cleantech Corridor Los Angeles CA: A Vision for the Evolution of an Industrial Corridor, Alameda: ILUP Geographically Specific Directions, Uncommon Ground: Visions for the LA 
Arts District by Residents of the LA Arts District, Uncommon Ground III: Imaginings a Future for the Arts District, The Arts District: History and Architecture in Downtown LA by the Los Angeles Conservancy, SmartCode Version 9.2, San Francisco Planning Department Parklet Manual, City of Los Angeles Green Streets and Green Alleys Design Guidelines and Standards, Complete Streets Thoroughfare Assemblies SmartCode Module, and Bicycling SmartCode Module.

\section{Method 4 - Planner Interviews}

A series of interviews were conducted to gather in-depth information on specific problems and concerns associated with the Arts District, development, form-based codes, the real estate market, and industrial land use. Transcribed notes can be viewed in the appendix. 
CHAPTER 4: FINDINGS 
Data analyzed provided direction for the formation of the Regulating Plan.

\section{Arts District: History, Industry, and Land Use}

The area where the Arts District is now located was once characterized by acres of vineyards founded by the French immigrant Jean-Louis Vignes in the mid 1800s. At the end of the nineteenth century, the Southern Pacific Railroad, and later the Atchison, Topeka and Santa Fe Railroads arrived in Los Angeles. By 1905, the Union Pacific Railroad was built. It solidified the Arts District as the industrial, transportation, and manufacturing center for Los Angeles. Due to the needs of the three major transcontinental railroads, the building stock included of rail depots, transportation buildings, warehouses, and rail yards.

In the late 1880 s the Arts District supported several residential neighborhoods. By 1922 the City of Los Angeles rezoned the area for industrial uses that sanctioned it as an industrial and manufacturing center. After World War II the Arts District struggled to compete with neighboring cities that could better accommodate the needs of modern industries. The Arts District's small parcel sizes and narrow streets were not ideal for the emerging trucking industry and larger manufacturing plants. The infrastructure began to deteriorate. Many buildings were left vacant and dilapidated as companies moved to neighboring cities such as Vernon and the City of Commerce. 
In the 1970s, artists who were priced out of the Art scene in Hollywood and Venice began to illegally move into the area. The vacant warehouses were ideal for live/work studios and were sold and leased to artists at below market-rates. In 1981, the City acknowledged this migration into the Arts District and legalized the residential use of former industrial buildings through the Artist-in-Residence (AIR) program. In the early 1990s, the Arts District became the official name of the area as a means of marketing it after the economic recession.

By the late 1990s, the Arts District had become a culturally rich and unique place to live. It experienced a wave of development with the landmark 1999 passage of the Adaptive Reuse Ordinance (ARO) that allowed the conversion of pre-1974 commercial and industrial buildings into residential buildings for non-artists. Today, the Arts District attracts artists, developers, residents, and a wide variety of professional firms while it continues to have a solid industrial base. Recently, there has been commercial and residential development, built from the ground up, that lacks consistency with the character and scale of the existing building stock. 
Key themes discovered in data collection and the literature review are organized as strategies below:

- Develop the Arts District into a cohesive community with a clear development pattern.

- Ensure that the Arts District boundary is large enough to encompass future growth, but small enough to maintain its unique industrial and artistic character.

- Maintain the District's unique character and sense of place that it gains from its architecturally distinctive buildings and industrial urban structure.

- Incubate high tech business development through the utilization of relatively small parcel size and prime location near Union Station, local universities (Cal Tech, UCLA, USC etc.), services, and other institutions. (CRLA)

- Catalyze a Cleantech corridor by capitalizing on historic infrastructure and the flexible nature of building stock.

- Focus on the creation of more open and green space in residential nodes that includes parklets, pocket parks, community gardens, and tree planting; connect those resources with the Los Angeles River Revitalization Master Plan. 
- Improve circulation through enhanced pedestrian infrastructure, river access, the creation of thru-block pathways, dedicated bike lanes, public transit, and parking.

- Enhance the arts culture of the District through more exhibition venues, public arts funding, historical walking tours, and a community art workspace.

- Protect Industrial land uses and industrial jobs.

- Encourage future development to be adaptive reuse, green building design, and focus on live/work units, affordable housing, and AIR housing.

- Apply low-impact development standards that include green streets, stormwater management, green roofs, and renewable energy sources. Enhance the arts culture of the District through more exhibition venues, public arts funding, historical walking tours, and a community art workspace.

- Protect Industrial land uses and industrial jobs.

- Encourage future development to be adaptive reuse, green building design, and focus on live/work units, affordable housing, and AIR housing.

- Apply low-impact development standards that include green streets, stormwater management, green roofs, and renewable energy sources. 


\section{BIBLIOGRAPHY}


Bettman, A. (1924). Constitutionality of Zoning. Harvard Law Review, 37(7), 42-67.

Brasuell, James. (2013). Barker Block Moving on Arts District's Only New For-Sale Units. Curbed: Los Angeles. Retrieved from:

http://la.curbed.com/archives/2013/04/barker_block_moving_on_arts_districts _only_new_forsale_units.php.

Chudacoff, H. P., Smith, J. E., \& Baldwin, P. C. (2010). The evolution of American urban society. Upper Saddle River, NJ: Prentice Hall.

City of San Francisco Planning Department. (2013). San Francisco Parklet Manuel.

Community Redevelopment Agency of the City of Los Angeles California. (2007). Central Industrial Redevelopment Project Area: Five Year Implementation Plan 2008-2012.

Community Redevelopment Agency of the City of Los Angeles California. (2007). Los Angeles' Industrial Land: Sustaining a Dynamic City Economy.

Coldwell Banker Richard Ellis Global Research and Consulting. (2014). Greater Los Angeles Industrial Market View.

Crane, J. (1931). Progress in the science of zoning. The Annals of the American Academy of Political and Social Science, 155(2), 194-201.

Crawford, P. C, Parolek, D. G. \&., Parolek, K. (2008). Form-based codes: A guide for planners, urban designers, municipalities, and developers. Hoboken, N.J: J. Wiley \& Sons.

Department of City Planning and the Community Redevelopment Agency of the City of Los Angeles. (2007). Los Angeles' Industrial Land: Sustaining A Dynamic City Economy.

Development, and White Privilege. Athens: University of Georgia Press.

Diaz del Castillo, B., Burke, J., Humphrey, T. (2012) The True History of the Conquest of New Spain. Indianapolis, Indiana: Hackett Pub. Co.

Douglas Cazaux Sackman (2005). Orange Empire: California and the Fruits of Eden. Berkeley: University of California Press. 
Duany Plater-Zyberk \& Company, Chellman, C., Hall, R., Swift, P. (Retrieved 2014). Complete Streets Module.

Duany Plater-Zyberk \& Company. (2003). SmartCode Version 9.2.

Duany Plater-Zyberk \& Company. (Retrieved 2014). Thoroughfare Standards Replacement SmartCode Module.

Duany, A., Plater-Zyberk, E., \& Speck, J. (2000). Suburban Nation: The Rise of Sprawl and the Decline of the American Dream. New York: North Point Press.

Fabian Society (1887). Facts for Socialists: From the Political Economists and Statisticians. London: Fabian Society.

Fischler, R. (1998a). The metropolitan dimension of early zoning: revisiting the 1916 New York City ordinance. Journal of the American Planning Association, 64(2), 170-188.

Fischler, R. (1998b). Health, safety, and the general welfare: markets, politics, and social science in early land-use regulation and community design. Journal of Urban History, 24(6), 675-719.

Fischel, W. A. (2003). An economic history of zoning and a cure for its exclusionary effects. Rochester: doi:http://dx.doi.org/10.2139/ssrn.461140.

Fredland, Daniel R. (1980). Environmental Performance Zoning: An Emerging Trend? The Urban Lawyer , Vol. 12, No. 4 pp. 678-699Published by: American Bar Association Article Stable URL: http://www.jstor.org/stable/27890969.

Gish, Todd (2012). Challenging the Myth of an Unplanned Los Angeles. In Sloane, D. C. Planning Los Angeles. Chicago: American Planning Association.

Hall, Peter (2002). Cities of Tomorrow. Malden, MA: Backwell Publishing.

Hirt, S. (2013). Home, sweet home: American residential zoning in comparative perspective. Journal of Planning Education and Research, 33(3), 292-309.

Hise, G. (1993). Home building and industrial decentralization in Los Angeles: The roots of the postwar urban region. Journal of Urban History, 19(2), 95125. 
Hise, G. (2009). Industry, political alliances and the regulation of urban space in Los Angeles. Urban History, 36(3), 473-497.

Hise, G. (1993). Home building and industrial decentralization in Los Angeles. Journal of Urban History, 19(2), 95.

Historic Cultural Neighborhood Council. (2006). Uncommon Ground I: Visions for the LA Arts District.

Historic Cultural Neighborhood Council. (2012). Uncommon Ground III: Imagining a Future for the Arts District.

Howland, M. (2011). Planning for industry in a post-industrial world:

Assessing industrial land in a suburban economy. Journal of the American Planning Association, 77(1), 39-53.

Jaime Correa and Associates, with Maria Bendfeldt and Jennifer Hamilton. (Retrieved 2014). Renewable Resources SmartCode Module.

Knack, R. E. (1996). Return to euclid. Planning, 62(11), 4. Retrieved from http://ezproxy.lib.calpoly.edu/login?url=http://search.proquest.com/docview/20 6702122 ? accountid=10362.

Kontokosta, C. E. (2013). Tall Buildings and Urban Expansion: Tracing the Evolution of Zoning in the United States. Leadership \& Management in Engineering, 13(3), 190-198. doi:10.1061/(ASCE)LM.1943-5630.0000226.

Laura R. Barraclough (2011). Making the San Fernando Valley: Rural Landscapes, Urban.

Lee III, E. G. (2001). Symposium on the Seventy-Firth Anniversary of Village of Euclid V. Ambler Realty Co. Case Western Reserve Law Review, 51(4), 593.

Logan, T. H. (1976). The Americanization of German Zoning. Journal of the American Institute of Planners, 42(4), 377-385.

Los Angeles Conservancy. (2013). The Arts District: History and Architecture in Downtown LA.

Los Angeles County Bicycle Coalition. (2013). Bicycle Parking Ordinances: Examples from the United States. 
Los Angeles Department of City Planning. (2000). City of Los Angeles General Plan, Central City North Community Plan.

Los Angeles Department of City Planning. (2014). General Plan Structure: Summary of the General Plan Elements.

Los Angeles Department of City Planning. (2006). Generalized Summary of Zoning Regulations City of Los Angeles.

Los Angeles Department of City Planning. (2007). Interim Procedures Regarding Applications fot Residential Projects on Industrial Zoned Property Determined to Be No Longer Viable For Industrial Use.

Los Angeles Daily Journal. (1981). Joint living and work Quarters Amendment. Ordinance No. 155843.

Los Angeles Department of City Planning. (2010). Joint Living and Work Quarters Ordinance: 181133.

Los Angeles Department of City Planning. (2013). Mural Ordinance: 182706.

Los Angeles Department of City Planning. (2008) Case No. CPC-2008-3417GPA Plan Amendment.

Los Angeles Department of City Planning. (2009). Transmittal to City Council. Case No. CPC-2009-1771-CA Joint Living and Work Quarters.

Los Angeles Department of City Planning Recommendation Report. (2008). General Plan Amendment to Arts District Boundary. Case No. CPC-20083417-GPA.

Los Angeles Department of Public Works. (2009). Green Streets and Green Alleys Design Guidelines Standards.

Lydon, M., Adelson, Z., Garcia, T. (2008). Bicycling SmartCode Module.

Maantay, J. (2001). Zoning, equality, and public health. American Journal of Public Health, 91(7), 1033-1041.

Power, G. (1989). The advent of zoning. Planning Perspectives: PP, 4(1), 113. 
Richard J. Orsi (2005). Sunset Limited: The Southern Pacific Railroad and the Development of the American West, 1850-1930. Berkeley: University of California Press.

Shane, D. (2005). Recombinant Urbanism: Conceptual Modeling in Architecture, Urban Design, and City Theory. Chichester: Wiley-Academy.

Schilling, J., \& Linton, L. (2005). The public health roots of zoning. American Journal of Preventive Medicine, 28(2), 96-104.

Scott, A. (1993). The new southern Californian economy: Pathways to industrial resurgence. Economic Development Quarterly, 7(3), 296-309.

Shoked, N. (2011). The reinvention of ownership: The embrace of residential zoning and the modern populist reading of property. Yale Journal on Regulation, 28(1), 91-149.

Sitton, Tom. (2010). Grand Ventures: The Banning Family and the Shaping of Southern California. San Marino, CA: Huntington Library Press.

Sitton, Tom. (2005). Los Angeles Transformed: Fletcher Bowron's Urban Reform Revival, 1938-1953. Albuquerque: University of New Mexico Press.

Stearns, P. (2007). The Industrial Revolution in World History. Boulder, Colo.: Westview Press.

Talen, E. (2009). Design by the rules: The historical underpinnings of formbased codes. Journal of the American Planning Association, 75(2), 144-160.

Urban Land Institute. (2010). Cleantech Corridor Los Angeles, California. An Advisory Services Program Report.

Vankin, Deborah. (2013). Downtown L.A.'s 'Mural Mayor' Daniel Lahoda draws praise, controversy. Los Angeles Times. Retrieved from:

http://articles.latimes.com/2013/jul/05/entertainment/la-et-cm-daniel-lahodamurals-main-bar.

Vincent, Roger. (2013). Two vacant L.A. warehouses to be replaced with mixed-use complex. Los Angeles Times. Retrieved from: http://www.latimes.com/business/realestate/la-fi-megatoys-apartments20130926,0,2429622.story\#axzz2kZVXspo7. 
Wachs, M. (1984). Autos, transit, and the sprawl of Los Angeles: the 1920s. Journal of The American Planning Association, 50(3), 297.

Whitnall, Gordon. (1931). History of Zoning. Annals of the American Academy of Political and Social Science, Vol. 155, Part 2: Zoning in the United States (May, 1931), pp. 1-14.

Whittemore, Andrew (2012). One Hundred Years of Land-Use Regulation. In Sloane, D. C. Planning Los Angeles. Chicago: American Planning Association.

Woodward, K. (2013). Form over use: Form-based codes and the challenge of existing development. Notre Dame Law Review, 88(5), 2627-2653.

Zanden, J. (2009). The Long Road to the Industrial Revolution: The European Economy in a Global Perspective, 1000-1800. Leiden: Brill. 


\section{APPENDICIES}




\section{Appendix A: Primary Researcher Notes}

Transcribed Notes: Colloquium IX - The Evolution of Industrial Mixed Use in Downtown LA: Conflict of Mutual Accommodation Date: Saturday, October 5, 2013

Historic Overview:

- Johnson Tract 1871, Lagardo vineyard, Arthur Tract 1893, Arthur J Shafer

- LA and San Pedro Independence

- Railroad 1875, LA and IRR Depot Towers

- Southern Pacific Arcade Depot

- La Grade Depot AT and SF Railroad

- LA Railway $7^{\text {th }}$ and Central Ave

- Industrial Tract

- 1922 City Planning zoned out all housing in the area, created worlds largest office park

- Trucks had trouble turning onto Alameda

- Lots were middle class housing

- Vernon and City of Commerce had better railroad access

- Al's Bar, American Hotel

- 3 Distinct Retail Nodes Urth Café, Barker Block and Traction Avenue

- River draw, creative vibrant, up and coming

Alan Bell, Deputy Director of Planning, City of Los Angeles Said:

- 1981 live work space legalized housing for artists who produced art

- Over time wholesale conversions were taken over

- Case by case basis for conversion of land only fact of that application

- Covenant not enforced

- Not as expansive as west Alameda

- No place quite like the arts district

- Unique synergy, reuse, historic buildings, location, art river park

- Opportunity extraordinary value, can build social capital

- Artist ethos, sense of place

- Case by case live work approvals

- Advancing next generation of community plan

- Finding for central city north plan and recode LA

- New zoning concepts, new planning tools, hybrid zones, performance zoning

- Visionary, stakeholders, implementation of new zoning, opportunity to start fresh

- Parking credits cannot be used tangled up by covenant need parking managed on a district basis and not lot by lot 
Yuval Bar-Zemer, Principal, Linear City Development \& Resident of the Arts District, Said:

- Diametrically opposed to artist created momentum forcing city to legitimize it

- Who is living, why what do they do?

- Live/work has the ability to work from home and create more jobs in the area

- Arts District is in danger it's a victim of its own success

- Intention is good, timing difficult ignored economic recessions

- New development will switch character of neighborhood

- Planner industrial land, do not permit ground up construction, game of time

- Arbor Study, flexibility the unpredictable to happen, live/work and industry, ability to switch between industrial and residential within a single building/area

- Open space is needed

- Structural integrity, for live/work/creative space, outdates

- Office, Cleantech

- Infrastructure should allow for multiple uses over time

- Requirements vs reality, what is practical

- Realize that eh car is NOT the main system of transportation, Bike are

Donald Spivack, Professor USC, former Deputy Administrator and Deputy Chief Operations for the Community Redevelopment Agency of Los Angeles (CRA/LA) Said:

- Arts from industrial district

- Post WWII rail vertically, manufacturing became horizontal and truck based

- Businesses moved to transportation corridor

- Residential space is $1 / 3$ cost for developers and generates the same rental/cost as the historical core of Los Angeles

- Economic destination LA river as the new Green Spine a new set of lungs, Boyle Heights, China Town

- Arts District only a portion of the industrial area of Los Angeles

- Less auto dependent, flexibility, Cleantech to develop transit vehicles, solar panels etc.

Pouya Abdi, Principal, Parallel Acquisitions and Holdings, Said:

- Demand for business, retail

- Store brings artist, employees, construction, positive economic activity, cash flows

- Similar to Robertson tenants increased became a culture of its own unique character

- Arts District characterized by 1930 s brick building, special place 
- Market will tell which businesses survive

- Parking issues, need for additional parking

- Maintain network

- Change vs continuity and historic preservation

Transcribed Notes: Cal APA Conference in Visalia Sunday Session: Form Based Zoning Grows Up Date: October $6^{\text {th }}, 2013$

Don Elliott, FAICP, Clarion Associates Said:

- Form is the most important factor in a FBC, followed by process, and then uses

- 6 Questions before preparing regulating plan

- will form controls cover whole town or just particular areas

o if it applies to only a specific area is there a plan for that area

- regulations for? Greenfields

- contextual or prescriptive

- type of buildings on location do not make current owners non conforming

- how to treat existing businesses

- Myth: traditional zoning based on use separation, false its about regulating land uses, mixing is allowed

- Myth : Form based zoning ignores uses, false uses are regulated just more lightly, they are secondary to form

- $\mathrm{FBCl}$ elements: building form standards, building type standards, frontage type standards, public space standards (streetscapes and open space), block and subdivision standards, regulating plan (mix of buildings)

- urban world transect, smartcode template approach

- ten years ago no one knew what FBCs were now they are everywhere

- NY 1916 Euclid (nuisances)

- Zoning evolved from prevention, to uses district, to flexible, to performance zoning PUDS and later form based

- FBCs help talk about building and not uses

- Predictability, flexibility, post war use based, performance then PUDs then form based

- FBC goals sustainability, demographic change housing affordability, historic preservation, emissions energy conservation, walkability public health, reduced VMTs 


\section{Appendix B: Interview Notes}

Interview: Professor Donald Spivack, former Deputy Chief Administrative Officer for the Community Redevelopment Agency of the City of Los Angeles Interview Date: January 10, 2014

\section{Professor Spivack Said:}

- Brief overview of the history of the Arts District how it evolved from an industrial railroad district (1870s) and later after WWII the advent of trucks and mechanized factories shaped the building types to be no more than $1 / 2$ stories in height with some $6 / 7$ story buildings as well. The artists began moving in, in the mid 80 s by an amendment to the zoning ordinance that allowed for people to move into converted buildings and live/work. Only allowed for converted units not stand alone residential or new construction (adaptive reuse). In 2000 modification to the community plan to have a continuation of the conversions, which at the time didn't have an adverse impact on the industrial uses yet. This happened at the same time as the adaptive reuse ordinance for commercial buildings.

- Developers first developed $4^{\text {th }}$ and Spring by Tom Gillmore, very successful. Developers than began to look towards multistory buildings just outside of the Arts District. Acquired additional buildings into loft/live/work buildings. This was the first penetration of residential into industrial areas. Pressure on business owners to start moving out because of complaints of nuisances. The City at the time was very lenient with the findings for a conversion. A building was deemed acceptable if it would not adversely effect its surrounding and if the site was not currently being used actively. No one looked at the geography of the boundary. Finally, they decided to not allow rampant development.

- They realized that they were not creating a cohesive community, allowed development anywhere an individual acquired property, created conflict of scarce public resources, no schools, no parks, conflict with the general plan

- The position was that if there was a clear and defined boundary big enough to encompass growth but small enough so that it was cohesive and also protect the area that could continue to remain an industrial district, this was in parallel to the river plan and the clean tech corridor plan

- We knew that older industrial areas could not compete with new larger facilities

- Start up business, high tech businesses that can be started on relatively small properties and are near to services would contribute to 
the type of development pattern that is near the river corridor close to union station close to transit, close to medical institutions and local colleges, JPL, UCLA, USC and other institutions that are into high tech activity, making Arts District ideal for start up businesses and living environment for an entrepreneur, get in ahead of it beat out the discovery of silicon beach Venice beach to create a core in dtla

- ULI did an analysis of the corridor said that it runs from China town down to Vernon oriented around union station, with the Artist District as the center of the creative area, the industrial for start ups and cleantech and additional manufacturing towards the southern end of the district, the rest can function with small production activity and easy distribution graphic oriented work medical device creation can be done with the current building stock and using the current buildings for high tech use

- Set boundary for live/work that fits with the other uses, the need for an industrial zone

- Telling staff to violate the general plan through the displacement of industries, jobs, industries pay taxes not residential

- Building value is increased in the short run but then flat lines due to prop 13

- Real estate rises at about $2 \%$ per year in values, however at the same time people also demand more public services fire, police, parks etc, not carried by the $2 \%$ growth

- Makes sense to look at the area right now and perhaps expand the boundary around mateo st. urban radish on imperial, frontage of retail activity on $7^{\text {th }}$ now on santa fe large clustering of loft buildings, argument over conversion, NIMBY case of fire station to bar, south of $7^{\text {th }}$ street boundary should be extended

- North end has a regional connector TOD site, residential development done by general plan amendment

- Potential for the area surrounding the pickle buildings

- Clear boundary for the area, amount of stuff entitled is three times the population projection from the census 1200 to 1800

- The amount of development underway is three times that number

- Brand the area, issue with the cleantech, idea of creative arts $v$ cleantech and what sets it apart, stock of older buildings that gives it a physical feel, proximity to river, proximity to dtla, similar to tech town in Detroit, waterfront in Boston

- Industrial isn't gone

- Industry goes away they lose jobs but people stay, workers are transit dependent

- Potential regulations from performance metrics: no hazards and no noxious uses limited use times retain job producing land 
- Public benefit requirement could be to allow the market to work with a FAR of 1:2, tiered zoning min below market, density bonus, public open space, incentive private access, extending decks

- Accommodate public infrastructure by site layout of circulation divert industrial activity to certain streets, minimum standard for entire area (street systems), green belt, setback requirement for commercial outdoor dining, storm drain problems, access power, reduce trakages, parks under bridges

- Modify zoning pattern or write limited use manufacturing, rewrite $\mathrm{CM}$ and Manufacturing

- Specific plan zones unique too complicated if not add an overlay

- Rewrite industrial land use policy

Interview: Pouya Abdi, Principal at Parallel Acquisitions \& Holdings Interview Date: January 10, 2014

Pouta Abdi Said:

- In February 2012 purchased a 1 story brick manufacturing building with the goal to convert it to retail + restaurant space

- Interested in similar buildings in the area

- Improve the process of issuing permits, currently inefficient, should have a single plan checker responsible for project prior to submittal

- Should have more incentives for developers, state enterprise rules, development agreements "Christmas bag full of incentives"

- For example: take away the FAR requirements if developer willingly provides more parking, ie. More parking allows for higher FAR

- CUP process

- Restaurants, retail nuisance complaints

- Facilitate natural market

- Allow for developers to convert real estate, adaptive reuse to make the process legal

- Opposed to more restriction

- Allow developers to buy and convert at will

- $7^{\text {th }}$ North and Below $2^{\text {nd }}$ high demand, about $\$ 100-\$ 300$ per square foot? more sophisticated people

- Walls taken down

- Incentives in the regulation, $10 \mathrm{k} \mathrm{sq} \mathrm{ft} \mathrm{take} \mathrm{away} 1 \mathrm{k} \mathrm{sq} \mathrm{ft} \mathrm{for} \mathrm{ground}$ floor parking and allow for $14 \mathrm{k} \mathrm{sq} \mathrm{ft}$ as incentive for building parking

- What Parallel does:

- Acquire properties that have culture, walk and explore clothing store, comfortable parking, look for who is there 
- run the numbers to see what the current market rents are, and see what adjacent buildings are selling/leasing for 
Appendix C: Arts District Form-Based Code 
city of los angelesarts district FORM-BASED CODE

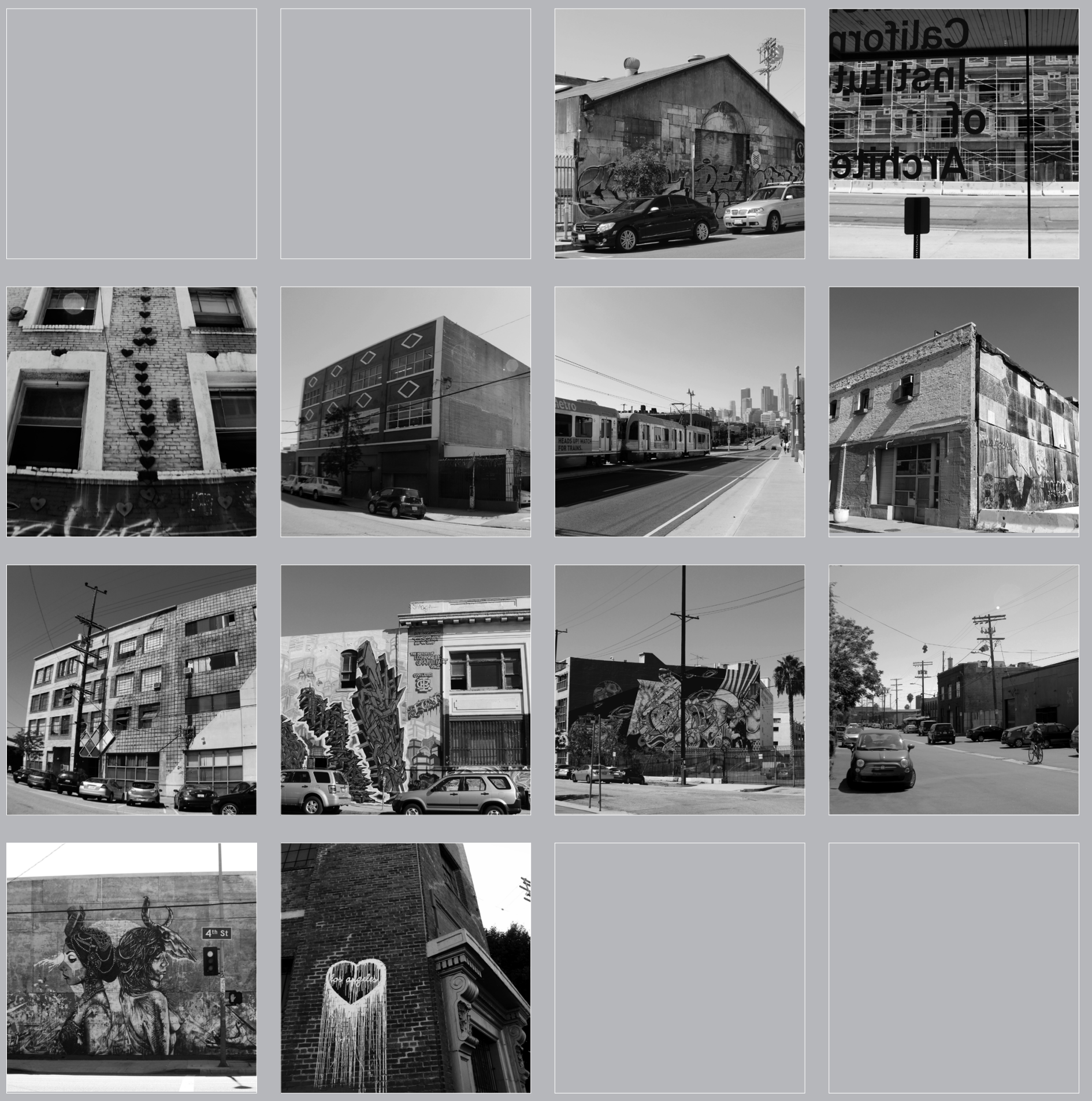



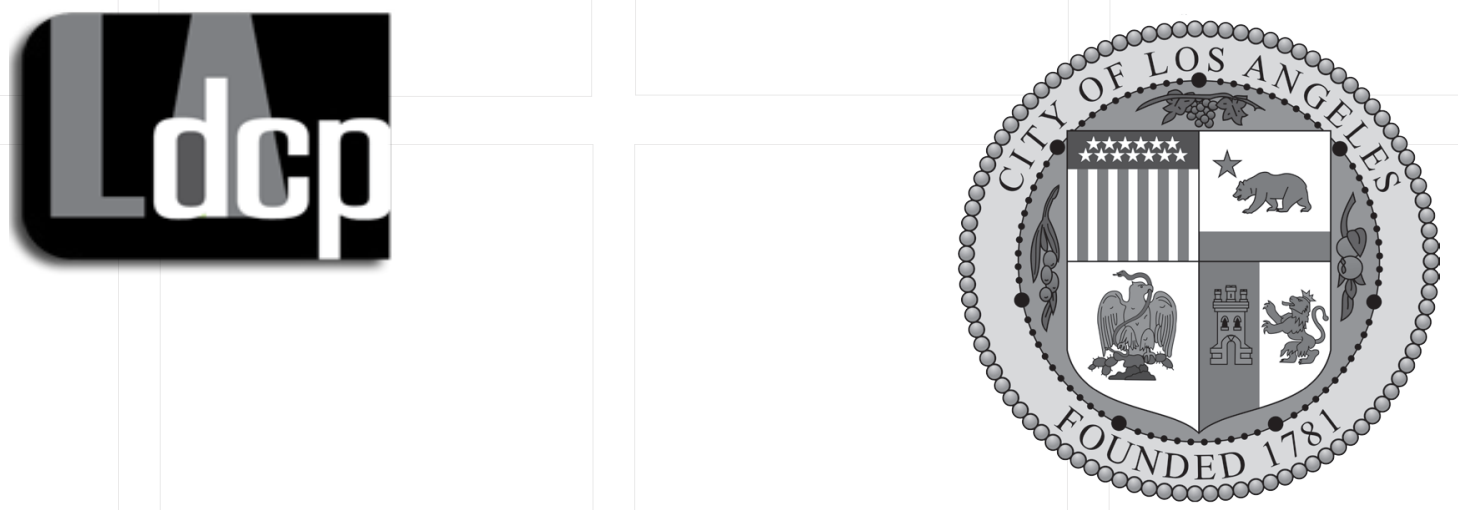

Prepared by:

Ryan Banuelos

$\underline{\text { Advisor }}$

Professor Umut Toker

Committee Members

Professor William Siembieda

Bryan Eck, Planning Associate LADCP

Acknowledgments

Professor Donald Spivack

Pouya Abdi

Athleen Pascual 


\section{Contents}

chapter 1

Introduction

chapter 2

Site Analysis and Background Summary....

chapter 3

Form-Based Code.

chapter 4

Public Space Standards and Design Guidelines.

61

Conclusion.

82

References 85 


\section{Figures}

Figure 1. Regional Map of Los Angeles ............................................ 9

Figure 2. Figure Ground and Building Fabric ................................ 20

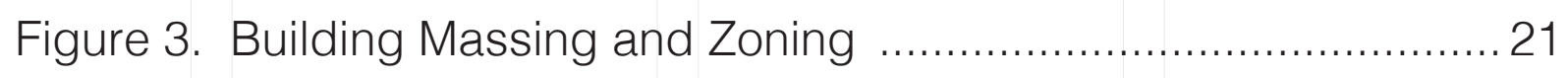

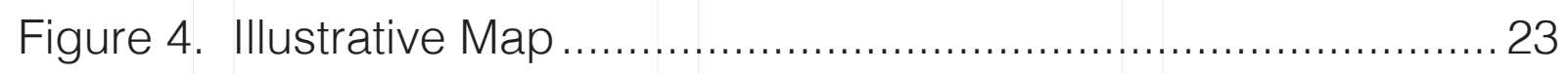

Figure 5. 2010 Arts District Inflow Job Characteristics ........................2 24

Figure 6. 2010 Top 8 Jobs in Arts District by NAICS Industry ............ 25

Figure 7. Street Designations Map .................................................. 27

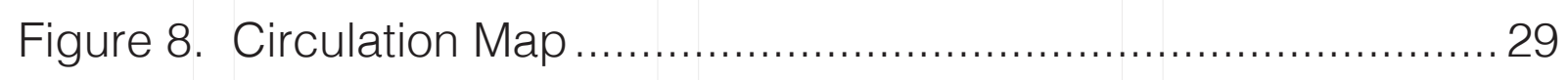

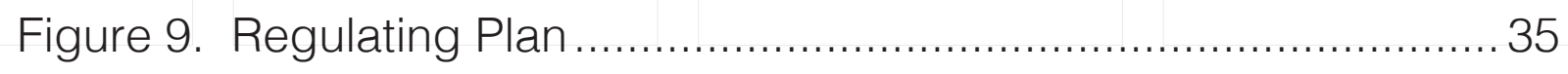



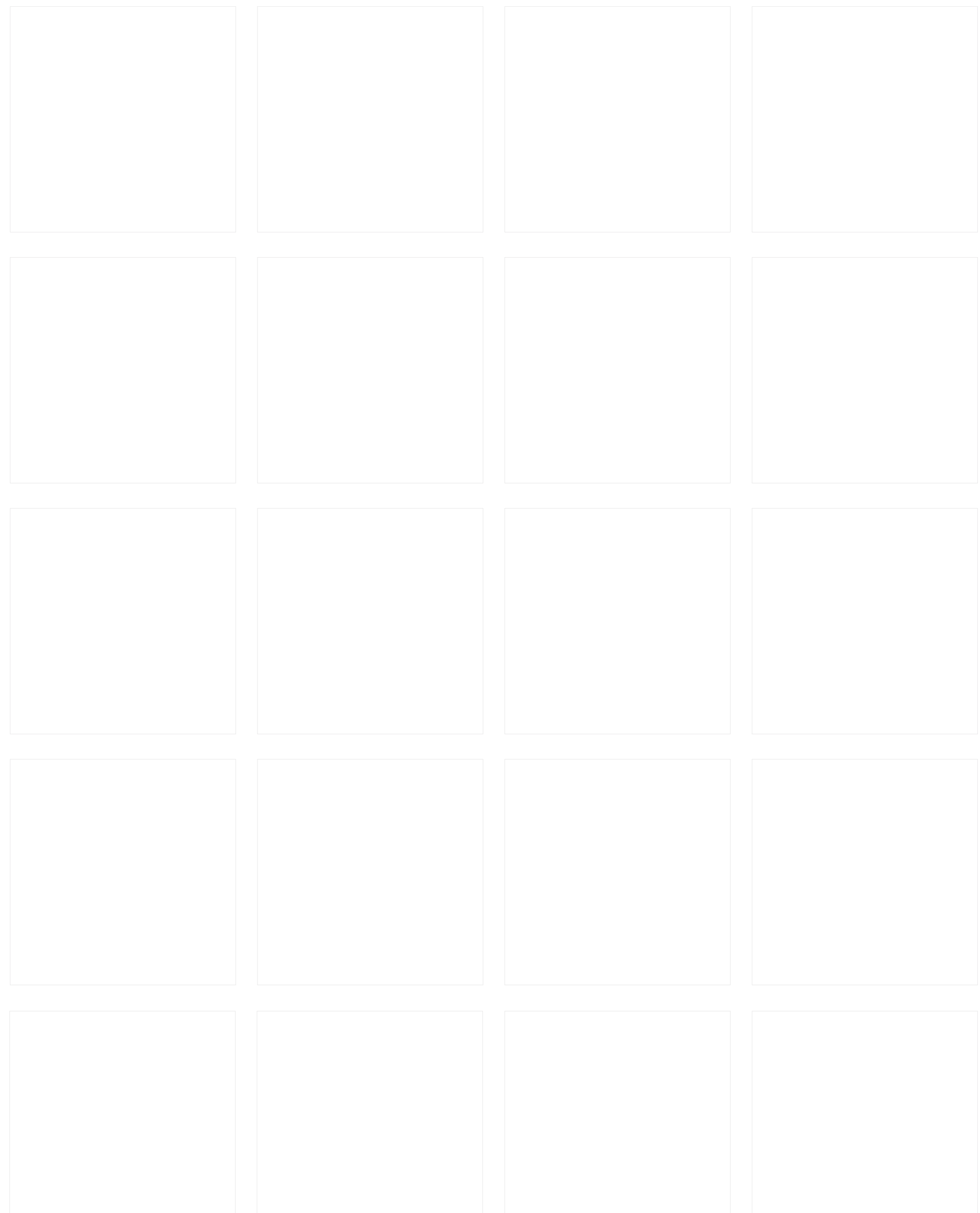
Arts District Form-Based Code 


\section{chapter 1}

\section{Introduction}

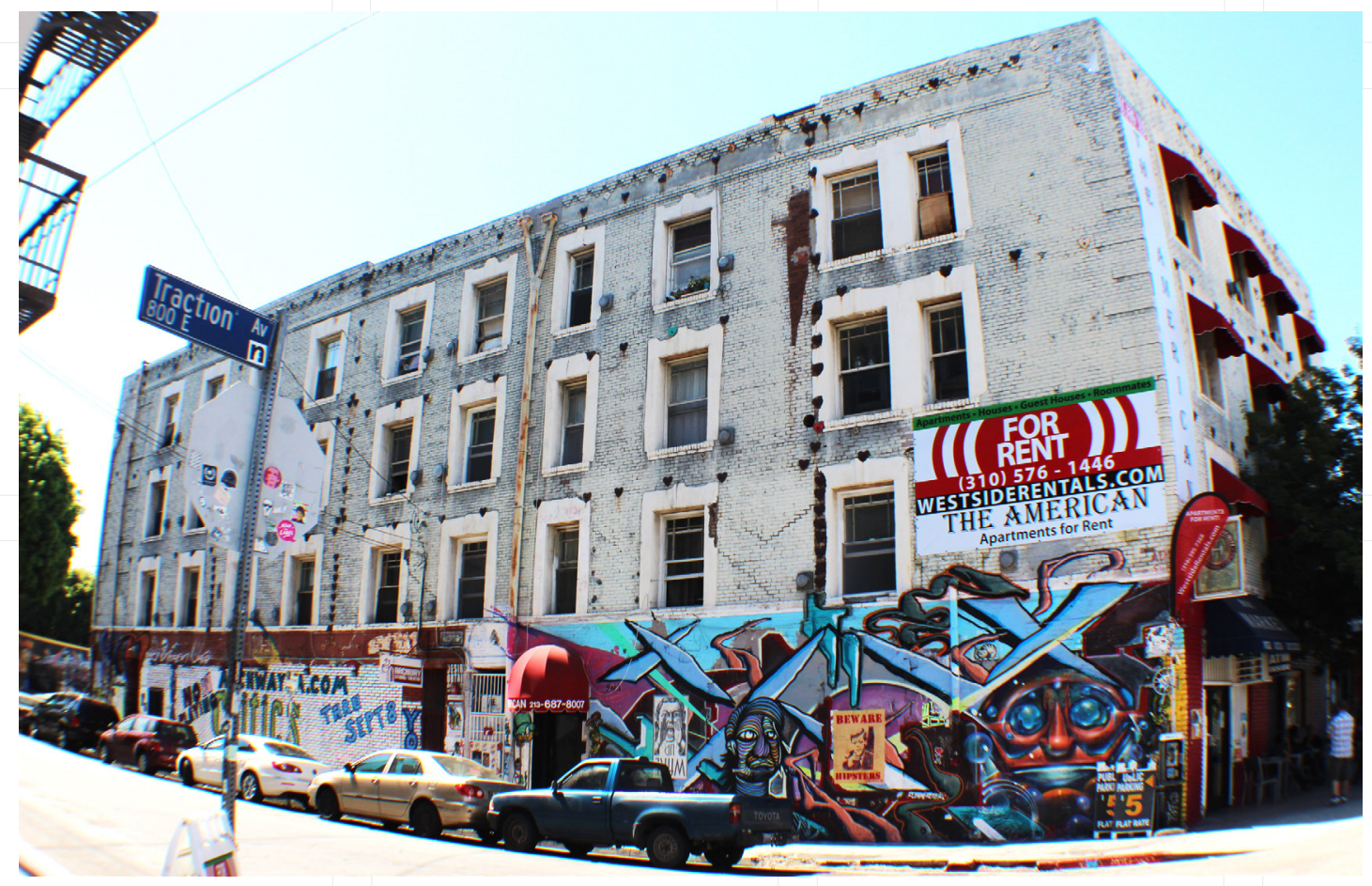

Left: The American Hotel built in 1905 is located along Traction Avenue in the core of the Arts District.

\section{What is a Form-Based Code?}

Form-based codes are defined as a type of land use regulation that focuses on the creation of predictable development patterns and high-quality public space. Form-based codes require all development to be cohesive so that it fosters a place envisioned by the community. A form-based code defines the physical form that identifies and emphasizes an urban hierarchy, rather than focusing on the separation of land uses found in conventional zoning codes. A form-based code is regulatory and not advisory. Furthermore, form-based codes help implement the vision of a community.

\section{Transect Based Approach}

The Arts District Regulating Plan will use the SmartCode, developed by Andres Duany and Elizabeth Plater-Zyberk, to establish an urban-to-rural transect-based approach to organize the form-based code. The urbanto-rural transect defines six Transect Zones (T-zones) that range from the most rural of intensities to the most urban. The classification of each zone within the Transect hierarchy is primarily determined by the building intensity, character, form, type of place, and secondly, by diversity of uses. This hierarchy is the framework for the Arts District form-based code and replaces the existing conventional zoning. Because the Arts District is in a primarily urban industrial neighborhood, the traditional Transect Zones may not apply to some areas. The Arts District Form-Based Code will use 
variations of the T5-Zone and SD- Zone. The following is a summary of Transect Zones found in the SmartCode:

- T-1 Natural Zone consists of lands approximating or reverting to a wilderness condition, including lands unsuitable for settlement due to topography, hydrology, or vegetation.

- T-2 Rural Zone consists of sparsely settled lands in open or cultivated state. These include woodland, agricultural land, grassland, and irrigable desert.

- T-3 Sub-Urban Zone consists of low density residential areas, adjacent to higher zones that have some mixed use. Home occupations and outbuildings are allowed. Planting is naturalistic and setbacks are relatively deep. Blocks may be large and the roads may be irregular to accommodate natural conditions.

- T-4 General Urban Zone consists of a mixed use but primarily residential urban fabric. It may have a wide range of building types: single, sideyard, and rowhouses. Setbacks and landscaping are variable. Streets with curbs and sidewalks define medium-sized blocks.

- T-5 Urban Center Zone consists of higher density mixed use building that accommodate retail, offices, rowhouses, and apartments. It has a tight network of streets, with wide sidewalks, steady street tree planting, and buildings set close to the sidewalks.

- T-6 Urban Core Zone consists of the highest density and height, with the greatest variety of uses, and civic buildings of regional importance. It may have larger blocks. Streets have steady street tree planting and buildings are set close to the wide sidewalks. Typically only large towns and cities have an Urban Core Zone.

- Civic Zone consists of Civic Buildings and/or Civic Spaces appropriate to their Transect Zones.

- Special Districts consist of areas with buildings distinguished by Function, Disposition, or Configuration and should not conform to one or more of the six normative Transect Zones.

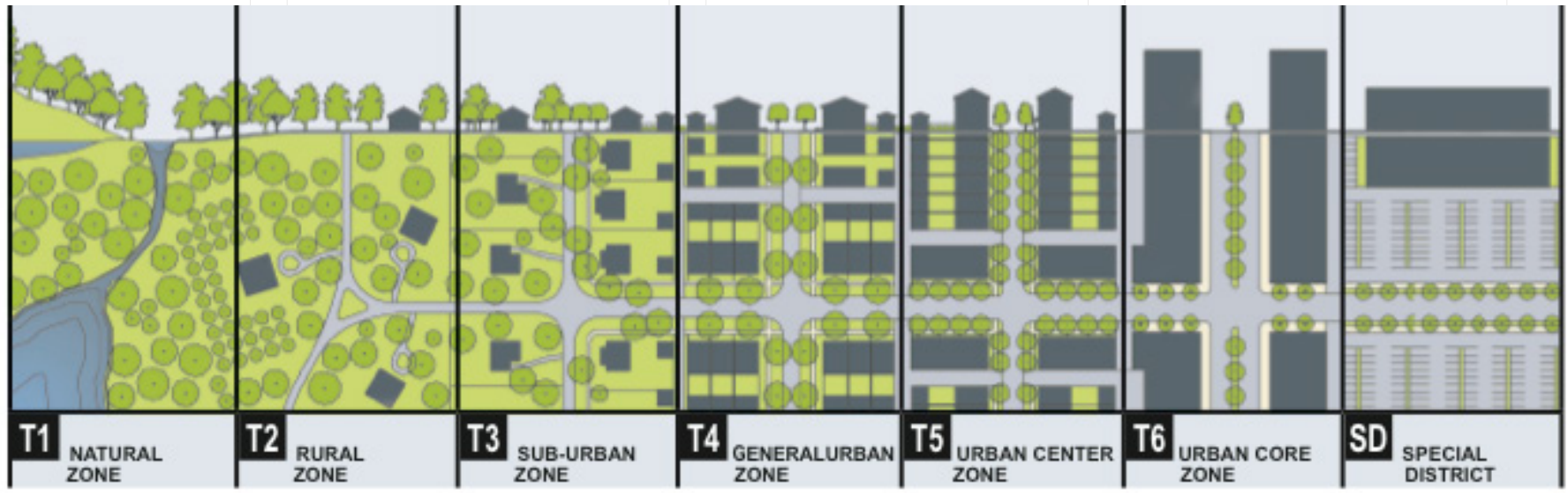

A Typical Rural-Urban Transect, with Transect Zones source: smartcode 


\section{Vision for the Arts District}

The Arts District Form-Based Code presents a regulatory framework for the Arts District's industrial live/work community that comprises of approximately seven blocks that are adjacent to the Fashion District and Little Tokyo. The Form-Based Code is an alternative to current zoning regulation for the existing pattern of urban design. The goal of the FormBased Code is to encourage a healthy and active community centered on a higher quality of life. The Form-Based Code also seeks to establish placespecific design to represent the unique industrial mixed-use and artistic character of the Arts District.

\section{Purpose and Intent}

The Regulating Plan of the Form-Based Code aims to implement a vision for the Arts District set forth by the 2000 Central City North Community Plan that encourages "the continued and expanded development of a thriving artists-in-residence community." In order to achieve the City's General Plan objectives, the Arts District Form-Based Code sets out to ensure "sustainable residential, commercial, and industrial development while maintaining the unique character of individual communities," and to create "healthier, more livable neighborhoods and economically viable business districts." In addition, the Regulating Plan facilitates "improved design of new and renovated structures and public spaces."

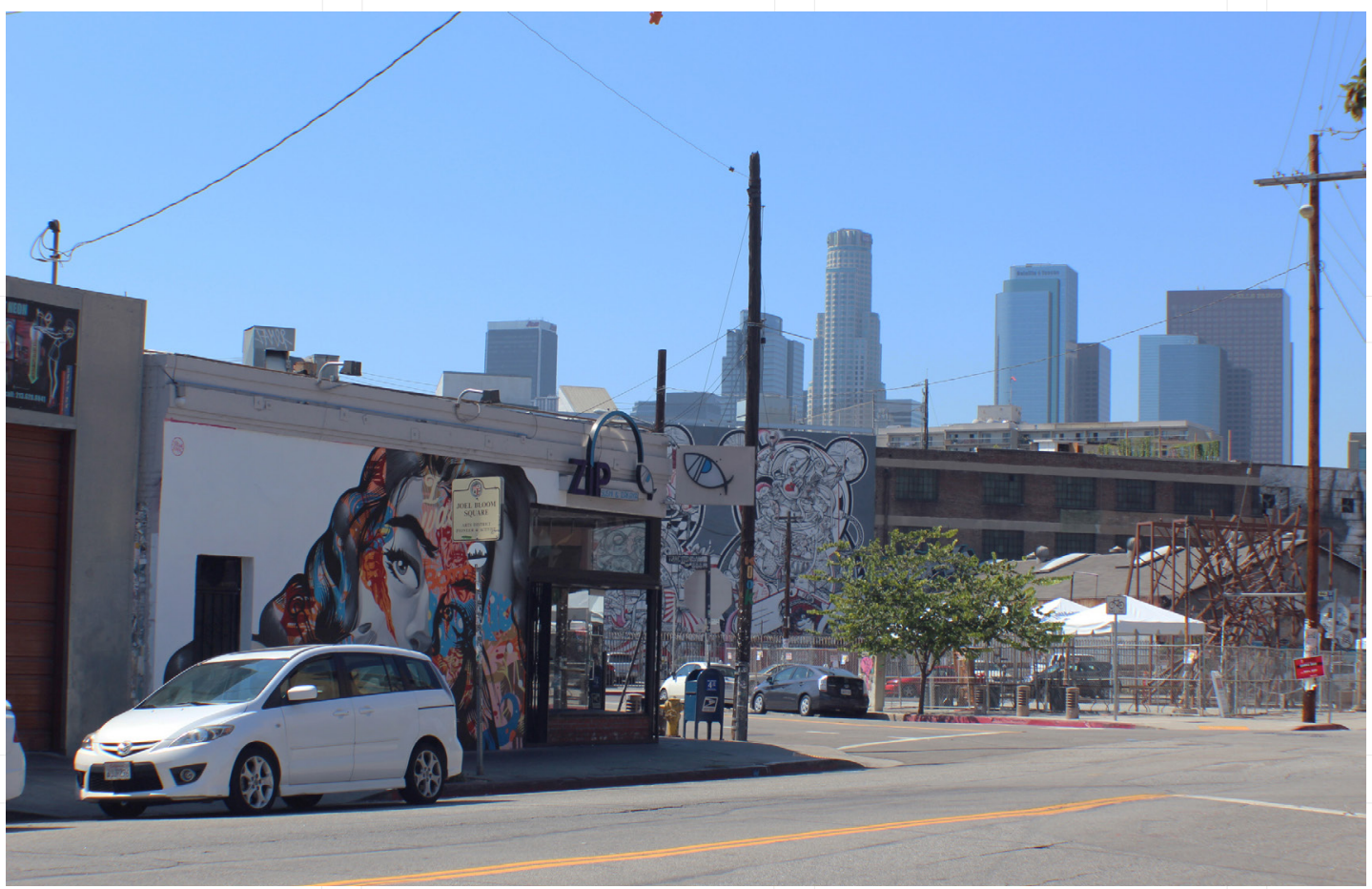

Left: The Arts District's proximity to Downtown Los Angeles. 
To further establish the Art District as a unique community, the Regulating Plan utilizes previous visioning processes in the Uncommon Ground workshop series (2006 and 2012) organized by The Los Angeles River Artists and Business Association and the Historic Cultural Neighborhood Council and hosted by SCl-Arc.

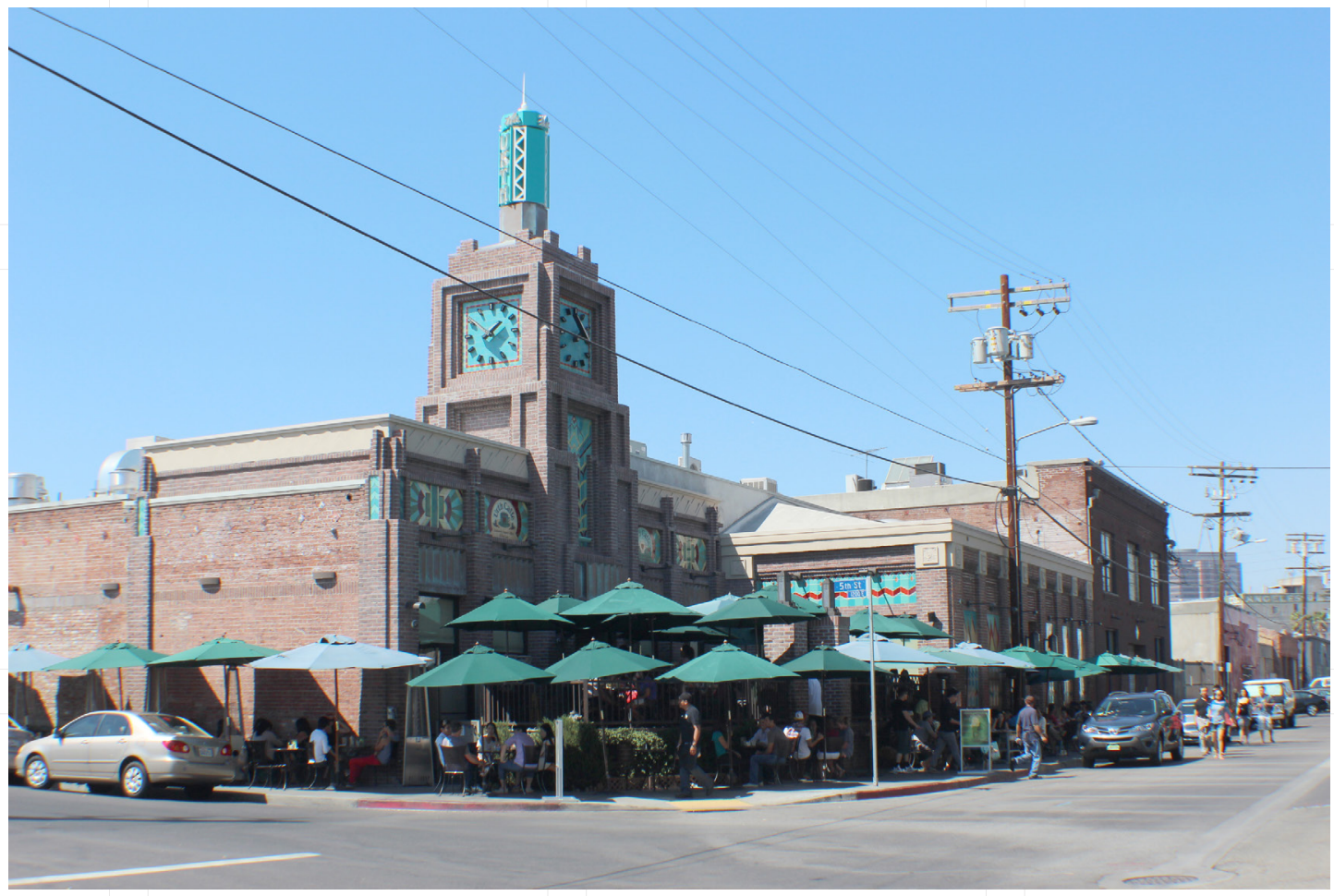

Above: The Arts District's industrial mixed use. 


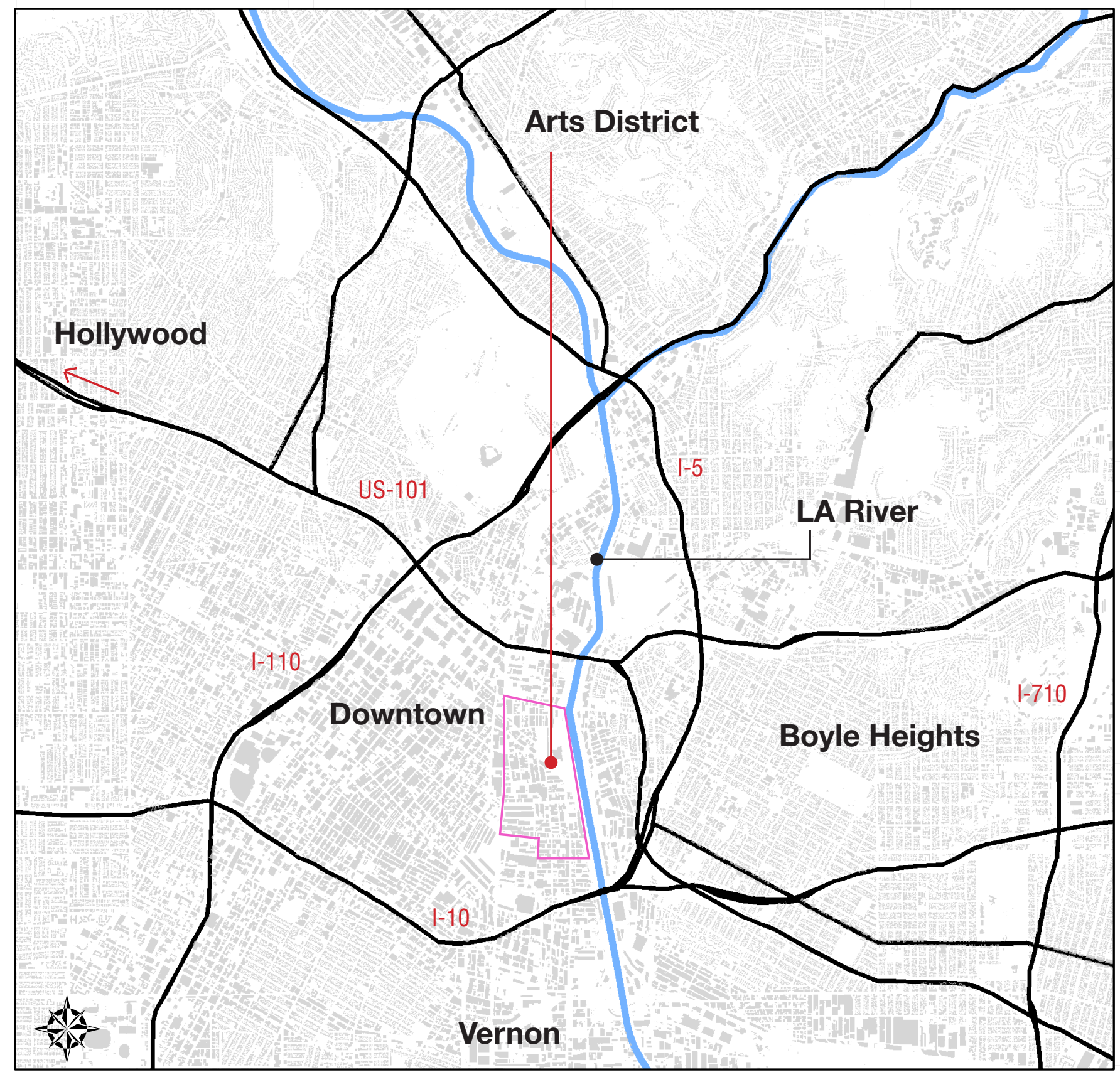

Figure 1. Regional Map of Los Angeles

\section{Regional Context}

The project area is located in the Arts District, a neighborhood on the eastern side of downtown Los Angeles, California. The Central City North Community Plan defines the District as bounded by "First Street, the Los Angeles River, Sixth Street, and Alameda Street." For the purpose of this plan the project area will also include the 2008 General Plan Amendment which expanded the boundary to include the area between Sixth and Violet Street to the south, Mill and Wilson Streets to the west and the Los Angeles River to the east. The project area comprises approximately 350 acres that span along the northern portion of the Alameda industrial corridor.
Above: Regional map of the Arts District in relation to adjacent communities. 


\section{Summary of Form-Based Code Process}

A literature review that details the history of zoning, the advent of formbased codes as an alternative to conventional zoning, and the history of land use in Los Angeles was conducted for the Arts District Form-Based Code. Numerous site visits, data collection, review of documents, and interviews were used to develop the Regulating Plan.

\section{Plans and Documents Reviewed}

The following plans and documents were reviewed, used to complete the site analysis, and used to form the Regulating Plan: City of Los Angeles General Plan, Central City North Community Plan, Los Angeles' Industrial Land: Sustaining a Dynamic City Economy, Central Industrial Redevelopment Project Area: Five Year Implementation Plan, Cleantech Corridor Los Angeles CA: A Vision for the Evolution of an Industrial Corridor, Alameda: ILUP Geographically Specific Directions, Uncommon Ground: Visions for the LA Arts District by Residents of the LA Arts District, Uncommon Ground III: Imaginings a Future for the Arts District, The Arts District: History and Architecture in Downtown LA by the Los Angeles Conservancy, SmartCode Version 9.2, San Francisco Planning Department Parklet Manual, City of Los Angeles Green Streets and Green Alleys Design Guidelines and Standards, Complete Streets Thoroughfare Assemblies SmartCode Module, and Bicycling SmartCode Module.

Right: Colloquium IX - The Evolution of Industrial and Mixed Use in Downtown LA: Conflict of Mutual Accommodation Arts District walking tour.

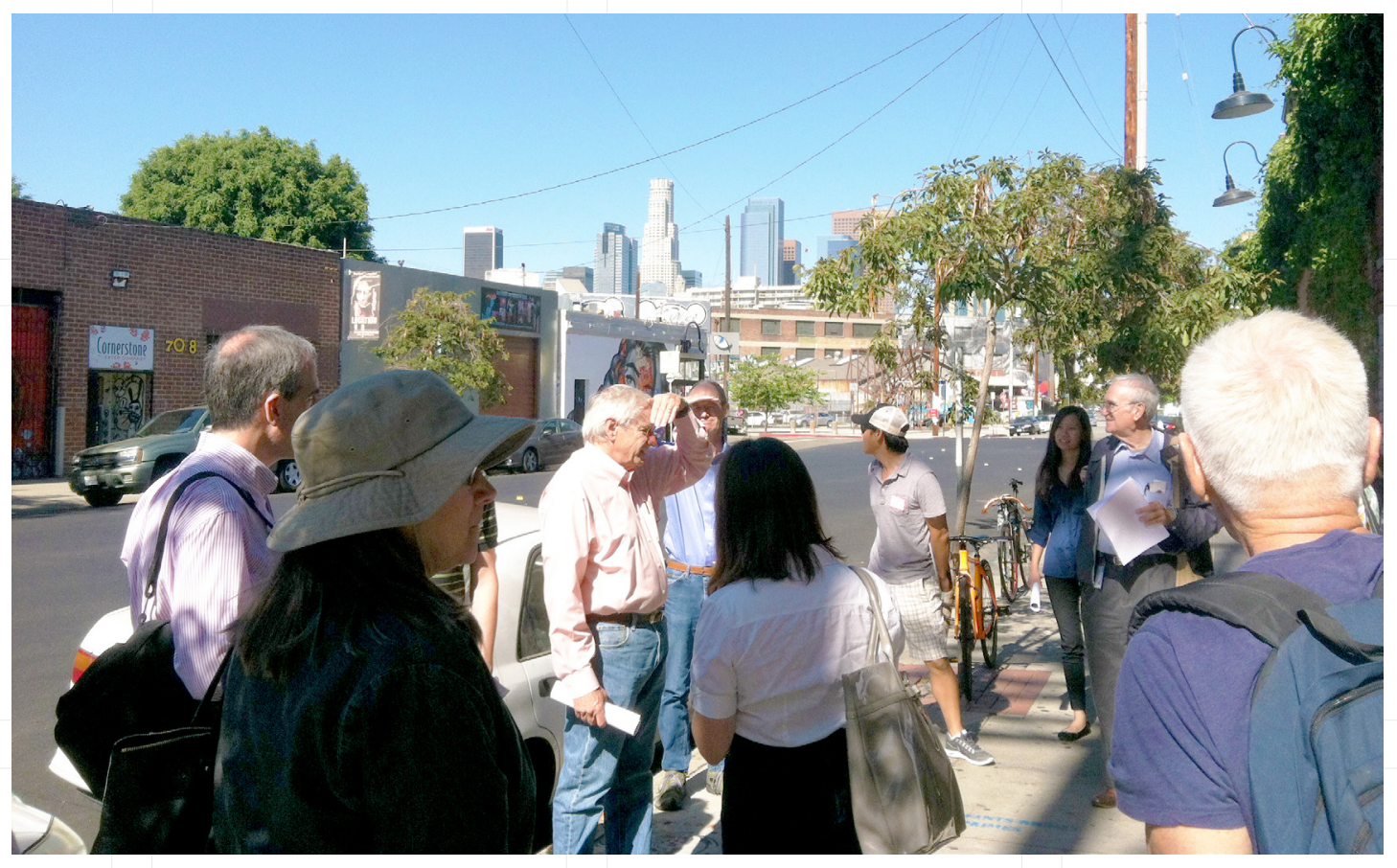




\section{Site Visits}

On October 5, 2013 the Southern California Institute of Architecture hosted the Los Angeles Region Planning History Group: Colloquium IX - The Evolution of Industrial Mixed Use in Downtown LA: Conflict of Mutual Accommodation. The purpose of this visit was to gain knowledge of the history of the Arts District and gather information on its rapidly-changing industrial neighborhood. A panel of speakers discussed Los Angeles' industrial legacy, present and future policy challenges, and potential planning policies for industrial land. The speakers included Alan Bell, Deputy Director of Planning with the City of Los Angeles, Yuval Bar-Zemer, Principal of Linear City Development, Donald Spivack the former Deputy Administrator and Deputy Chief of Operation for the Community Redevelopment Agency of Los Angeles, and Pouya Abdi, Principal of Parallel Acquisitions and Holdings.

On November 10, 2013 the Los Angeles Conservancy hosted a Walking Tour of the Arts District entitled Arts District: History and Architecture in Downtown L.A. The purpose of this visit was to gain an understanding of the area's historical architecture, building form, land use, culture, and pedestrian accessibility. Information gathered during these site visits was used as part of the site analysis and Regulating Plan.

Multiple visits between October 2013 and June 2014 were used to gather additional information.

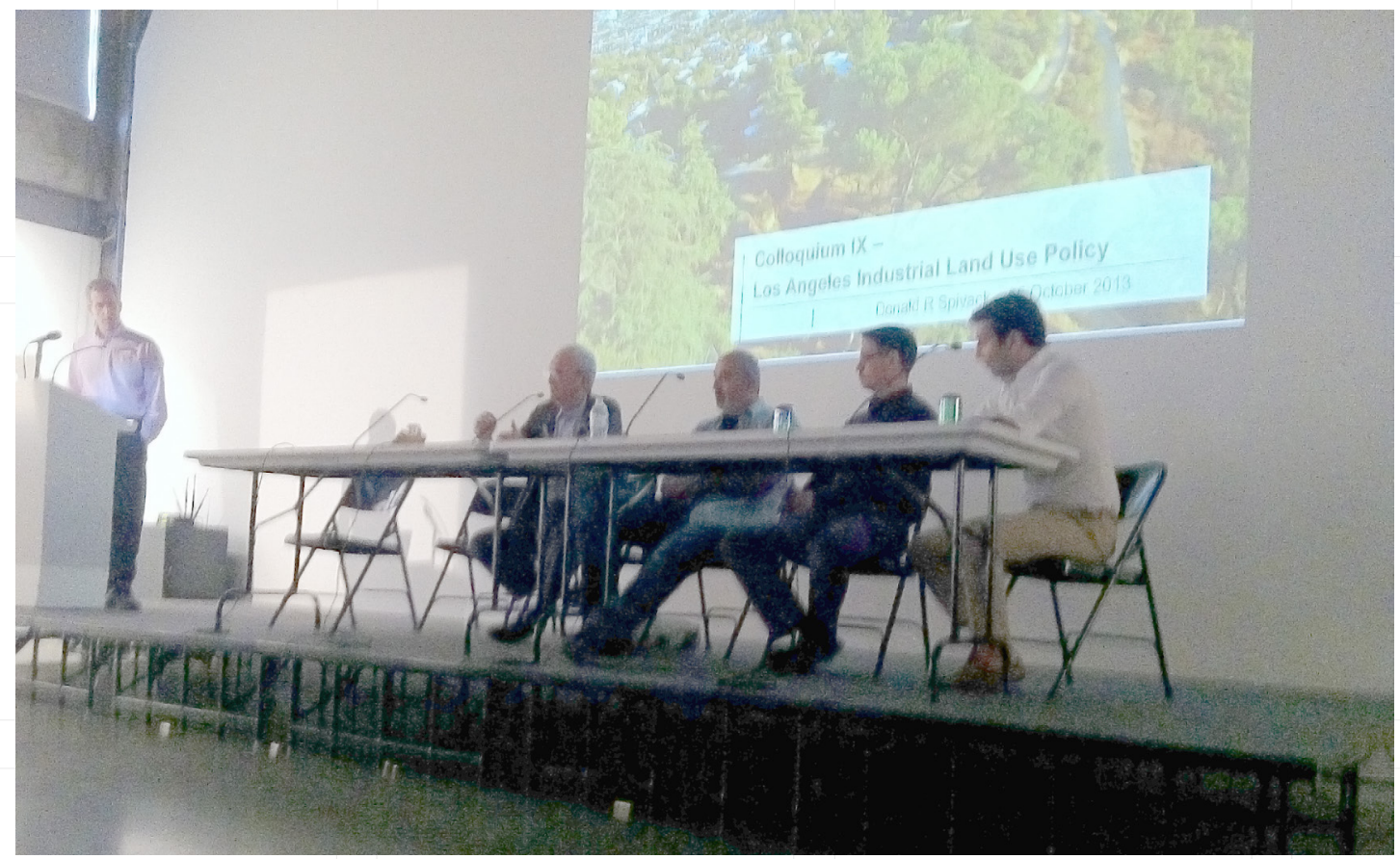

Left: Colloquium IX - The Evolution of Industrial and Mixed Use in Downtown LA: Conflict of Mutual Accommodation Speakers. Podium: Ken Bernstein. Panelists (left to right): Donald Spivack, Yuval BarZemer, Alan Bell, and Pouya Abdi. 


\section{Data Collection}

Data for the Regulating Plan was prepared and collected from various sources that include Mapshare: UCLA's Spatial Data Repository, Los Angeles County GIS Data Portal, METRO: Developer Metro's Official Blog of Transit Data and Technology, the United States 2010 Census, and the Los Angeles Department of Transportation Transit Services. Data was later synthesized into multiple maps, in order to analyze circulation and transit patterns, inventory recent development and adaptive reuse projects, and analyze the building fabric.

\section{Interviews}

A series of interviews were conducted to gather in-depth information on specific problems and concerns associated with the Arts District, development, form-based codes and industrial land use.

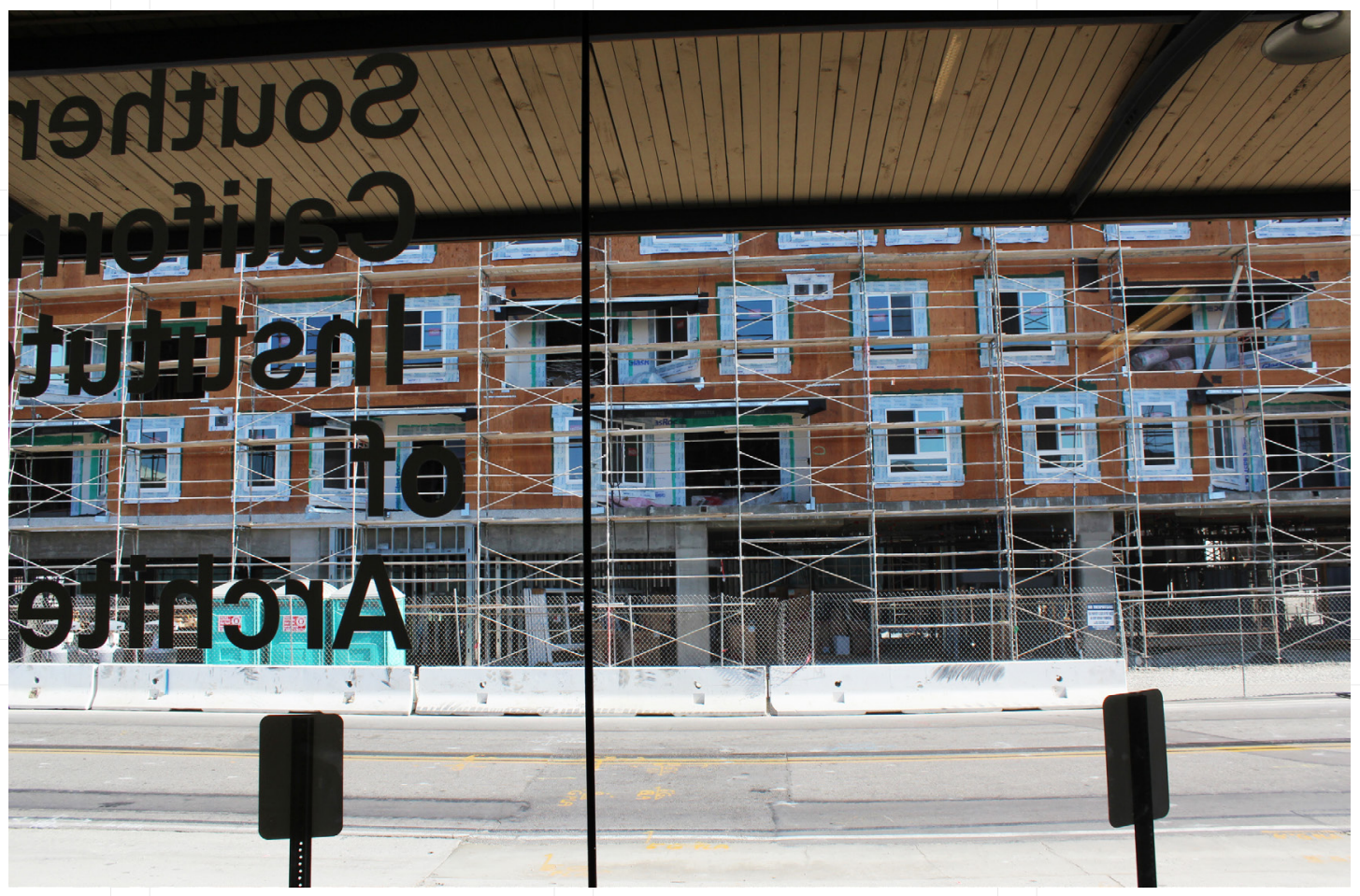

Above: New development is out of scale with existing buildings. One Santa Fe Transit Oriented Development looms over the existing SCI-Arc campus. 


\section{Key Strategies to Guide the Form-based Code:}

The data that was analyzed provided direction for the formation of the Regulating Plan. There were several common themes in the process are shown as follows:

Develop the Arts District into a cohesive community with a clear development pattern.

Ensure that the Arts District boundary is large enough to encompass future growth, but small enough to maintain its unique industrial and artistic character.

Maintain the District's unique character and sense of place that it gains from its architecturally distinctive buildings and industrial urban structure.

Incubate high tech business development through the utilization of relatively small parcel size and prime location near Union Station, local universities (Cal Tech, UCLA, USC etc.), services, and other institutions.

Catalyze a Cleantech corridor by capitalizing on historic infrastructure and the flexible nature of building stock.

Focus on the creation of more open and green space in residential nodes that includes parklets, pocket parks, community gardens, and tree planting; connect those resources with the Los Angeles River Revitalization Master Plan.

Improve circulation through enhanced pedestrian infrastructure, river access, the creation of thru-block pathways, dedicated bike lanes, public transit, and parking.

Enhance the arts culture of the District through more exhibition venues, public arts funding, historical walking tours, and a community art workspace.

Protect Industrial land uses and industrial jobs.

Encourage future development to be adaptive reuse, green building design, and focus on live/work units, affordable housing, and AIR housing.

Apply low-impact development standards that include green streets, storm water management, green roofs, and renewable energy sources. 
Arts District Form-Based Code 


\section{Site Analysis and Background Summary}

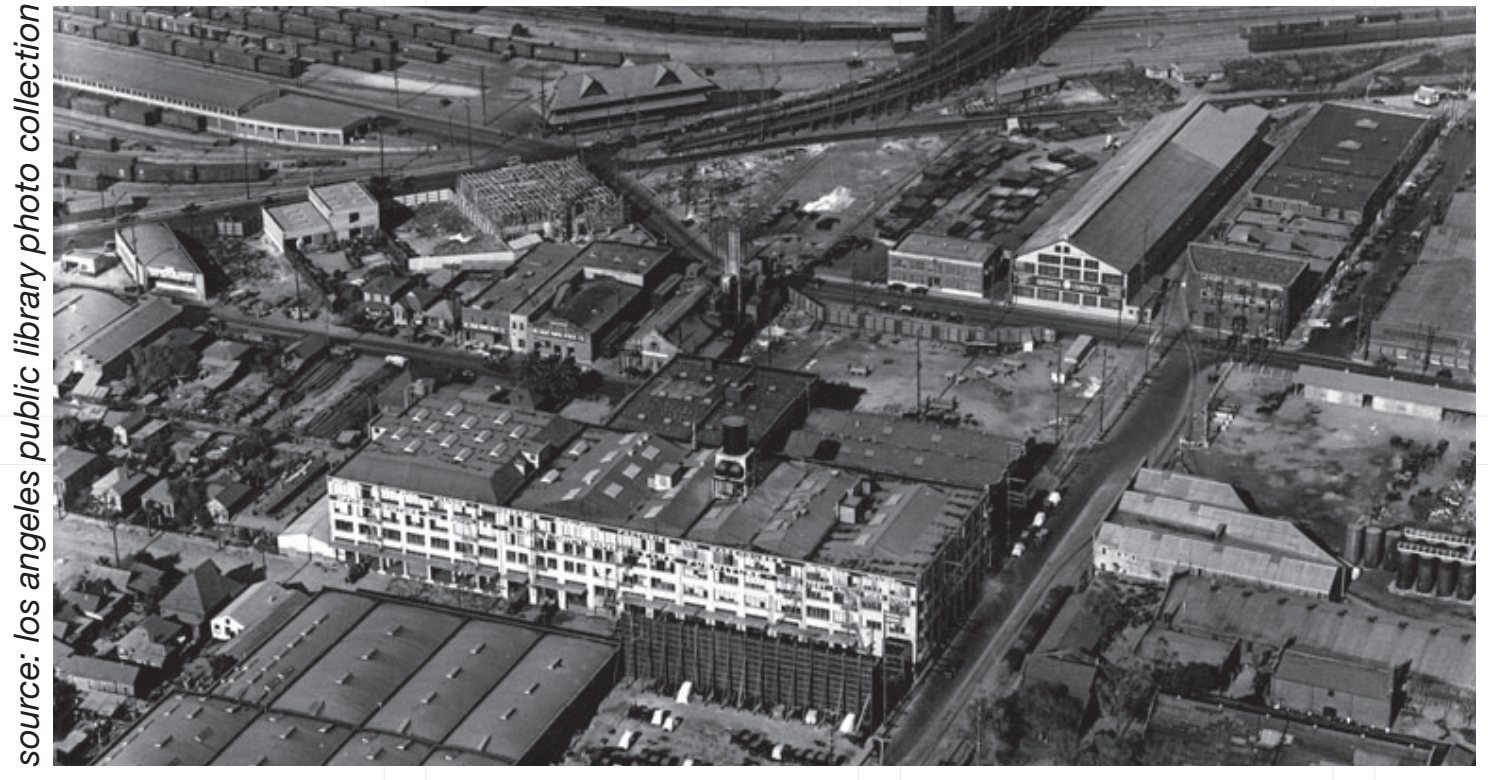

\section{Introduction}

This chapter details the approach that was used to conduct the site analysis for the Arts District in preparation for the development of the Form-Based Code. It summarizes the area's unique history and is followed by a thorough investigation of the Arts District's primary challenges and opportunities. The chapter also discusses the evaluation of building fabric, massing, zoning and land uses, existing development, and circulation.

The Arts District is regionally significant as a historical and cultural center within Los Angeles, and is categorized primarily by industrial land uses.

Since the late 1880s, the area has developed pockets of diverse land uses that contribute to the Arts District's unique identity. The Arts District has transformed into a vibrant mixed-use neighborhood due to its proximity to Downtown, continuing development of Los Angeles' transportation infrastructure, and the demand for housing in the area. However, industrial conversions and ground up construction continues to change the urban fabric of the Arts District and threaten adjacent industrial communities.

The Arts District supports a broad mix of land uses that include industrial, residential, commercial, office, and research institutions. The area also boasts one of the most extensive networks of street art within the city. These qualities exemplify the Arts District's established sense of place and suitability for a form-based code that will redefine the existing land use regulations to better reflect the collective vision for development within the Arts District.
Left: Ariel view of Arts District in 1924. Barker Bros factory and warehouses sit at the corner of Palmetto and S. Hewitt Street. Today the warehouses have been converted into 242 residences for the Barker Block development. The site across the street on the corner of Hewitt and Fifth is the future home of the LA Cleantech Incubator and $\mathrm{La}$ Kretz Innovation Campus. 


\section{Historical Context}

The area where the Arts District is now located was once characterized by acres of vineyards founded by the French immigrant Jean-Louis Vignes in the mid 1800s. At the end of the nineteenth century, the Southern Pacific Railroad, and later the Atchison, Topeka and Santa Fe Railroads arrived in Los Angeles. By 1905, the Union Pacific Railroad was built. It solidified the Arts District as the industrial, transportation, and manufacturing center for Los Angeles. Due to the needs of the three major transcontinental railroads, the building stock included of rail depots, transportation buildings, warehouses, and rail yards.

In the late 1880s the Arts District supported several residential neighborhoods. By 1922 the City of Los Angeles rezoned the area for

Bottom Left:

French immigrant Jean-Louis Vignes' orchard and vineyards taken in 1885. Vignes Street which runs through the northern portion of the Arts District was named after him. Bottom Right: Santa Fe La Grande railroad station built in 1893. The station was damaged by the 1933 Long Beach earthquake and was later replaced by Union Station in 1939. industrial uses that sanctioned it as an industrial and manufacturing center. After World War II the Arts District struggled to compete with neighboring cities that could better accommodate the needs of modern industries. The Arts District's small parcel sizes and narrow streets were not ideal for the emerging trucking industry and larger manufacturing plants. The infrastructure began to deteriorate. Many buildings were left vacant and dilapidated as companies moved to neighboring cities such as Vernon and the City of Commerce.

In the 1970s, artists who were priced out of the Art scene in Hollywood and Venice began to illegally move into the area. The vacant warehouses were ideal for live/work studios and were sold and leased to artists at below market-rates. In 1981, the City acknowledged this migration into the Arts District and legalized the residential use of former industrial buildings through the Artist-in-Residence (AIR) program. In the early 1990s, the Arts District became the official name of the area as a means of marketing it after the economic recession.
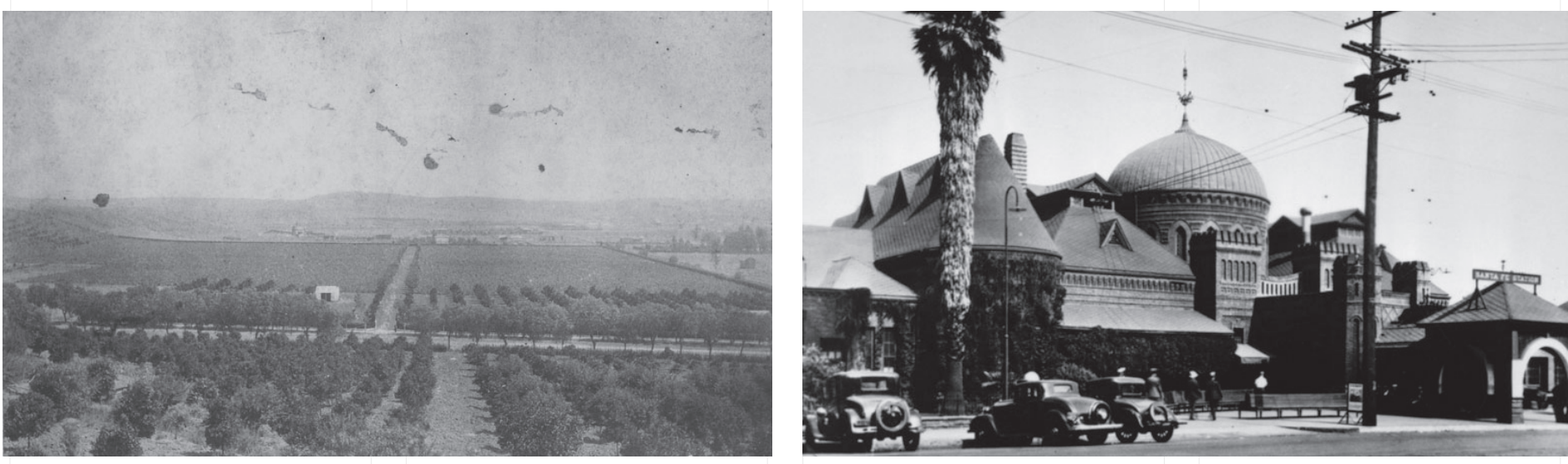

source: los angeles public library photo collection 
By the late 1990s, the Arts District had become a culturally rich and unique place to live. It experienced a wave of development with the landmark 1999 passage of the Adaptive Reuse Ordinance (ARO) that allowed the conversion of pre-1974 commercial and industrial buildings into residential buildings for non-artists. Today, the Arts District attracts artists, developers, residents, and a wide variety of professional firms while it continues to have a solid industrial base. Recently, there has been commercial and residential development, built from the ground up, that lacks consistency with the character and scale of the existing building stock.

The increase in non-industrial uses in the Arts District results in lost opportunity for industrial land users. Residential project approvals encourage landowners and residential developers to purchase land with the expectation that government officials will approve of zone changes so that non-industrial uses may be allowed on their property in the future. As a result, the loss of industrial land increases land values and lease costs which further displace industrial users. Conflicts between industrial and residential uses can also arise due to nuisances such as industrial truck traffic, dust, operational noise, potential odors, and business hours for industrial uses. The FormBased Code's intent to promote clear, consistent, and predictable patterns of development will reduce conflicts while maintaining the unique industrial character of the Arts District neighborhood.

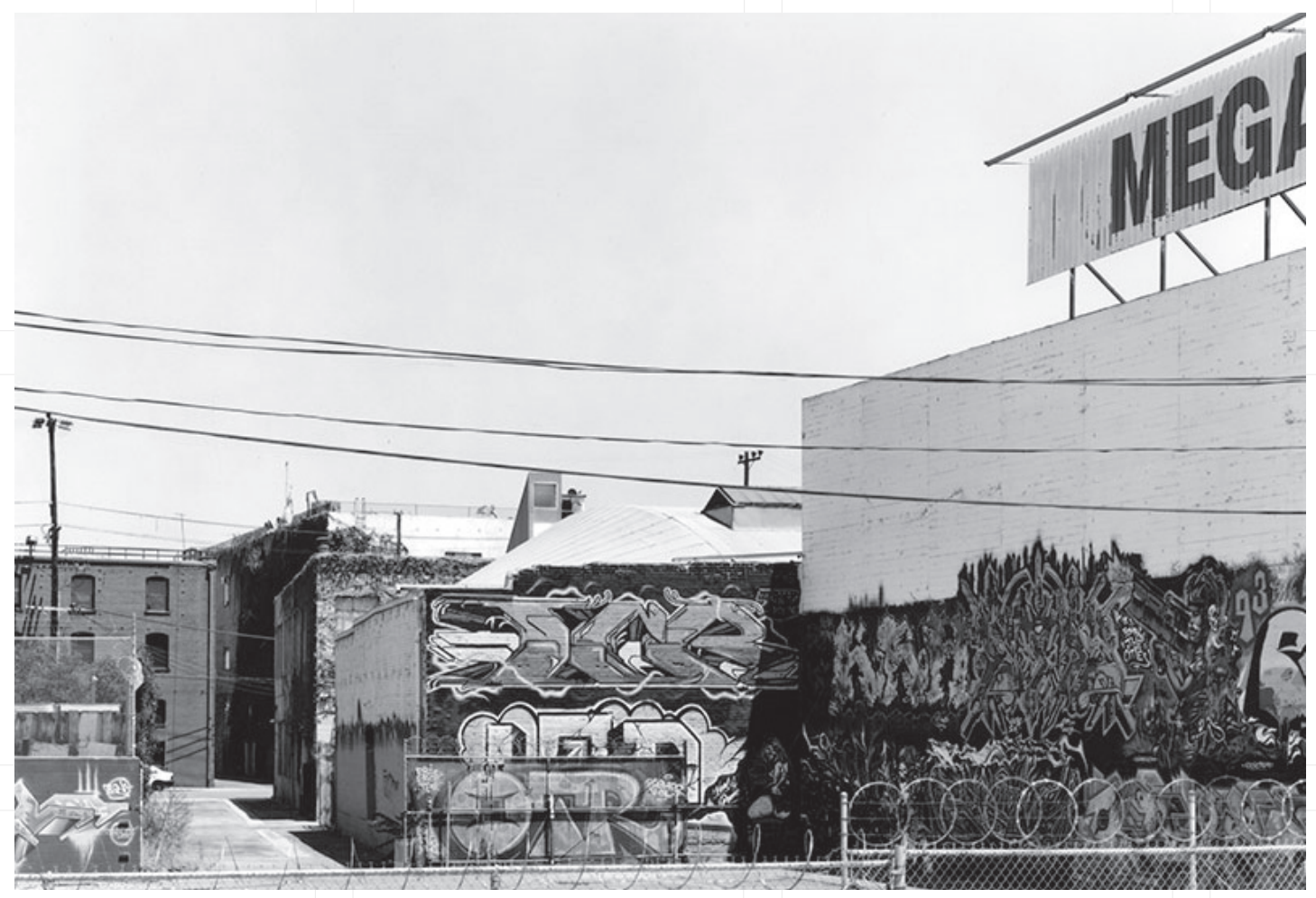

source: los angeles public library photo collection
Left: Original location of the Westinghouse Electric Supply Company Art Deco warehouse built in 1929. The industrial warehouse will be demolished in preparation for the East Village ground up development. 


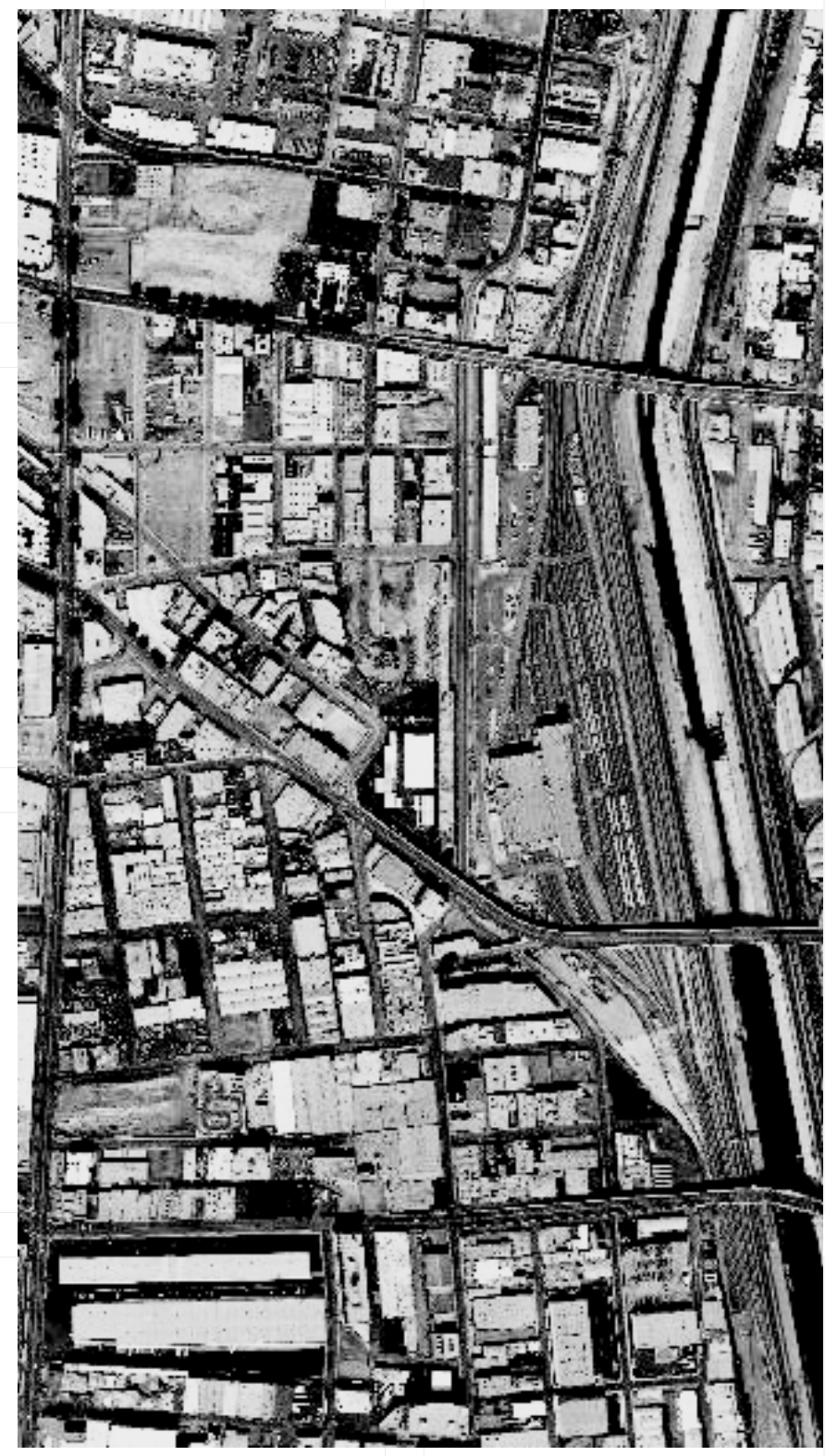

2001

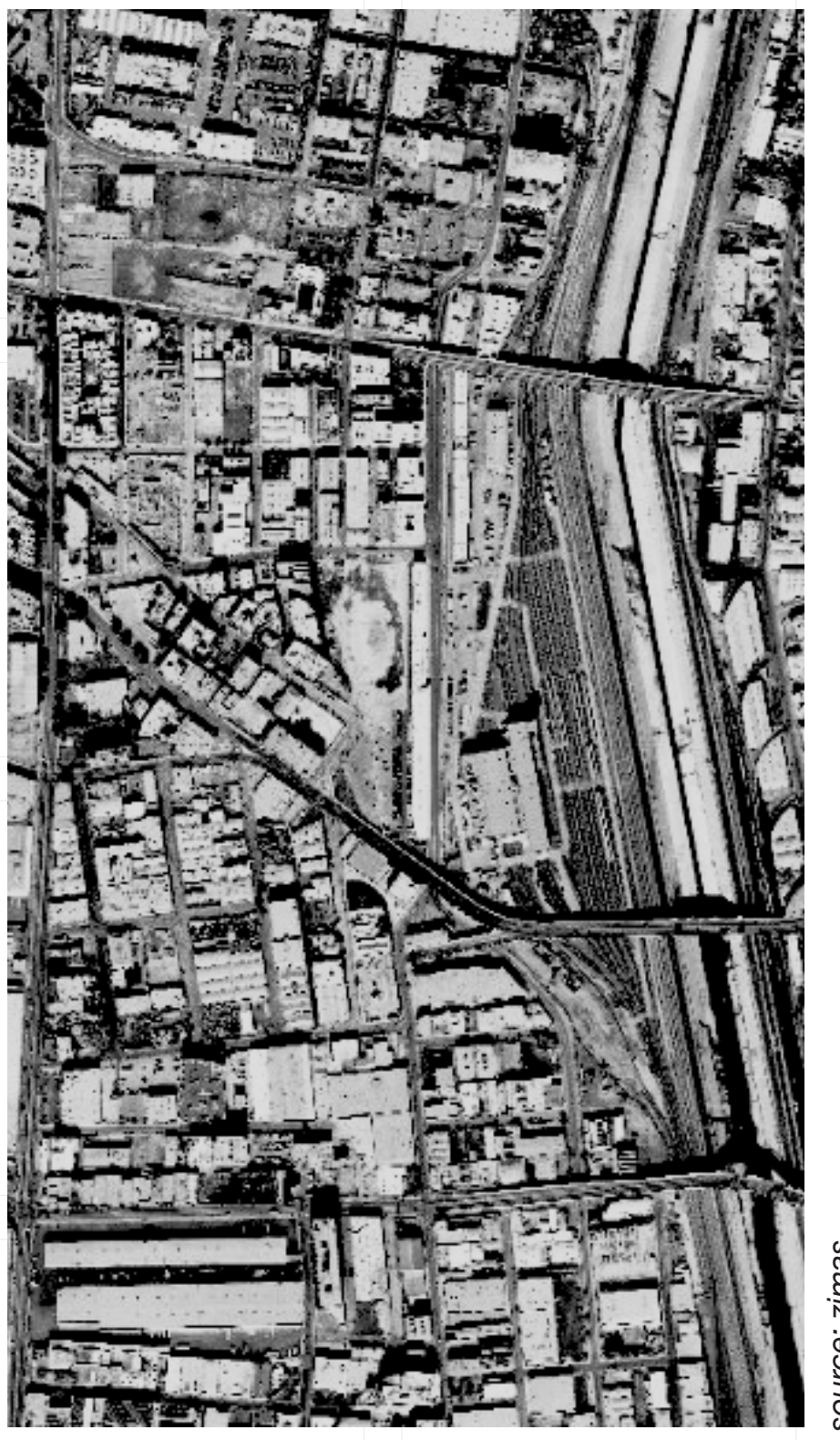

2006

Above: Development snapshot of the Arts District from 2001 to 2006. Three sites in the upper left of the Arts District are cleared in preparation for ground up residential development. 


\section{Arts District Aerial Snapshot 2008 - 2011}

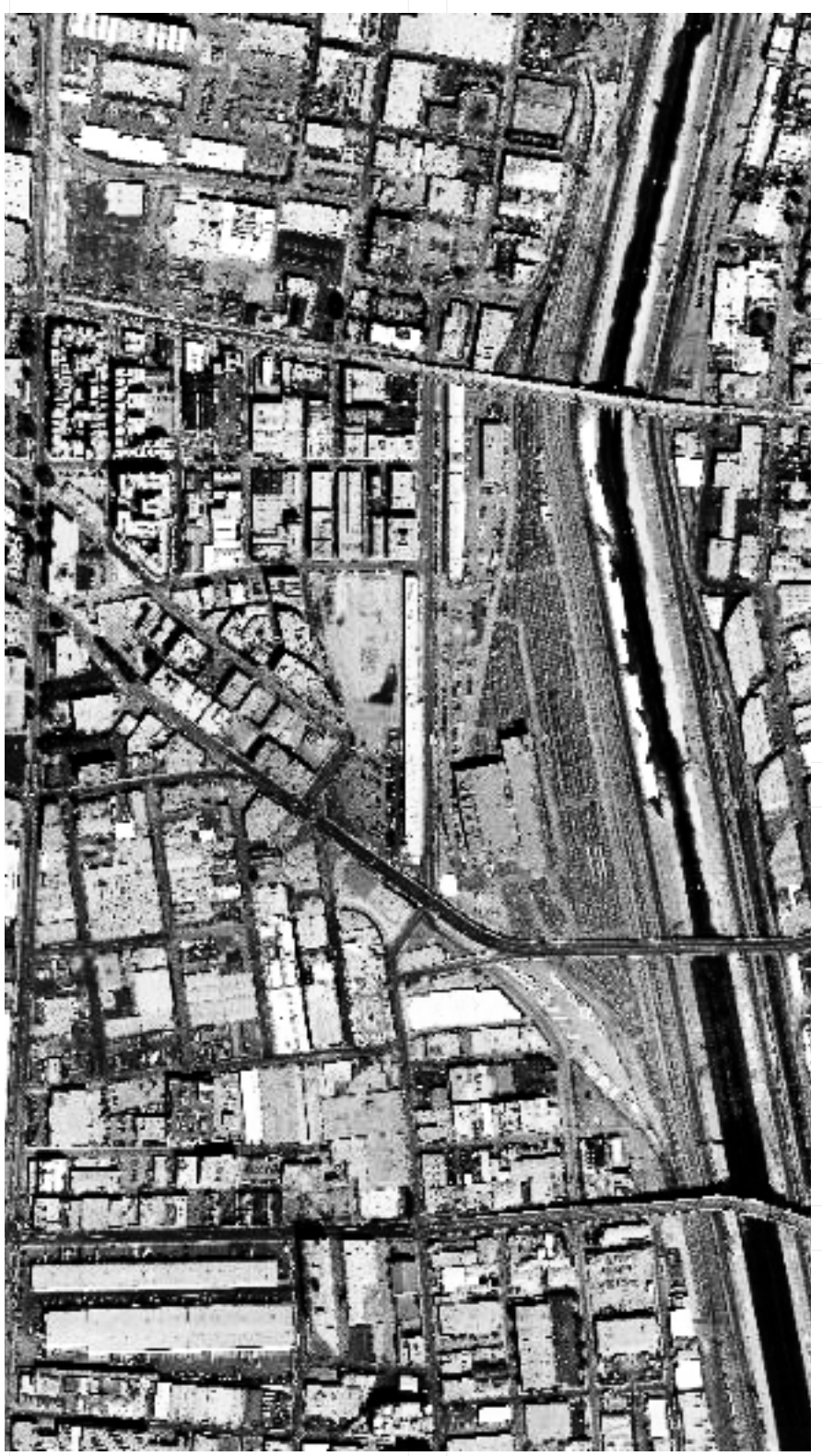

2008

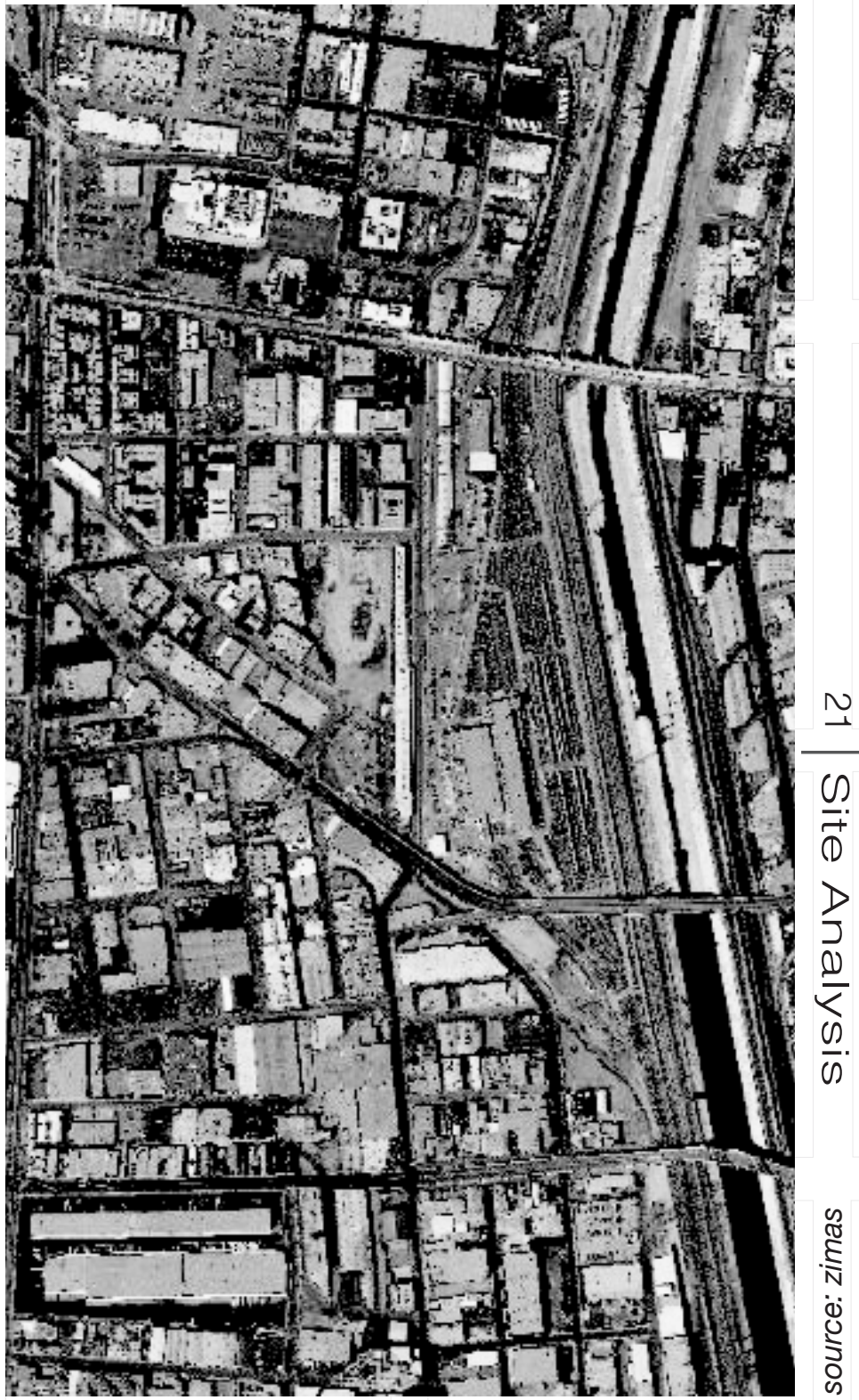

2011

Above: Development snapshot of the Arts District from 2008 to 2011. By 2008 construction of the three sites in the previous two snapshots, Alexan Savoy, Mura Condominiums, and Artisan on Second have been completed adding 611 residential units to the Arts District. The area continues to experience a wave of residential and commercial development through ground up and reuse projects. 

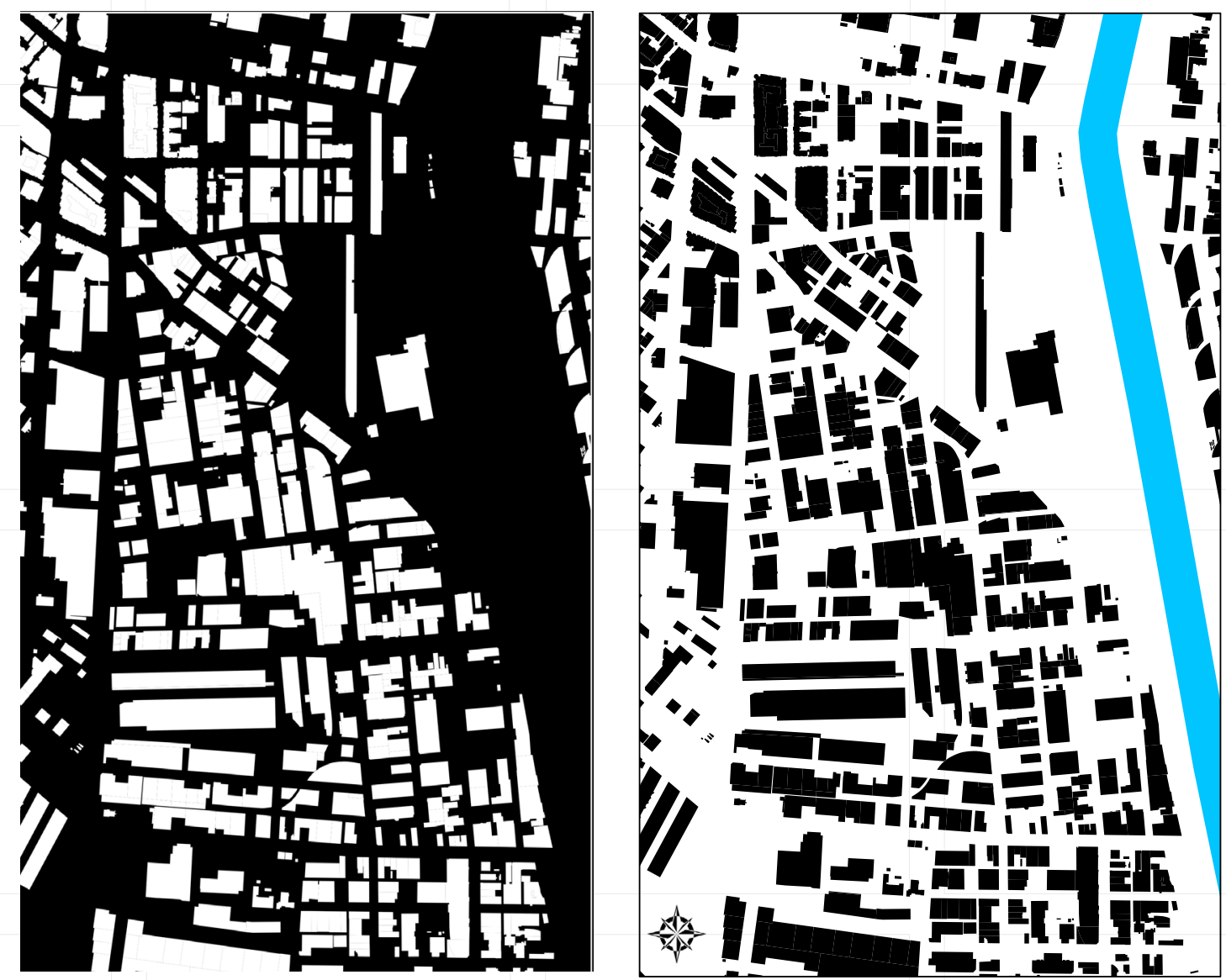

Figure 2. Figure Ground and Building Fabric

\section{Figure Ground and Building Fabric}

The buildings in the Arts District primarily include of industrial warehouses that are built to the property line. These buildings take up a significant portion of each block that often extends from one side to the other. The area comprises of large blocks that are interspersed with narrow streets. The Arts District is built out at approximately $75 \%$. The unbuilt space is concentrated in the northeastern area of the Arts District and is composed of the rail yard and large surface parking lots.

\section{Zoning, Land Use and Open Space}

The Arts District is mainly zoned for heavy industrial although most land uses are light industrial and fabrication. The area north of Third Street is the only portion that is not zoned heavy industrial and is instead zoned as commercial and commercial manufacturing. Because the area has been primarily industrial throughout its history land was never allocated for neighborhood open or green space. The area boasts a single park, for dogs, Saslow Dog Park. 


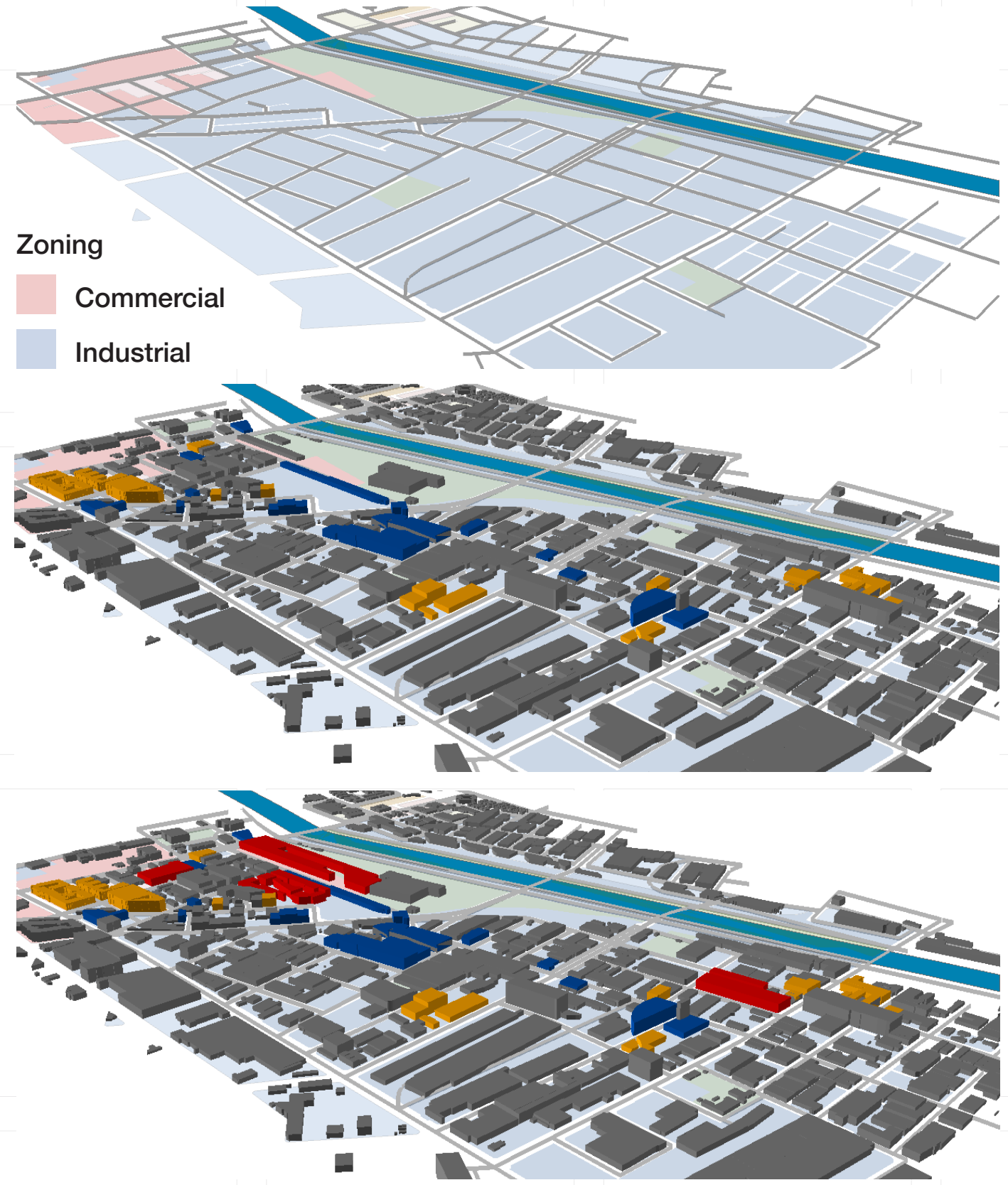

Top: The Arts

District's existing zoning.

Middle: Massing overlay on top of zoning. Historical buildings (b/ue) and existing development (yellow).

Bottom: Proposed development will add an additional 1410 residential units with the One Santa Fe (438), 950 Third (472), Amp Lofts (180), and East Village (320).

Figure 3. Building Massing and Zoning

A collection of residential pockets has also developed throughout the Arts District since artists first began to migrate in the 1980s. New residential development in the Arts District is concentrated in-between First and Fourth Street. East Village, One Santa Fe, and 950 Third will bring approximately 1200 new residential units to the area. Residential conversions are concentrated around Mateo Street and include the Barker Block, Toy Factory, Biscuit Company, Mateo Street, Molino Street, and Industrial Lofts. Buildings built prior to 1950 or Buildings, that have been designated Los Angeles Historic-Cultural Monuments, are classified as historically significant and can be seen in conjunction with a development profile in the Arts District Illustrative Map. 
Table 1. Development Profile

\begin{tabular}{|c|c|c|c|c|}
\hline \multicolumn{5}{|l|}{ Development Profile } \\
\hline $\begin{array}{l}\text { Residential } \\
\text { (New Construction) }\end{array}$ & & Address & Units & Completed \\
\hline Alexan Savoy & (1) & 100 S Alameda & 303 & 2006 \\
\hline Artisan on 2nd & 2 & $601 \mathrm{E} 2 \mathrm{nd}$ St & 118 & 2008 \\
\hline Mura Condominiums & 3 & 629 Traction Ave & 190 & 2007 \\
\hline \multicolumn{5}{|c|}{ Adaptive Reuse/ Residential Conversion } \\
\hline Beacon Lofts & 4 & $825 \mathrm{E}$ 4th St & 53 Live/Work & 2012 \\
\hline 811 Traction Lofts & 5 & 811 Traction Ave & $10 \mathrm{AlR}^{\star}$ & 1990 \\
\hline Newberry Lofts & 6 & $900 \mathrm{E} 1$ st St & 45 & NA \\
\hline Gallery Lofts & 7 & 130 S Hewitt St & 33 & 2009 \\
\hline Toy Factory Lofts & 8 & 1855 Industrial St & 119 Live/Work & 2004 \\
\hline $929 \mathrm{E} 2 \mathrm{nd}$ St & 9 & $929 \mathrm{E}$ 2nd St & 14 AIR & 1990 \\
\hline $810 \mathrm{E}$ 3rd St & (10) & $810 \mathrm{E} 3 \mathrm{rd} \mathrm{St}$ & $10 \mathrm{AIR}$ & 1990 \\
\hline American Hotel & (1) & 303 S Hewitt St & 39 AIR & 1990 \\
\hline Biscuit Company Lofts & 12 & 1850 Industrial Street & 109 Live/Work & 2007 \\
\hline Federal Industrial Lofts & $(13$ & 2117,2135 E 7th PI & 67 & 2002 \\
\hline Barker Block & $14:$ & 510-530 Hewitt St & 297 & 2007 \\
\hline Industrial Lofts & 15 & 1800 Industrial St & 36 & NA \\
\hline Sixth Street Lofts & 16 & 1291 6th St & $63 \mathrm{AIR}$ & 2008 \\
\hline 726 Santa Fe Ave & 17 & 726 S Santa Fe Ave & 22 & 2006 \\
\hline Brick Lofts & 18 & 652 Mateo St & 21 Live/Work & NA \\
\hline Factory Place Lofts & 19 & 1291-1333 Factory Place & 180 & 2009 \\
\hline Molino Street Lofts & 20 ! & 530 Molino St & 91 Live/Work & 2005 \\
\hline Binford Lofts & (2) & 857 Traction Ave & 39 & 1990 \\
\hline $2101 \mathrm{E} 7$ th St & 22 & $2101 \mathrm{E} 7$ th St & 39 & NA \\
\hline SRO Hotel & $\sqrt{3}$ & & NA & NA \\
\hline \multicolumn{5}{|l|}{ Proposed Development } \\
\hline One Santa Fe (New) & 24 & S Santa Fe Ave and 1st St & 438 & TBD \\
\hline East Village (New) & 5 & 2nd \& S Garey St & 320 & TBD \\
\hline AMP Lofts (New) & 26 & 695 S Santa Fe Ave & 180 & TBD \\
\hline 950 Third & 28 : & 950 Third Street & 472 & TBD \\
\hline Atlas LA 4th St. LLC (Reuse) & 28: & $963 \mathrm{E}$ 4th St & Office TBD & TBD \\
\hline
\end{tabular}




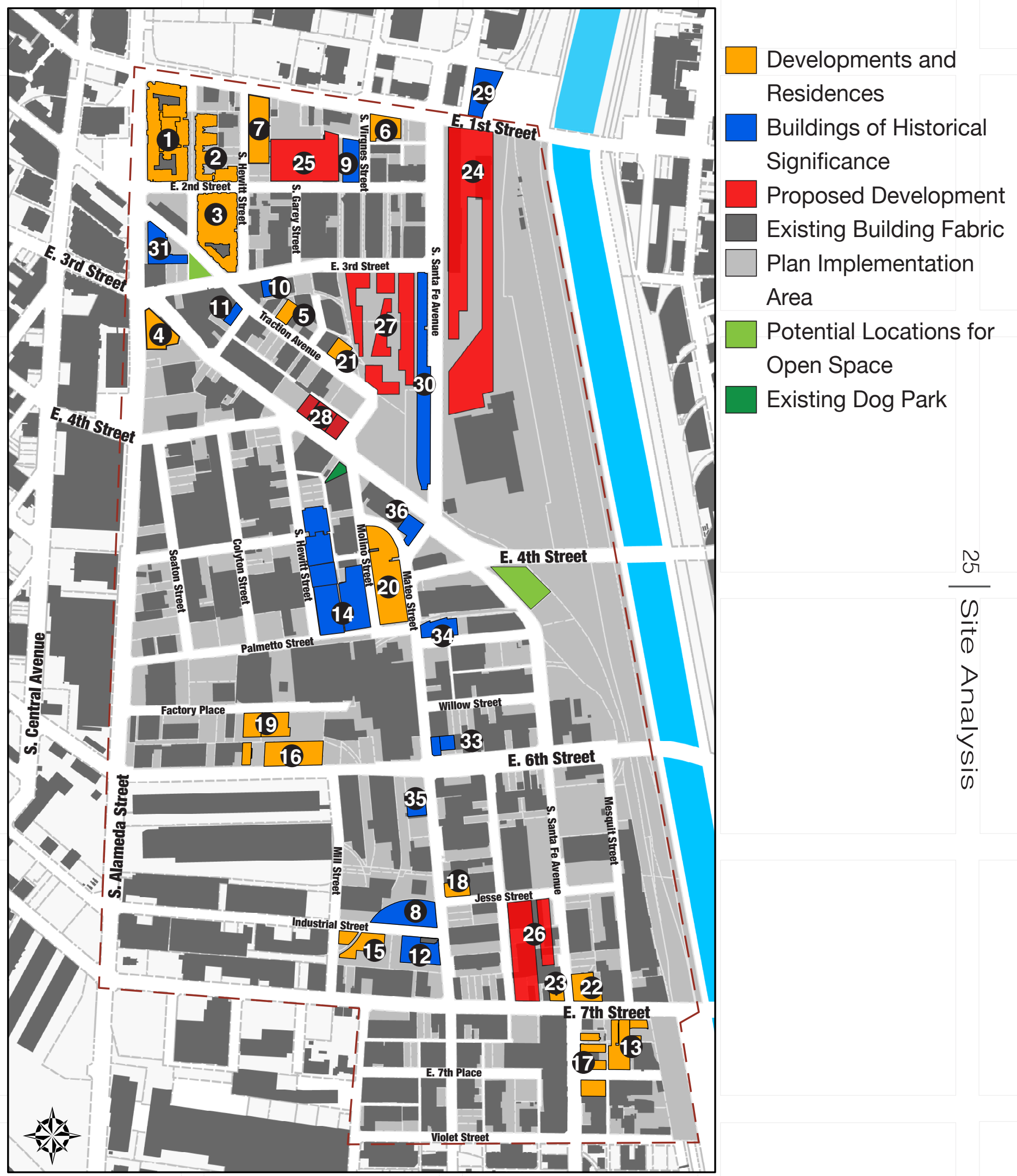

Figure 4. Illustrative Map 
Table 2. Historical Building Profile

\begin{tabular}{|c|c|c|}
\hline \multicolumn{3}{|l|}{ Historically Significant Buildings* } \\
\hline Buildings Built Before 1950 & & Built \\
\hline Pickle Works & 1001 E First St & 1888 \\
\hline Toy Factory Lofts & 1855 Industrial St & 1924 \\
\hline Challenge Dairy Building & $929 \mathrm{E}$ 2nd St & 1926 \\
\hline Southern CA Supply Co & 810 E 3rd St & 1910 \\
\hline SCl-Arc (Santa Fe Freight House) & $960 \mathrm{E}$ 3rd St & 1906 \\
\hline Angel City Brewery & 216 S Alameda St & 1913 \\
\hline American Hotel & 303 S Hewitt St & 1905 \\
\hline Biscuit Company Lofts & 1850 Industrial St & 1925 \\
\hline Stover Seed Company Building & 592 Mateo St & 1946 \\
\hline Nate Starkman \& Son Building & 544 Mateo St & 1908 \\
\hline Southwestern Bag Co Building & $1380 \mathrm{E} 6$ th St & 1924 \\
\hline Maxwell House Building & 405 Mateo St & 1924 \\
\hline Former Coca-Cola Production Building 28 & $963 \mathrm{E}$ 4th St & 1915 \\
\hline
\end{tabular}

${ }^{*}$ Refer to Illustrative Map.

\section{Industrial Land Use + Jobs Profile}

There is a growing trend in the loss of heavy manufacturing within Los Angeles. An industrial land survey of comparable cities, prepared by the Seattle Department of City Planning in 2007, stated that heavy manufacturing is being replaced by light industrial. The Urban Land Institute further substantiated this finding in $\mathbf{2 0 1 0}$ when they released The Cleantech

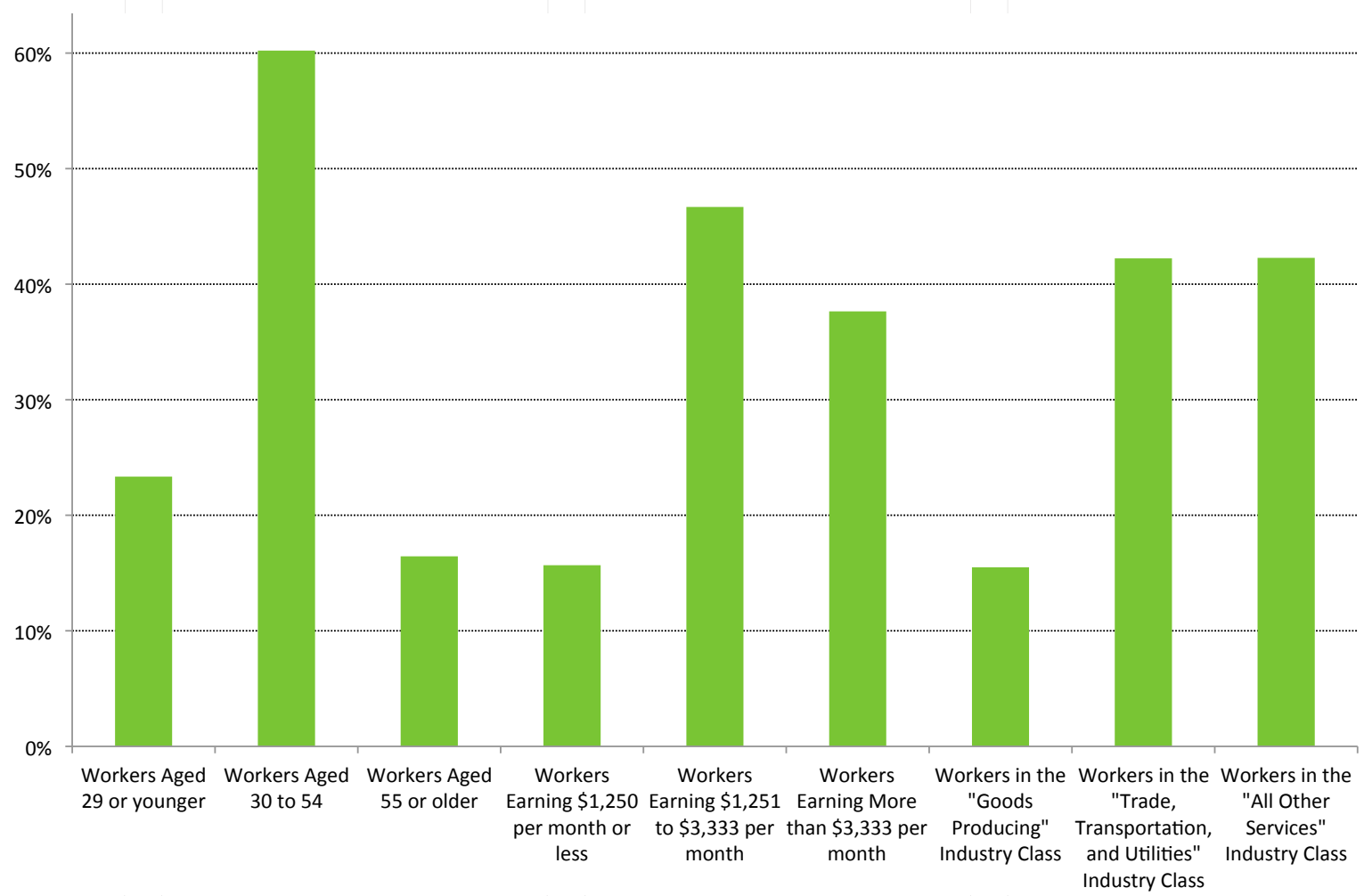

Figure 5. 2010 Arts District Inflow Job Characteristics 
Corridor Los Angeles Report. The report stated that although the majority of the area is zoned for heavy industrial, the use is predominantly light industry and fabrication. The dominant industrial sectors that had the highest growth potential in 2007 were the movie industry, logistics and transportation, printing and publishing, motor freight transportation, and warehousing.

Data from the 2010 Census reveals that wholesale trade, manufacturing, and transportation and warehousing were the top three job sectors in the Arts District. The area accounts for 3,860 jobs with a high percentage of jobs in goods producing, trade, transportation, and utilities. Although the majority of jobs within the Arts District are linked to industrial land uses, there is a demand to convert industrial parcels to non-industrial uses. The demand is due to market forces and the upsurge of development is permitted due to the inclusivity of the Los Angeles Zoning Code. Additionally, there is less oversight in residential development when parcels are rezoned from Heavy Industrial to Commercial Manufacturing or Manufacturing than if developers attempt residential development on an industrially zoned parcel.

According to CBRE Global Research and Consulting, Central Los Angeles, the area where the Arts District is located, accounts for $13 \%$ of the available industrial space for the Greater Los Angeles area, as of 2014. Because of its proximity to Downtown, land that has been converted to non-industrial land uses is worth 29 percent more per square foot. CBRE assessed the lease rate per square foot of industrial land in Central Los Angeles to be approximately $\$ 0.70$. In contrast, rates drop in the City of Vernon and Commerce, cities only several miles away, to $\$ 0.56$ and $\$ 0.50$, respectively. The Arts District continues to experience a transformation in its industrial building stock as adaptive reuse converts available space into alternative uses such as creative office or live/work lofts.

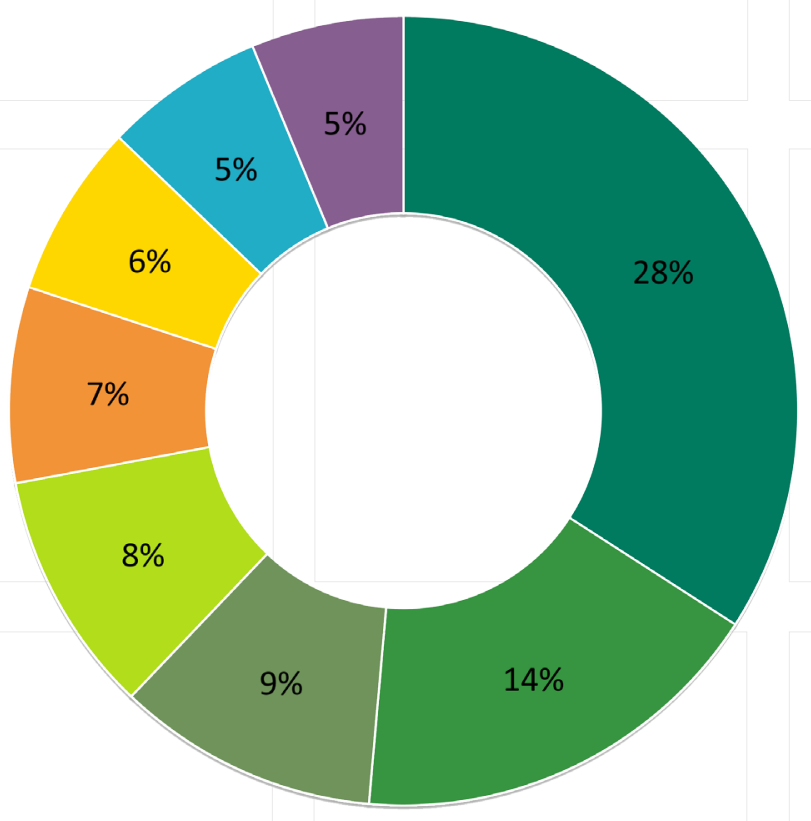

- Wholesale Trade

- Manufacturing

- Transportation and Warehousing

- Other Services (excluding Public Administration)

- Accommodation and Food Services

Educational Services

- Professional, Scientific, and Technical Services

- Retail Trade

Figure 6. 2010 Top 8 Jobs in Arts District by NAICS Industry 


\section{Circulation}

Residents of the Arts District have expressed the need for better public transportation, improved sidewalks and streets, the addition of parking, and enhanced pedestrian and bike networks. Over the last thirty years the Arts District has experienced a vigorous and growing economy. Future developments will almost double the current population. It is therefore necessary to improve circulation and mobility in the Arts District.

\section{Existing Street Conditions}

Streets in the Arts District show remnants of rail lines that protrude from the asphalt around the area. The street network follows the covered tracks of the Los Angeles Railway and electric car routes. The right-ofway varies considerably from street to street and sometimes, block by block. As an example, South Santa Fe Avenue at First Street has a rightof-way of 100 feet, less than half a mile south it narrows to 50 feet after it passes underneath the Fourth Street Bridge. There is a lack of pedestrian infrastructure that spurns from the piecemeal development pattern that has occurred in the area since the 1980s. Improved sidewalks are concentrated around new development or residential conversions. Additionally, some streets have no markings other than a rain gutter that bisects the pavement. The majority of internal streets are classified as collector streets, with the arterials designated Major Highway Class-II or Secondary Highway. Almost all of the streets do not comply with the Public Works Standard Plan for street dimensions. Parking north of Fourth Street is generally marked and is either parallel or angled. Parking in the remainder of the Arts District is haphazard with some areas marked and others improvised.

Right: Inconsistent pedestrian infrastructure along Palmetto Street. One side lacks sidewalks while the other has obstacles within the pedestrian right-of way.

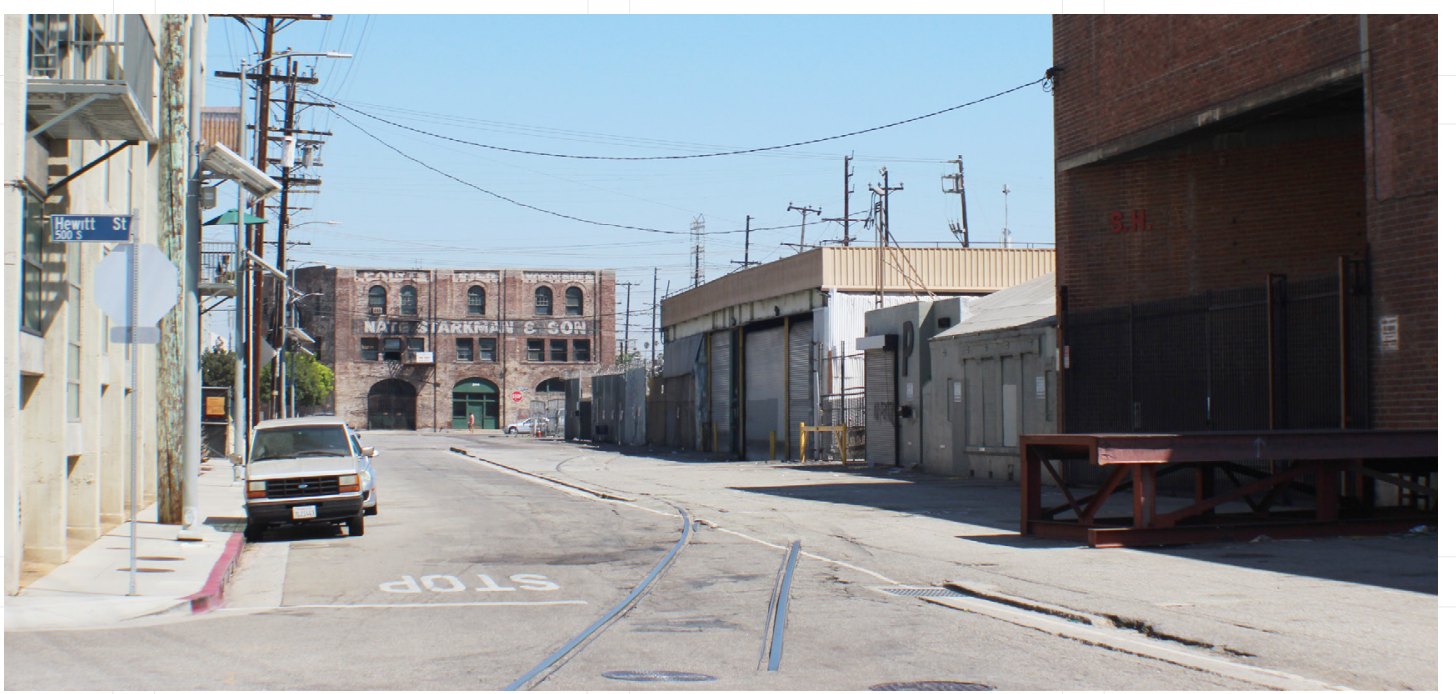


Arts District Street Designations Map

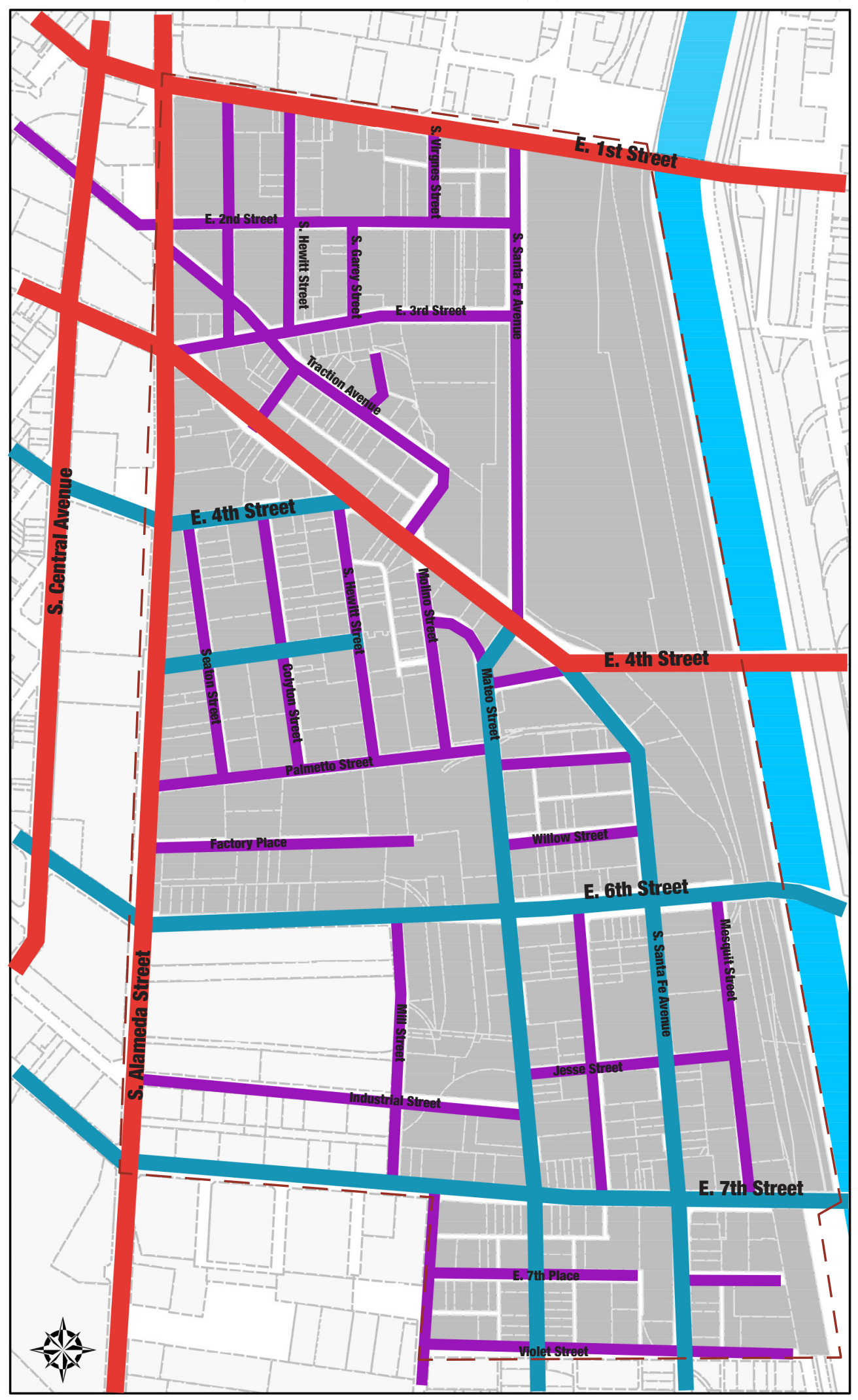

_ Major Highway Class II

- Collector

— Secondary Highway

0
0
0
$\frac{0}{10}$
$D$
$\frac{D}{0}$
$\frac{1}{2}$
$\frac{0}{0}$

Figure 7. Street Designations Map 


\section{$\underline{\text { Transportation }}$}

The area is serviced by LADOT and Metro, but is primarily oriented towards the personal automobile. Proximity to the Metro Gold Line light rail marks the northern portion of the Arts District and makes the area between First and Fourth Street an ideal location for transit-oriented development. LADOT services the area with DASH and has stops along Hewitt Street and Traction Avenue, but those are the only streets the bus runs on as it exits the area along Fourth Street and continues onto Third Street and into Downtown. The remainder of the Arts District has a shortage of internal connectivity due to a lack of transit services traveling north/south. METRO services are concentrated along the major arterials to and from Downtown Los Angeles; this includes First Street, Sixth Street, and Seventh Street. Because of the lack of transit options, automobile use in the area is the primary mode of transportation. Alameda is the major north/south connector for automobiles, and First, Fourth, Sixth, and Seventh Street accommodate east/west automobile traffic. Existing circulation systems are designed to transport automobiles efficiently to Downtown and are not intended to divert traffic into the Arts District.

\section{Pedestrian and Bicycle Mobility}

There is minimal bicycle infrastructure in the Arts District, First and Second Street each have sharrowed bike routes, and Third Street has the only bike lane. There are no bike routes, lanes, or shared-lane markings anywhere else in the Arts District. Pedestrian infrastructure in some areas is substandard and unsafe, with sidewalks that are in disrepair or nonexistent.

Right: A bicyclist rides in a rain gutter along S Hewitt Street. The street has a sidewalk and formal parking south of Fifth Street.

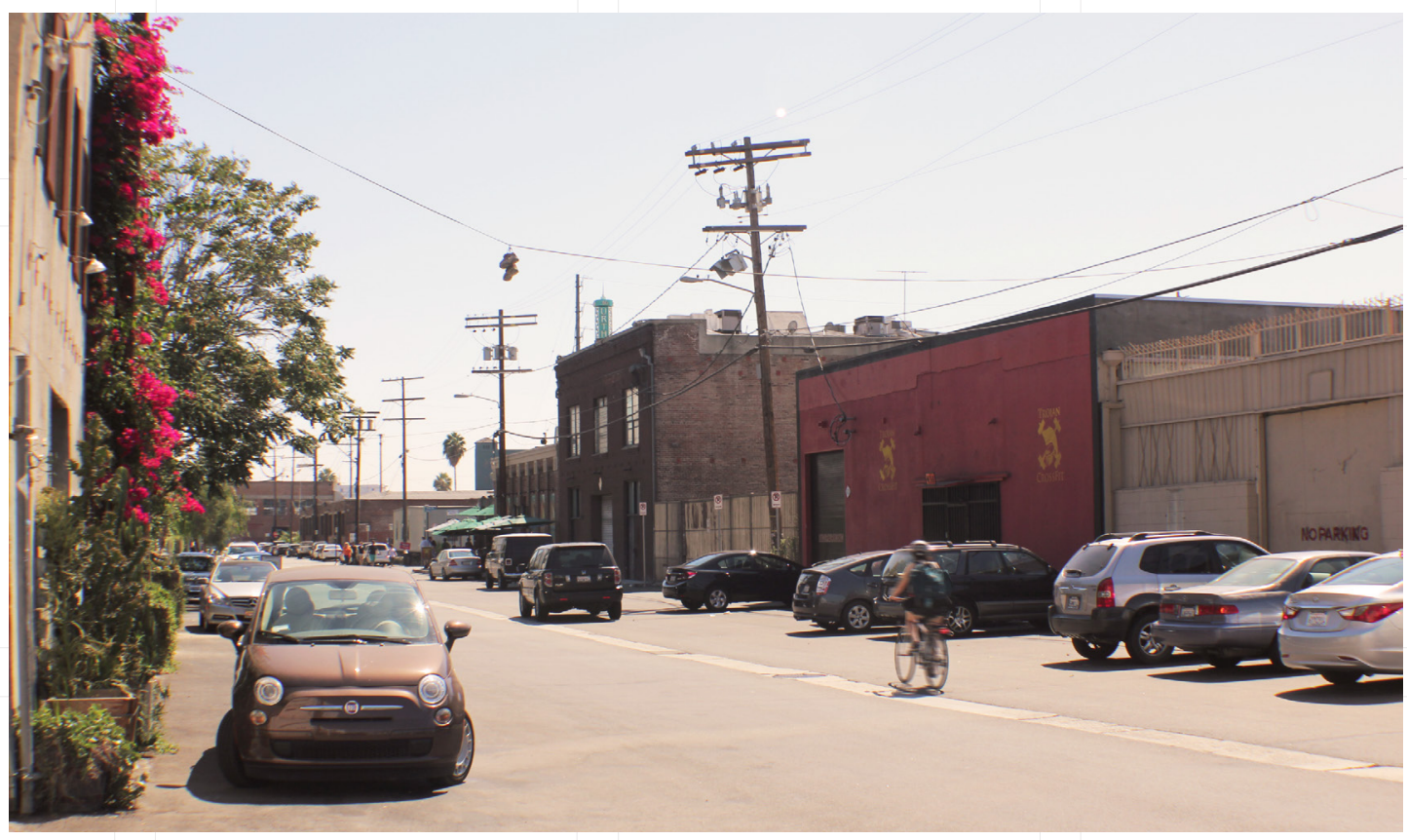




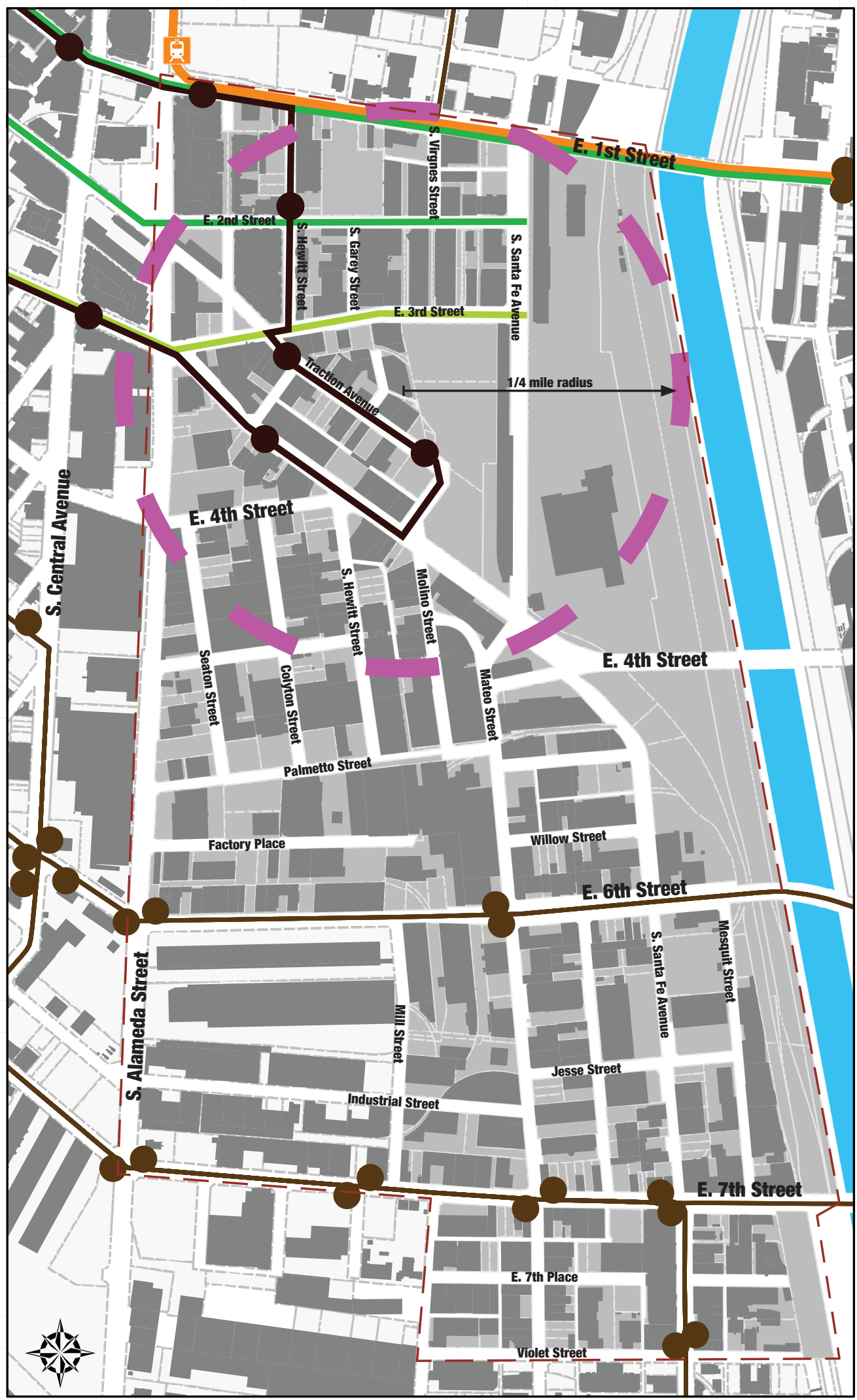

Gold Line Portal

- Metro Gold Line

Metro Bus Stop

- Metro Bus Line

DASH Bus Stop

- DASH Bus Line

- Sharrowed Bike Route Bike Lane

_ 1/4 Mile Walking Radius

— Arts District Boundary

Figure 8. Circulation Map 


\section{Key Challenges and Opportunities}

\section{Challenges}

The lack of internal mobility and the insufficient infrastructure for pedestrians and bicyclists in the Arts District.

New development threatens to alter the urban fabric, scale, character, and unique identity of the Arts District.

The lack of through traffic and visibility for shops and businesses along Third Street and Traction Avenue.

Industrial uses that are at risk from increase in residential development.

Inconsistent development patterns and land uses that creates a challenge for a cohesive land use and mobility plan.

Job retention and creation due to loss of industrial space.

Insufficient public open spaces, green landscaping, and parks.

Lack of local K-12 schools.
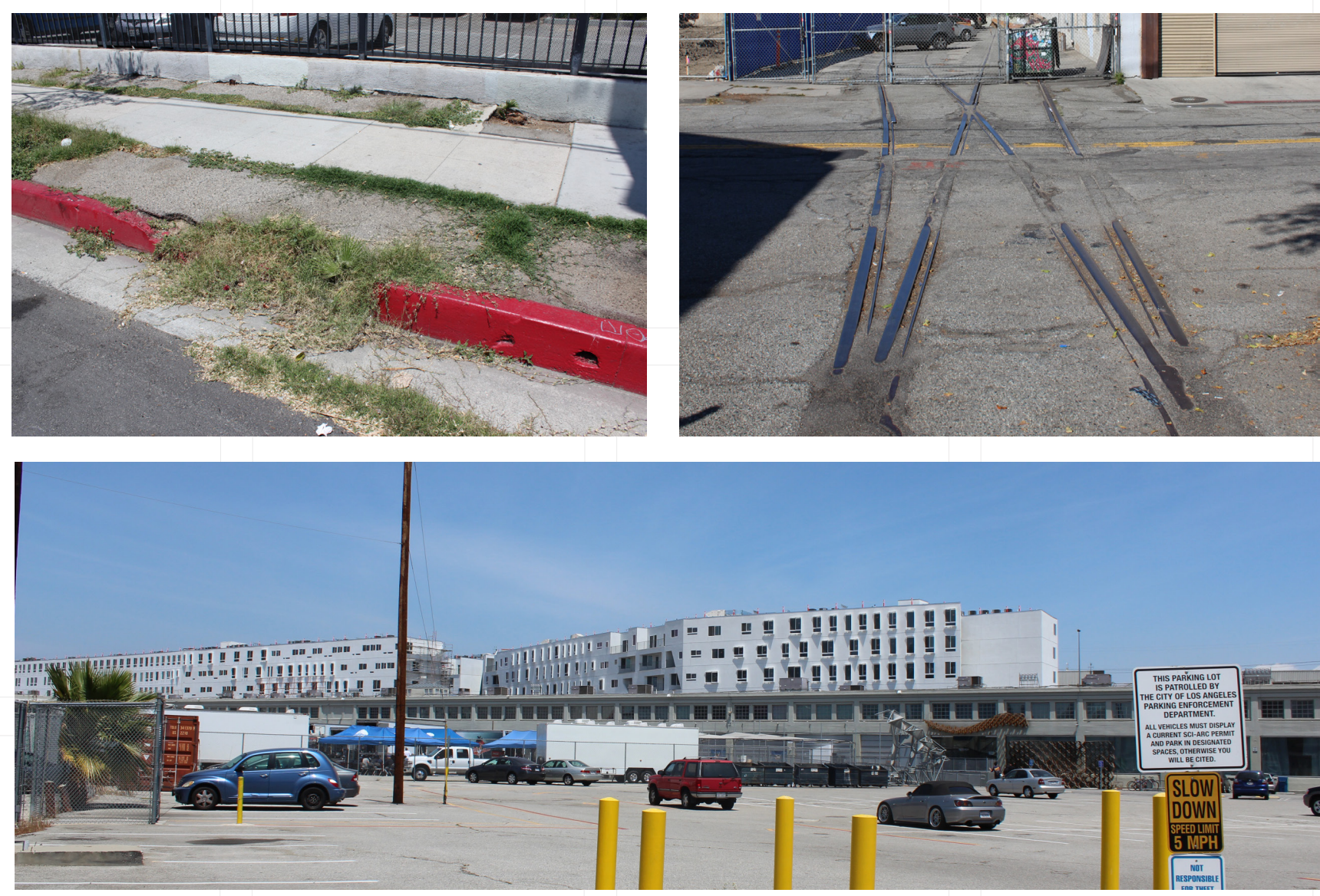


\section{Key Opportunities}

Promote internal circulation with DASH expansion to run east along Third Street, south on Santa Fe, south on Mateo, east on Violet, and to return north along South Santa Fe, west on Fourth Street and into Traction Avenue.

Bike lane expansion from Third Street that will run along S. Santa Fe Avenue into the Sixth Street Viaduct and the Los Angeles River.

Conserve and rehabilitate the historic character of the buildings that define the Arts District as a unique neighborhood.

Promote transit-oriented development north of Forth Street due to its already close proximity to transit in the northern section of the area.

Capitalize on the Arts District's proximity to Downtown Los Angeles.

Utilize parking spaces and lots to create unconventional open and green space in the form of parklets or pocket parks.

Create urban gardening program to rehabilitate homeless population from Skid Row and "green" the area.

Strengthen connection to Fashion District, Boyle Heights, Alameda Corridor and Downtown.
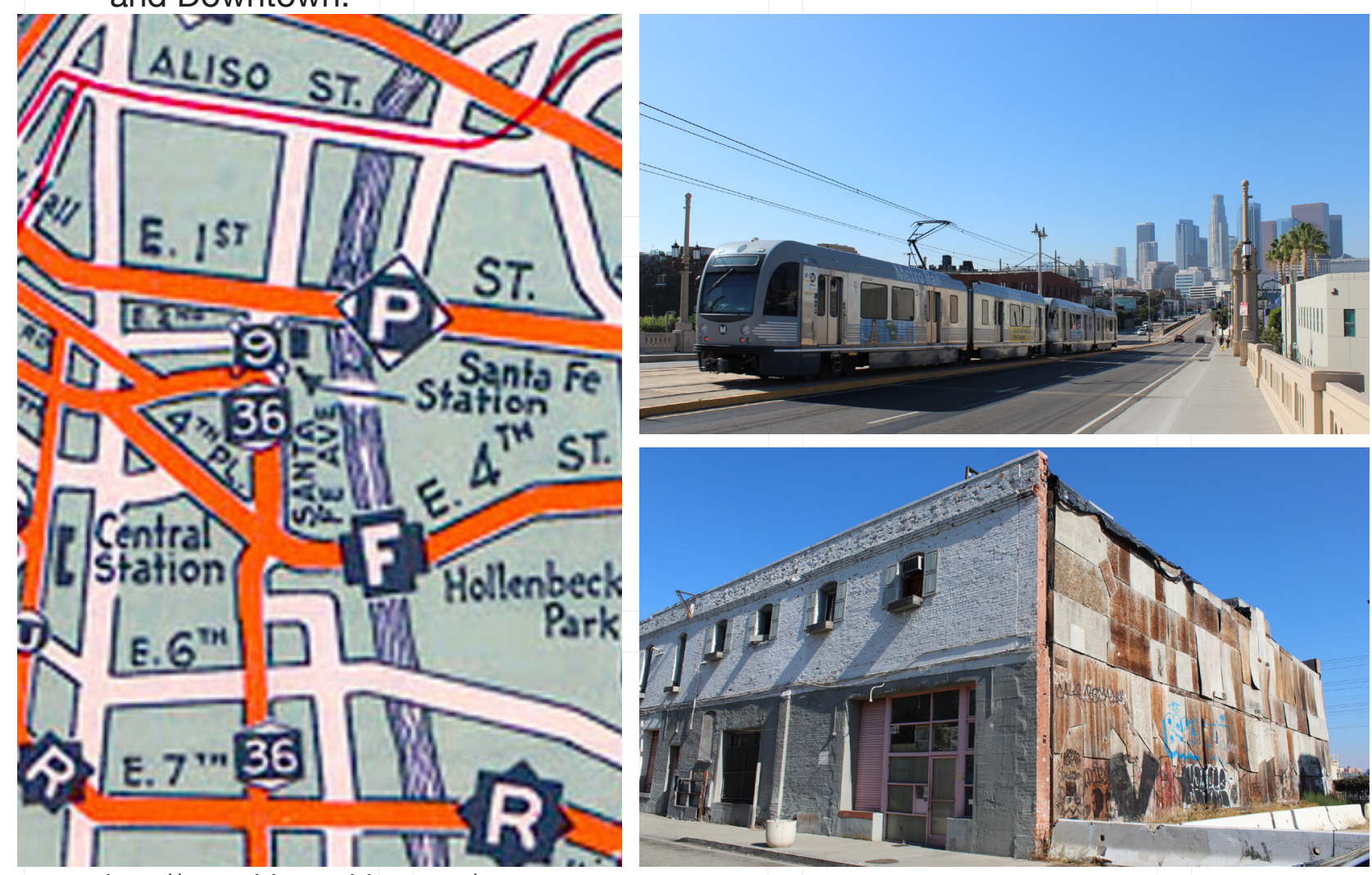

Left: $A 1934$ map of $L A$

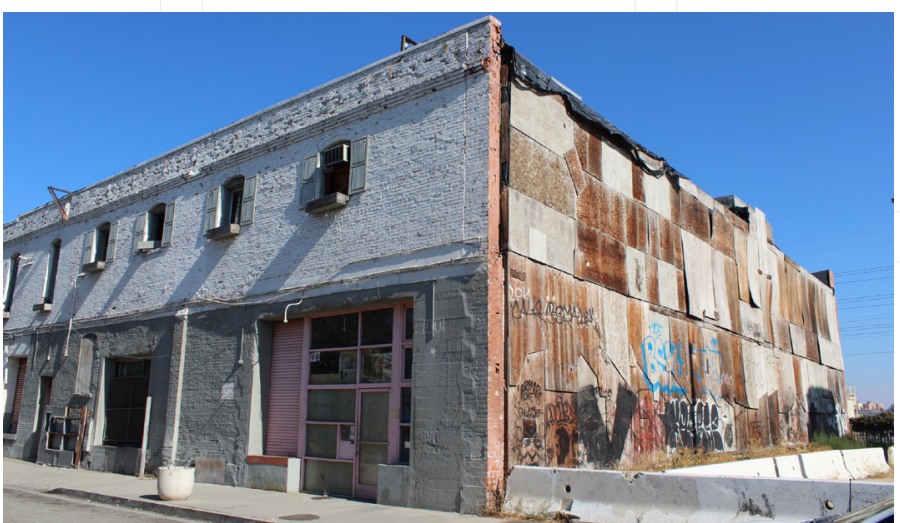

Railway and electric car routes. Top Right: Metro Gold Line runs along first street. Bottom Right: Pickle Works building sits ready for preservation and rehabilitation. 
chapter 3

\section{Form-Based Code}

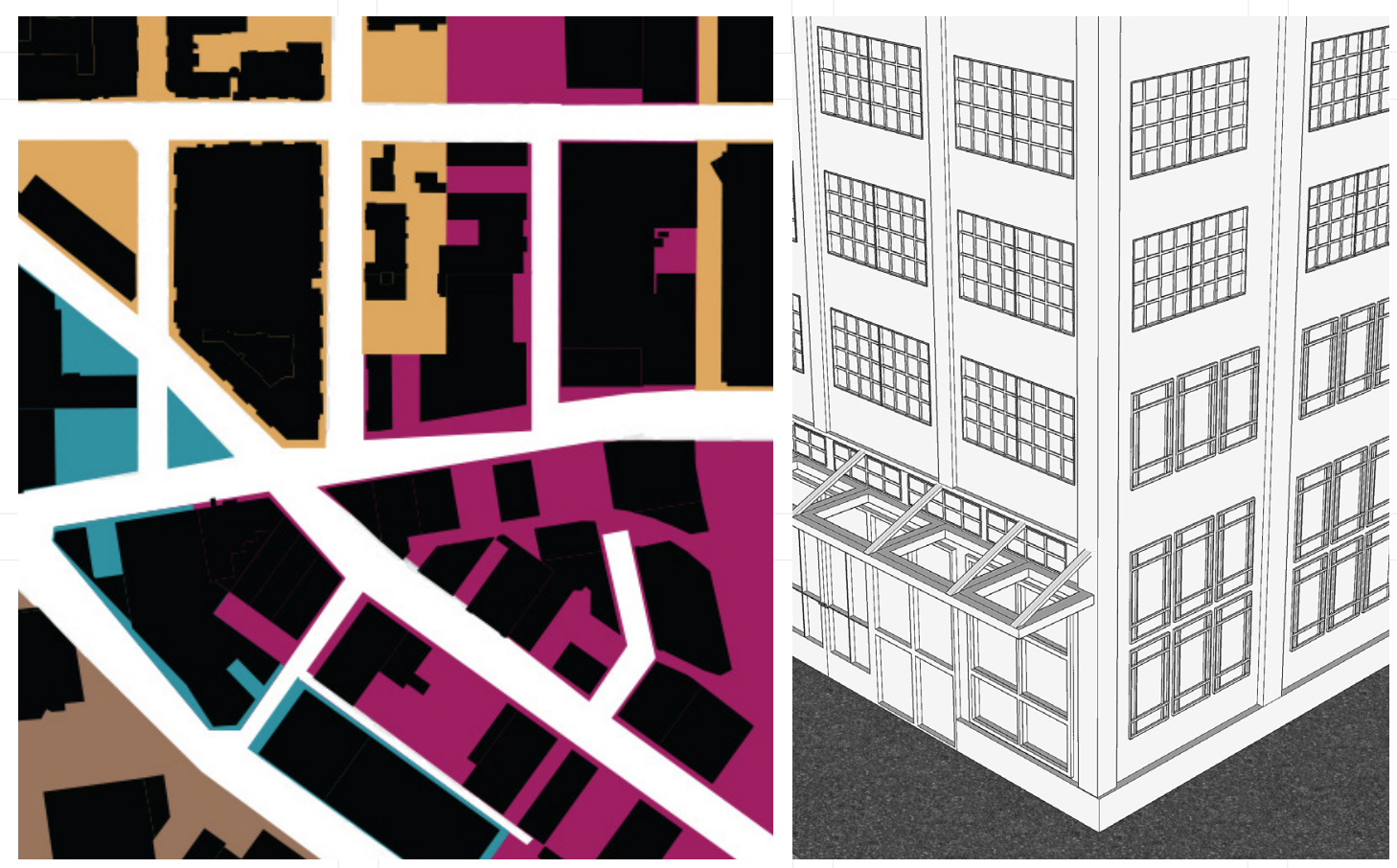

\section{Introduction: A Place Based Approach}

The Regulating Plan will focus on a place-based approach that emphasizes the unique industrial urban character of the Arts District. This chapter defines the regulating framework that illustrates the location of Transect Zones and building form standards that govern the placement, basic character, and mix of land uses. The Form-Based Code reflects the information collected during the site analysis, background, and previous visioning processes.

Due to the unique urban industrial character of the Arts District, only the T5Zone and SD-Zone will be used in this code. Three T5-Zones and two SDZones have been calibrated to fit the Arts District neighborhood. Each of the Transects has a specific intent and general nature yet also reflect features that overlap to create a unified sense of place.

The general intent is that the highest intensity of uses and greatest scale of urban form will be concentrated north of Fourth Street, as this area of the Arts District is closest to the existing Gold Line transit stop. Additionally, the most intense industrial uses will be located on the periphery and southern portion of the area in an effort to agglomerate industry with the adjacent predominantly industrial communities. 


\section{Transect Zone Descriptions}

T5-NO

The intent of the T5-Neighborhood Open Zone is to foster development that supports existing and future public transit within a walkable area.

The general nature consists of a mix of medium-to-high density residential building types, general retail, and small to medium-size services and commercial uses. The Transect supports public transportation alternatives and is ideal for transit-oriented development due to its proximity to existing Gold Line, DASH, and Metro stops.

The open sub-zone supports spill over from the adjacent Transect with an allowance for a larger variety of uses on the ground floor as the area matures into a transit-oriented district over time.

\section{T5-F}

The intent of the T5-Flex Zone is to serve as a focal point for the Arts District and supports the largest variety of land uses.

The general nature consists of vertical and horizontal mixed-use, general retail, service, and some light industrial. The Transect supports a strong urban fabric consistent with shops, cafes, bars, restaurants, and retail establishments on the ground floors and live/work residential space on the upper floors. This zone is designed to exemplify the unique culture of the Arts District as a vibrant, walkable, and regional destination of public art and historical buildings. The regulation of the physical form and uses reflects the historical architecture and the artist community.

\section{T5-N}

The intent of the T5-Neighborhood Zone is to provide a variety of housing options to support industry and business of the adjacent Transects and neighborhoods.

The general nature consists of a diverse mix of high-density residential building types and smaller-size neighborhood support services as a means to provide housing for adjacent land uses. Adaptive reuse of economically struggling industrial buildings is encouraged in the form of residential or live/work development. The building fabric should remain compact and walkable. The character of infill or adaptive reuse development will maintain the industrial design of existing buildings. 

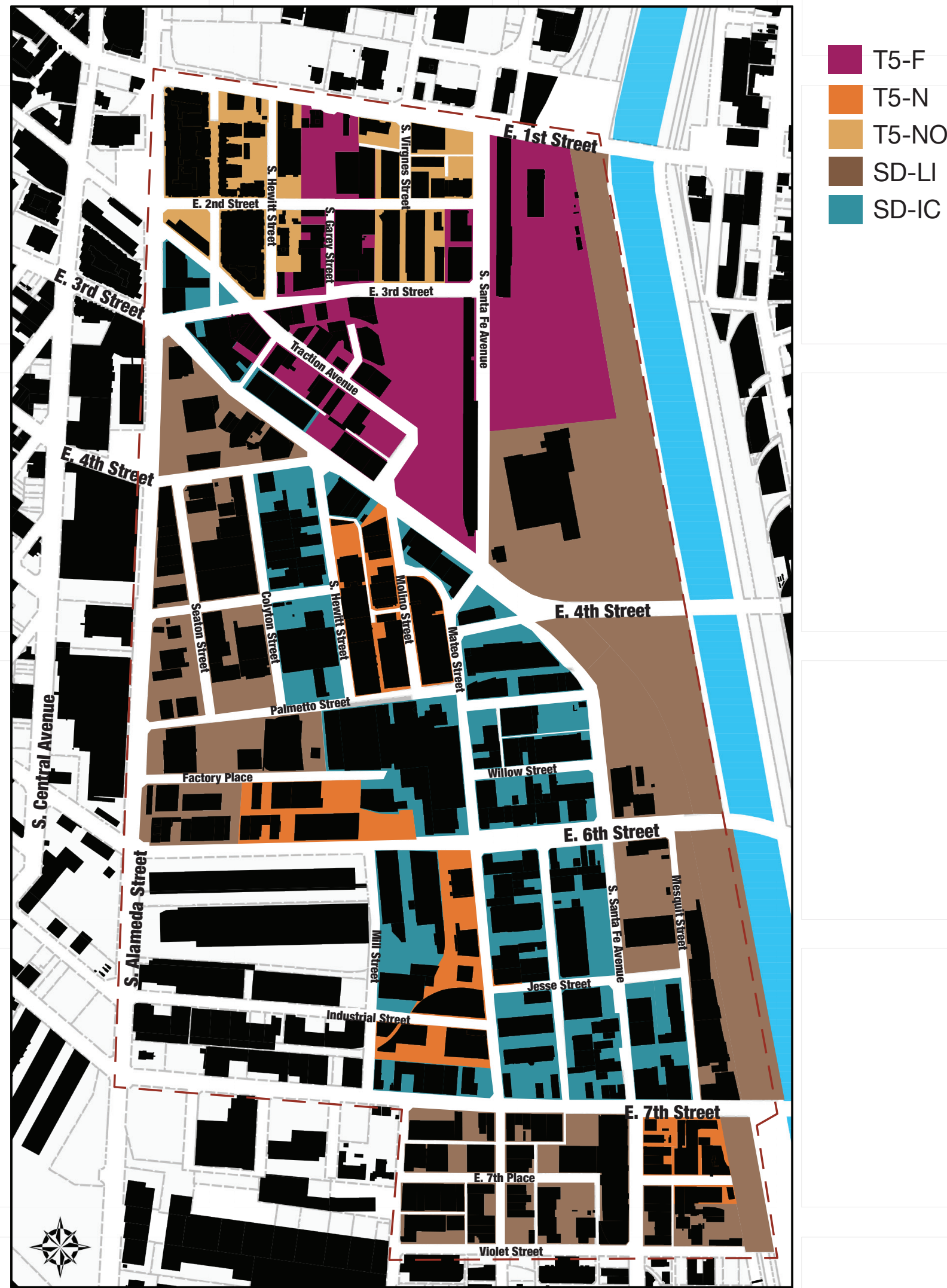

Figure 9. Regulating Plan 


\section{Transect Zone Descriptions}

SD-LI

The intent of the SD-Light Industrial Zone is to incubate innovation by providing a development pattern ideal for new businesses and a Cleantech corridor.

The general nature consists of a variety of building types with small footprints to provide space for light industry uses. Due to the small footprint size of the existing industrial building stock, it is also a suitable location for research institutions, green technology facilities, technology and architecture firms, and smaller scale manufacturing uses. This Transect will serve as a buffer from heavier industrial uses. Its location near the civic, transportation, and business center of downtown, and the surrounding academic institutions and neighborhoods, will serve as a catalyst for a new businesses within the Cleantech corridor.

\section{SD-IC}

The intent of the SD-Industrial Core Zone is to provide medium to largescale industrial space and discourage the expansion of nearby and additional residential uses from adjacent transects.

The general nature consists of a range of industrial activities appropriate for its location, at the edge of the Arts District. It is a zone that is ideal for heaver industrial uses such as manufacturing, processing, storage, and other uses that are not objectionable to adjacent properties from hazards, noise, or other disturbances. 

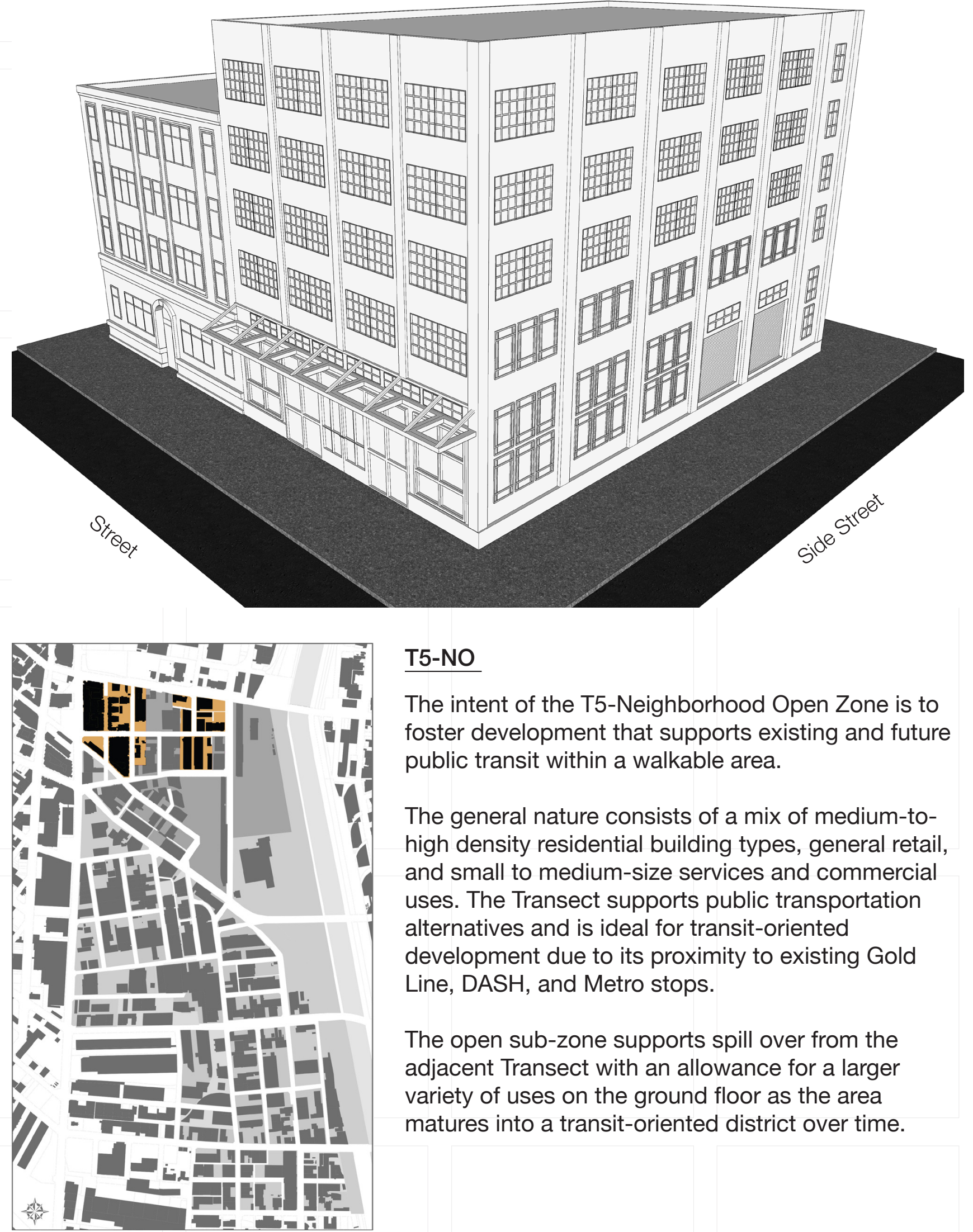

T5-NO

The intent of the T5-Neighborhood Open Zone is to foster development that supports existing and future public transit within a walkable area.

The general nature consists of a mix of medium-tohigh density residential building types, general retail, and small to medium-size services and commercial uses. The Transect supports public transportation alternatives and is ideal for transit-oriented development due to its proximity to existing Gold Line, DASH, and Metro stops.

The open sub-zone supports spill over from the adjacent Transect with an allowance for a larger variety of uses on the ground floor as the area matures into a transit-oriented district over time. 

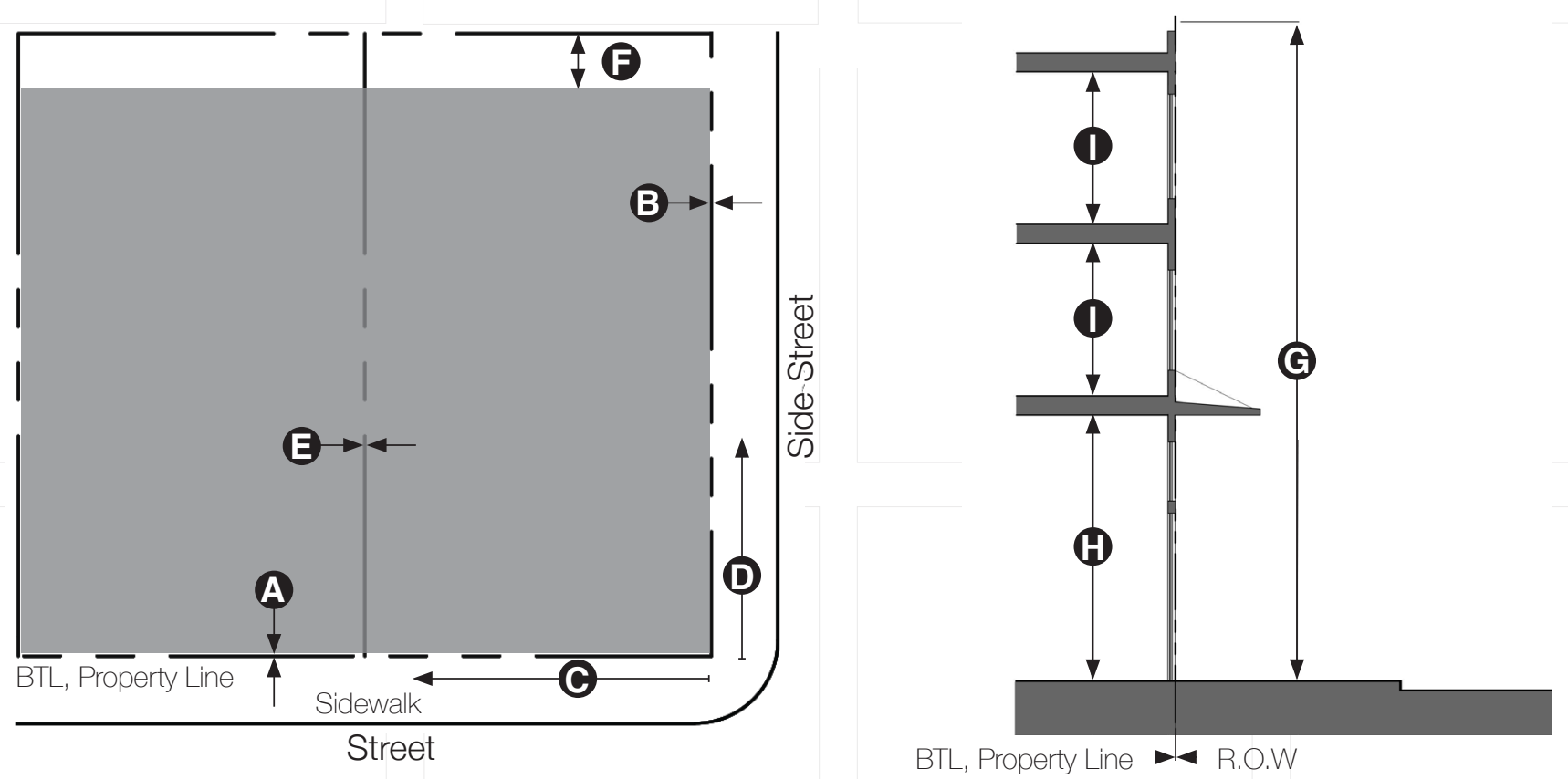

\section{KEY}

- - - - Property Line

Building Area

\begin{tabular}{lll}
\hline $\begin{array}{l}\text { Building Placement } \\
\text { Build-to Line Distance from Property Line }\end{array}$ \\
\hline Front & $0^{\prime}$ (BTL=PL) & A \\
\hline Side Street & $0^{\prime}$ & B \\
\hline BTL Defined by a Building & & \\
Front & $90 \%$ min. & C \\
Side & $60 \%$ min. & D \\
\hline
\end{tabular}

\begin{tabular}{lcl}
\hline Set Back (Distance from Property Line) & \\
\hline Side & $0^{\prime}$ & $\mathbf{E}$ \\
\hline
\end{tabular}

Rear

\begin{tabular}{lll}
\hline Adjacent to T5 Zone & $0^{\prime}$ & ( \\
\hline Adjacent to Any Other Zone & $5^{\prime}$ \\
\hline Building Form & \\
\hline Lot Coverage & $90 \%$ min. \\
\hline
\end{tabular}

Notes

All ground-floor entrances must face the Front or Side Street

\begin{tabular}{|c|c|}
\hline Use & \\
\hline Ground Floor & $\begin{array}{l}\text { Residential, Live/ } \\
\text { Work, General } \\
\text { Retail \& Service* }\end{array}$ \\
\hline Upper Floor(s) & $\begin{array}{l}\text { Residential, Live/ } \\
\text { Work }\end{array}$ \\
\hline${ }^{*}$ See Land Use Table fo & uses. \\
\hline Height & \\
\hline Building Min. & 22' \\
\hline Building Max. & $\begin{array}{l}6 \text { stories } \\
\text { and } 60^{\prime}\end{array}$ \\
\hline Ground Floor Ceiling & $14^{\prime} \mathrm{min}$. \\
\hline Upper Floor(s) Ceiling & $8^{\prime} \mathrm{min}$. \\
\hline
\end{tabular}

\section{Notes}

Within 20' of rear Lot Line, buildings may not be more than a story taller than the allowed height of adjacent buildings. 


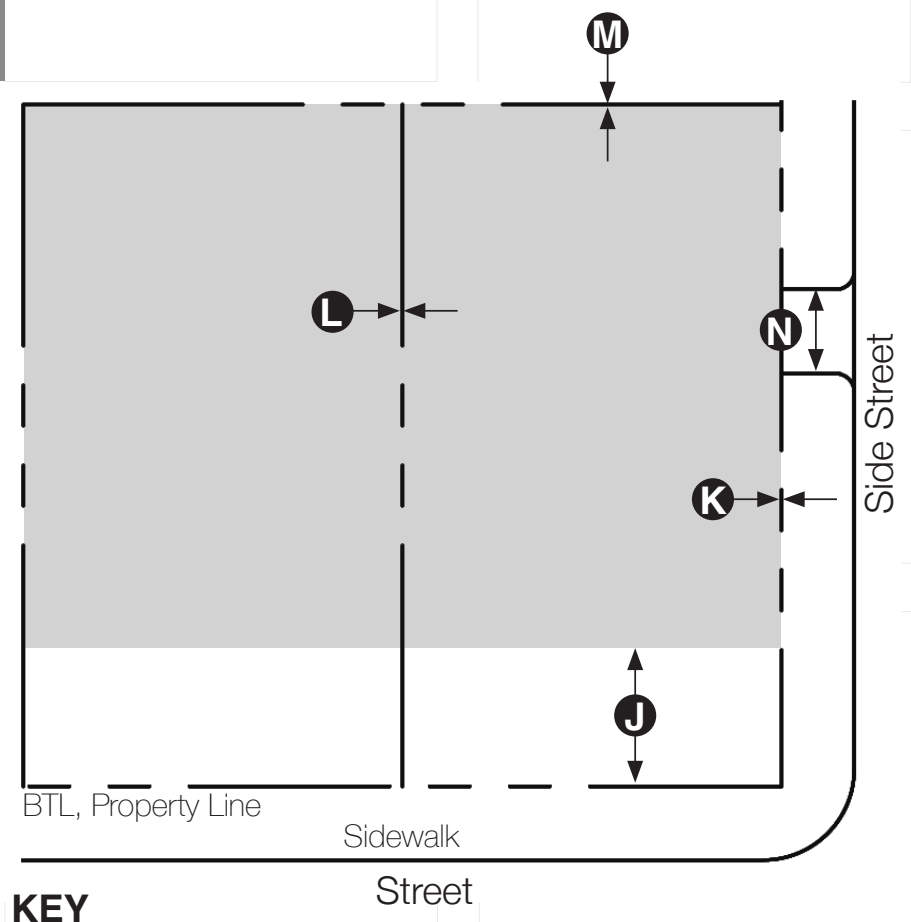

- - - Property Line

Parking Area

\section{Parking}

Location (Distance from Property Line)

\begin{tabular}{lll}
\hline Front Setback & $30^{\prime}$ min. & ( \\
\hline Side Street Setback & 0' min. & ( \\
\hline Side Setback & 0' min. & ( \\
Rear Setback & 0' min. & (U) \\
\hline
\end{tabular}

Curb Cut or Parking Driveway Width

\begin{tabular}{ll}
$\leq 40$ spaces & 14' max. \\
$>40$ spaces & $18^{\prime}$ max. \\
\hline Required Spaces & \\
\hline Ground Floor & \\
Uses $\leq 2,000$ sf & $\begin{array}{l}\text { No off-street } \\
\text { parking required } \\
1 / 1000 \text { sf }\end{array}$ \\
Uses > 2,000 sf & \\
\hline Upper Floors & 1 space/unit \\
Residential & 1 space/1,000 sf \\
\hline Live/Work Units
\end{tabular}

\section{Notes}

A minimum of one bicycle rack place shall be provided per commercial use.

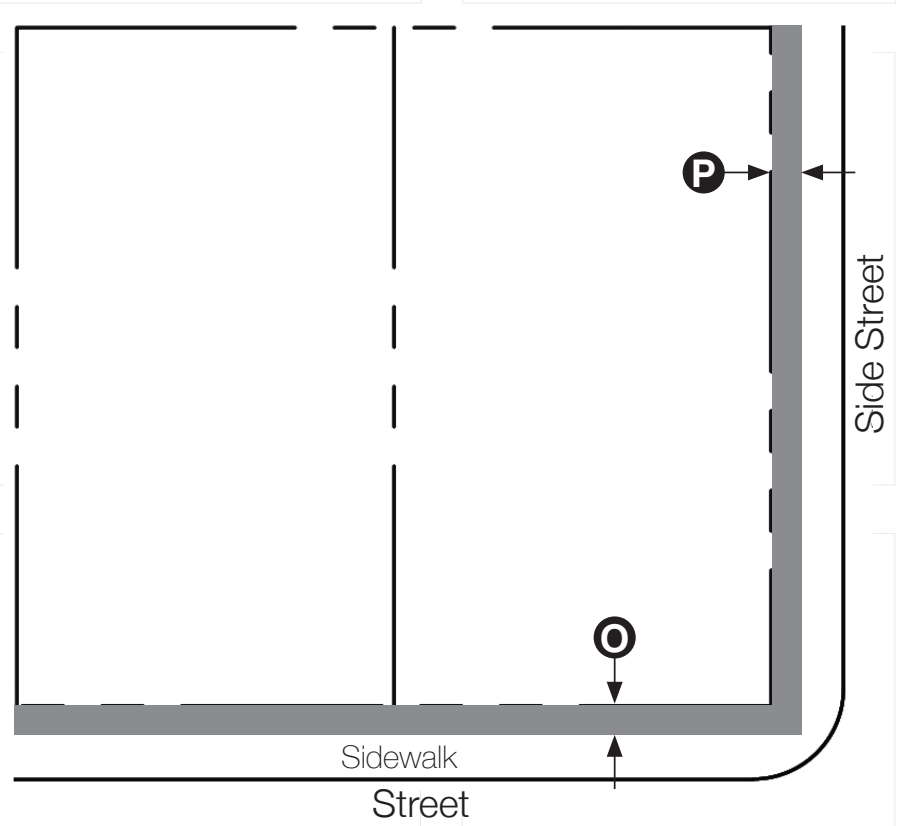

For Residential land uses a min. of 0.10 bicycle spaces/bedroom shall be provided.

In addition a minimum of one bicycle rack place shall be provided within the Public or Private Frontage for every ten vehicular parking spaces.

Parking May be provided off site within 1300' or as shared parking.

Parking encouraged to be underground, aboveground parking lots must be wrapped in active uses. No curb cuts on retail streets or primary pedestrian streets.

\section{Encroachments}

\begin{tabular}{lll} 
Location & & \\
\hline Front & 7' max. & $\mathbf{O}$ \\
\hline Side Street & 7' max. & $\mathbf{P}$ \\
\hline Notes & & \\
\hline
\end{tabular}

Encroachments shall not impede the public right of way, violate the American Disabilities Act, or cause significant risk or conflict with public safety and vehicular traffic.

Sidewalk dining facilities shall be free standing, unattached to the sidewalk, and shall be removed from the sidewalk when the dining facility is not open for business.

See Land Use Table - NO for specific encroachments allowed. 
T5-Neighborhood Open Standards

Table 3. Land Use Neighborhood

\begin{tabular}{l}
\hline Use Type \\
\hline Retail \\
\hline General Retail \\
\hline Neighborhood Market $<10,000 \mathrm{sf}$ \\
\hline Restaurant, Cafe, Coffee Shop \\
Studio: Art, Dance, Music \\
\hline
\end{tabular}

\section{Service}

Bank/Financial Services $\quad<3,500 \mathrm{sf}$

No drive-through services

Automatic Teller Machine

Animal Services

Lodging

Inn, Hotel, Bed \& Breakfast

\section{Residential}

Live/work

Dwelling

Mixed-use Project Residential Component

\section{Notes}

General Retail only allowed on first floor.

\begin{tabular}{l}
\hline Office: Professional $<5,000 \mathrm{sf}$ \\
\hline Transportation \\
\hline Parking Facility: Public or Private \\
\hline Encroachments
\end{tabular}

Eaves, Awnings, Shop Blinds, and Canopies

Signs, Walls

Street Furniture*

Stands or Stalls Displaying

Goods and Services

के

Notes

*Street Furniture shall take up a maximum of 5 ' and not impede the public right of way, violate the American Disabilities Act, or cause significant risk or conflict with public safety and vehicular traffic. 

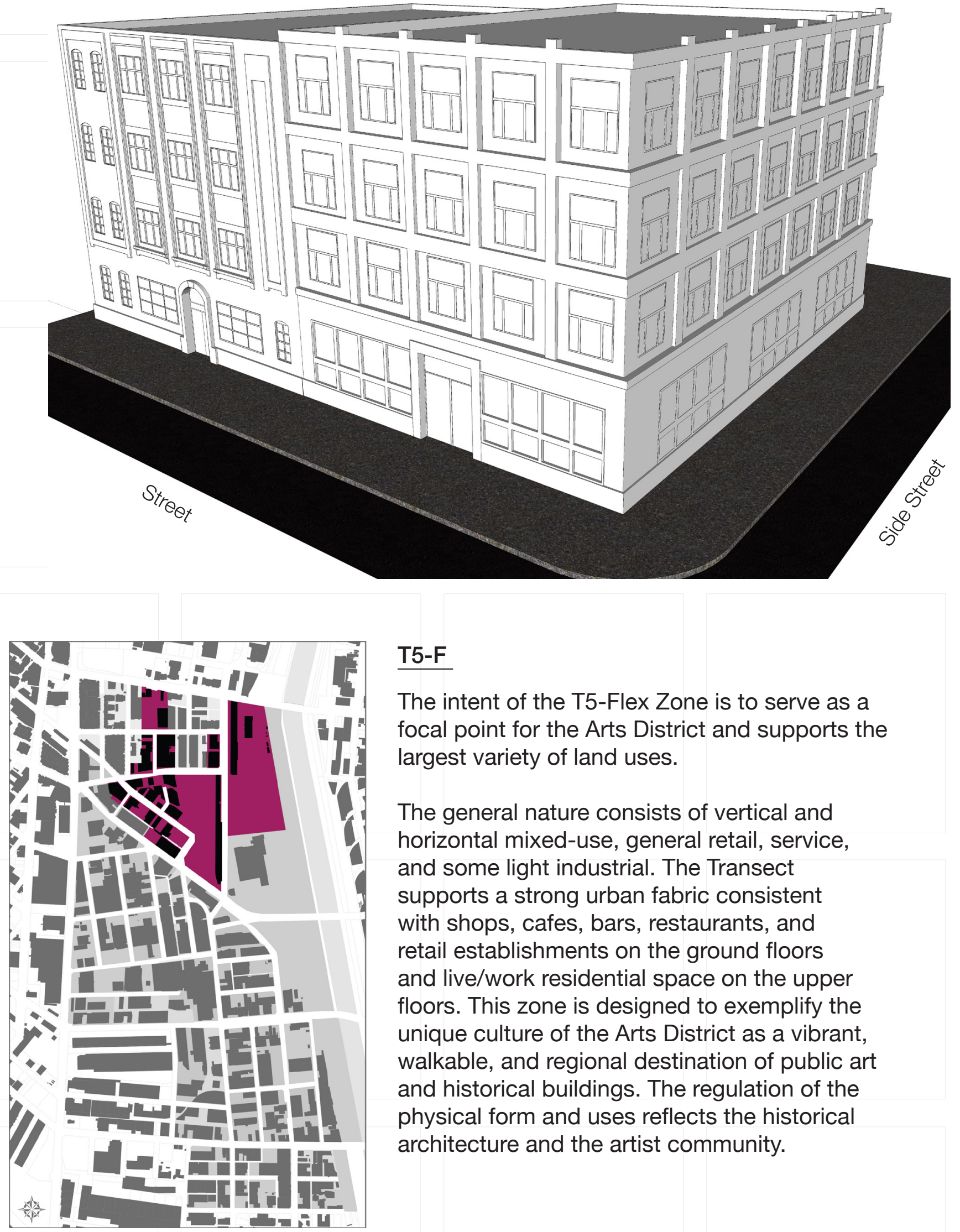

T5-F

The intent of the T5-Flex Zone is to serve as a focal point for the Arts District and supports the largest variety of land uses.

The general nature consists of vertical and horizontal mixed-use, general retail, service, and some light industrial. The Transect supports a strong urban fabric consistent with shops, cafes, bars, restaurants, and retail establishments on the ground floors and live/work residential space on the upper floors. This zone is designed to exemplify the unique culture of the Arts District as a vibrant, walkable, and regional destination of public art and historical buildings. The regulation of the physical form and uses reflects the historical architecture and the artist community. 


\section{T5-Flex Standards}
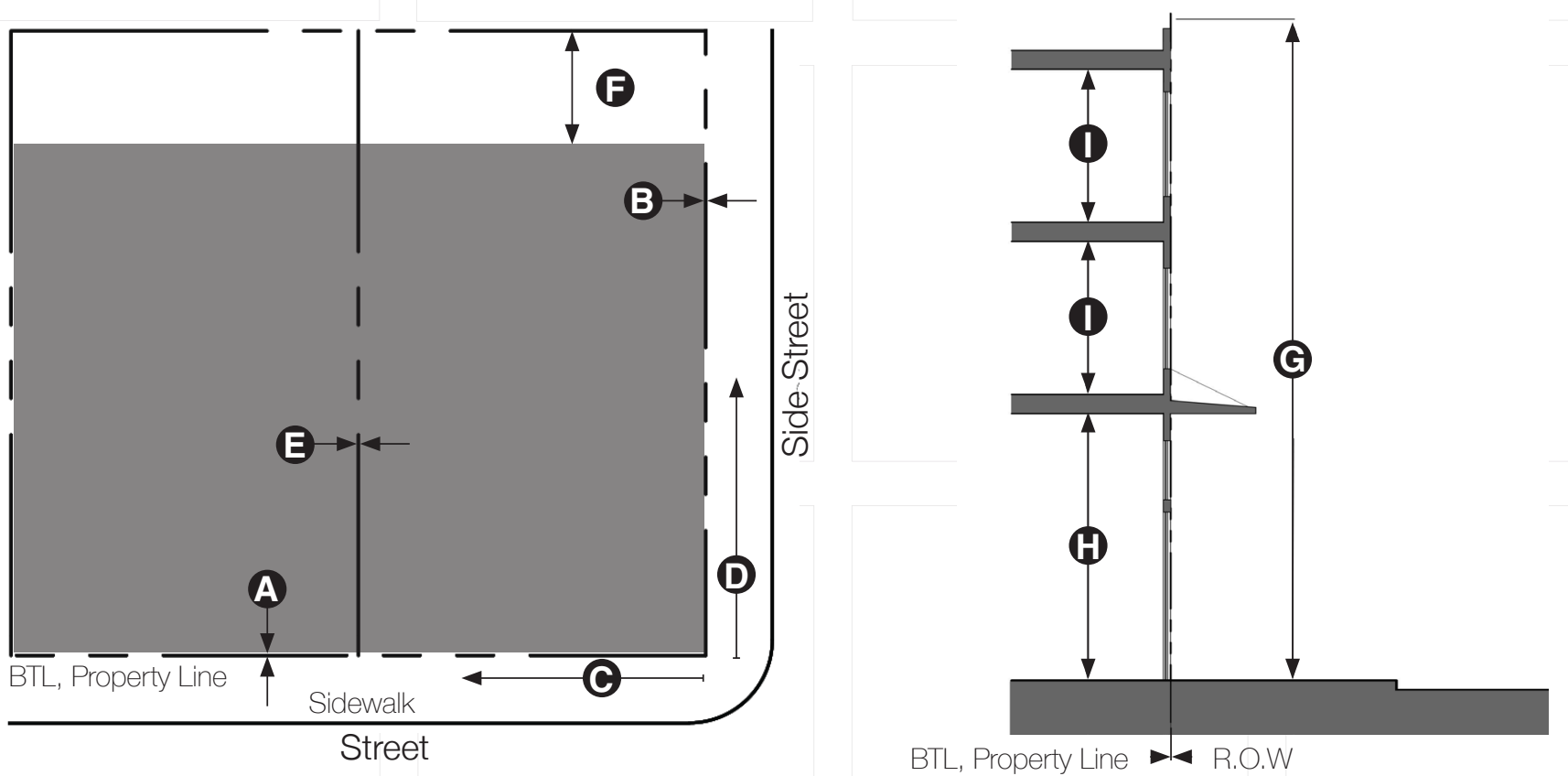

\section{KEY}

- - - Property Line B Building Area

\begin{tabular}{|c|c|c|}
\hline Building Placement & & \\
\hline Build-to Line Distance from & perty Line & \\
\hline Front & $0^{\prime}(\mathrm{BTL}=\mathrm{PL})$ & A \\
\hline Side Street & $0^{\prime}$ & B \\
\hline BTL Defined by a Building & & \\
\hline Front & $80 \% \min$. & C \\
\hline Side & $60 \% \min$. & D \\
\hline Set Back (Distance from Pro & rty Line) & \\
\hline Side & $0^{\prime}$ & $\mathbf{E}$ \\
\hline Rear & & \\
\hline Adjacent to T5 Zone & $0^{\prime}$ & $\boldsymbol{E}$ \\
\hline Adjacent to Any Other Zone & $5^{\prime}$ & \\
\hline Building Form & & \\
\hline Lot Coverage & $80 \% \min$. & \\
\hline
\end{tabular}

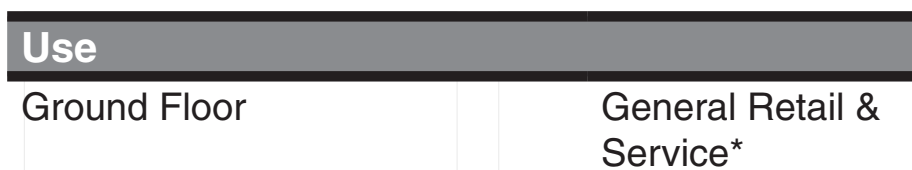

Upper Floor(s)

Residential, Live/

Work, \& Some

General Retail ${ }^{\star}$

*See Land Use Table for specific uses.

\begin{tabular}{lll}
\hline Height & & \\
\hline Building Min. & $22^{\prime}$ & \\
Building Max. & $\begin{array}{l}\text { 6 stories } \\
\text { and 60' }\end{array}$ & G \\
\hline Ground Floor Ceiling & 14' min. & ( \\
\hline Upper Floor(s) Ceiling & 8' min. & ( \\
\hline
\end{tabular}

\section{Notes}

Within 20' of rear Lot Line, buildings may not be more than a story taller than the allowed height of adjacent buildings.

Eating and Drinking establishments are the only General Retail allowed on the second floor.

All ground-floor entrances must face the Front or Side Street 


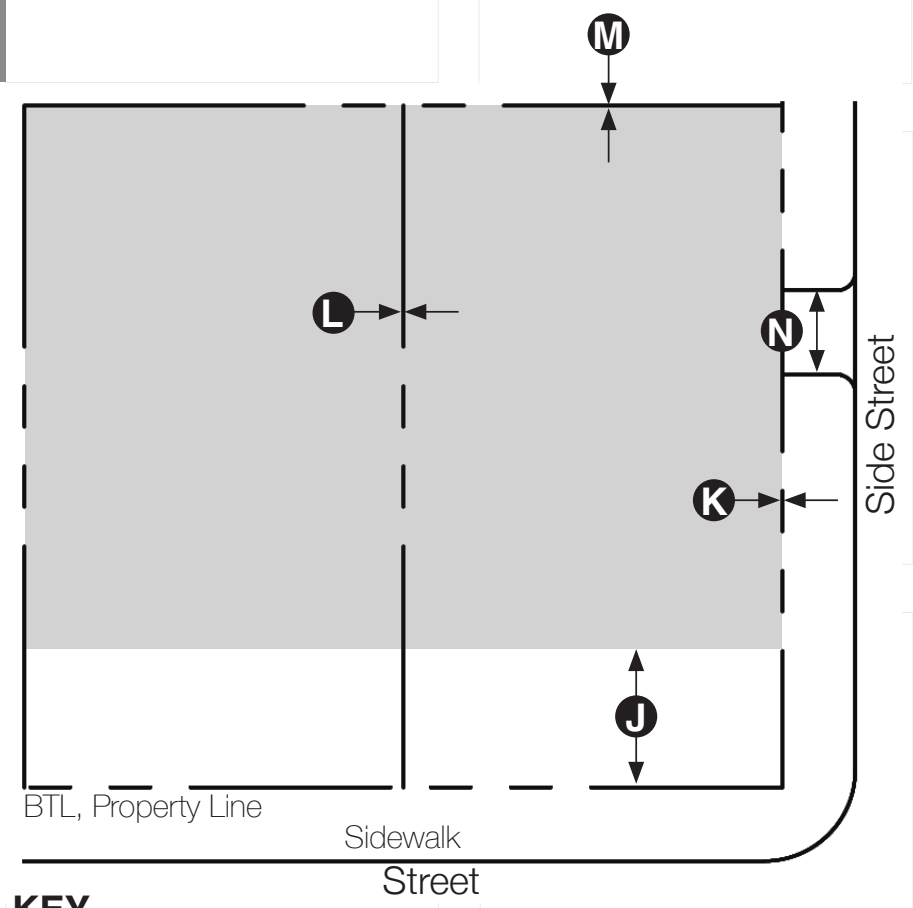

KEY

Parking Area

\section{Parking}

\section{Location (Distance from Property Line)}

\begin{tabular}{lll}
\hline Front Setback & $30^{\prime}$ min. & ( \\
\hline Side Street Setback & 0' min. & ( \\
\hline Side Setback & $0^{\prime}$ min. & ( \\
Rear Setback & 0' min. & (U) \\
\hline
\end{tabular}

Curb Cut or Parking Driveway Width

\begin{tabular}{ll}
$\leq 40$ spaces & $\begin{array}{l}14^{\prime} \text { max. } \\
>40 \text { spaces }\end{array}$ \\
\hline Required Spaces & \\
\hline Ground Floor & \\
Uses $\leq 2,000$ sf & $\begin{array}{l}\text { No off-street } \\
\text { parking required } \\
1 / 1000 \text { sf }\end{array}$ \\
Uses > 2,000 sf & \\
\hline Upper Floors & 1 space/unit \\
Residential & 1 space/1,000 sf \\
\hline
\end{tabular}

\section{Notes}

A minimum of one bicycle rack place shall be provided per commercial use.

For Residential land uses a min. of 0.10 bicycle spaces/bedroom shall be provided.

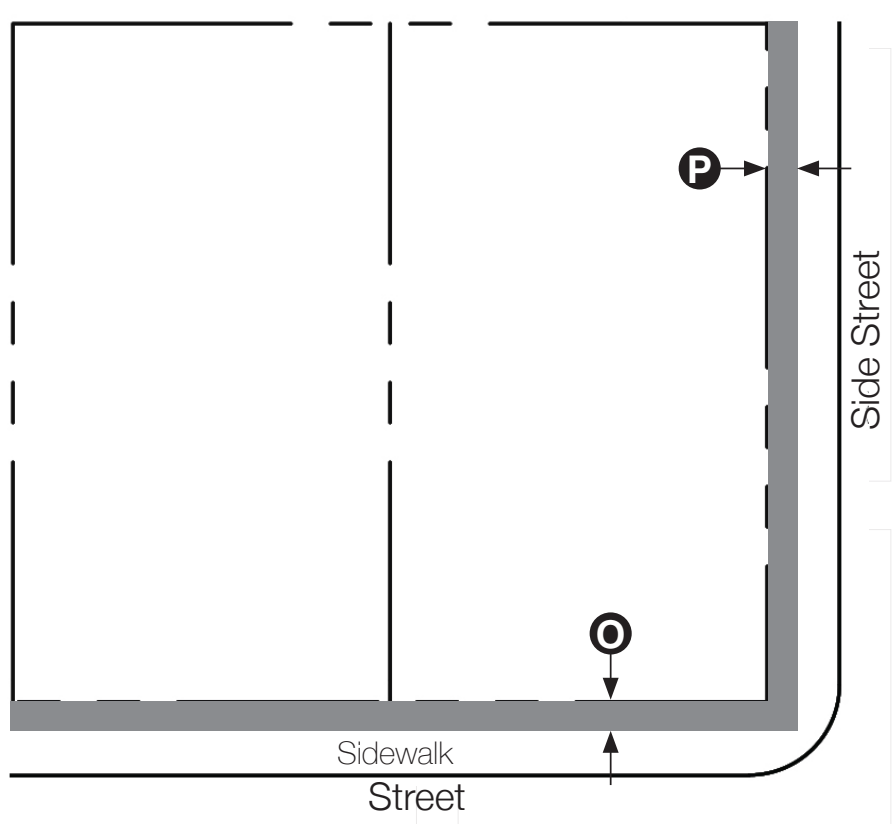

In addition a minimum of one bicycle rack place shall be provided within the Public or Private Frontage for every ten vehicular parking spaces.

Parking May be provided off site within 1300' or as shared parking.

Parking encouraged to be underground, aboveground parking lots must be wrapped in active uses. No curb cuts on retail streets or primary pedestrian streets.

\section{Encroachments}

\section{Location}

\begin{tabular}{lll}
\hline Front & 7' max. & $\mathbf{O}$ \\
\hline Side Street & 7' $\max$. & $\mathbf{P}$ \\
\hline
\end{tabular}

\section{Notes}

Encroachments shall not impede the public right of way, violate the American Disabilities Act, or cause significant risk or conflict with public safety and vehicular traffic.

Sidewalk dining facilities shall be free standing, unattached to the sidewalk, and shall be removed from the sidewalk when the dining facility is not open for business.

See Land Use Table - F for specific encroachments allowed. 


\section{T5-Flex Standards}

Table 4. Land Use Flex

\begin{tabular}{l} 
Use Type \\
Retail \\
\hline Bar, Pub, Tavern, Night Club \\
\hline Neighborhood Market $<10,000$ sf \\
\hline Restaurant, Cafe, Coffee Shop \\
Studio: Art, Dance, Music \\
\hline
\end{tabular}

\section{Service}

Bank/Financial Services $\quad<3,500 \mathrm{sf}$

No drive-through services

Automatic Teller Machine

Animal Services

Lodging

Inn, Hotel, Bed \& Breakfast

\section{Residential}

Live/work ${ }^{2}$

Dwelling $^{2}$

Mixed-use Project Residential Component ${ }^{2}$

Notes

General Retail only allowed on first and second floors.

${ }^{2}$ Allowed only on upper floors or behind ground floor use.

\begin{tabular}{ll}
\hline Office: Professional & $<5,000 \mathrm{sf}$ \\
\hline Industrial (Light) & \\
\hline Media Production \\
Research and Development
\end{tabular}

Wholesaling and Distribution $^{2} \quad<5,000$ sf Must have retail frontage

\section{Transportation}

Parking Facility: Public or Private

\begin{tabular}{|c|}
\hline Encroachments \\
\hline $\begin{array}{l}\text { Eaves, Awnings, Shop Blinds, } \\
\text { and Canopies }\end{array}$ \\
\hline Signs, Walls \\
\hline Street Furniture* \\
\hline $\begin{array}{l}\text { Stands or Stalls Displaying } \\
\text { Goods and Services }\end{array}$ \\
\hline Notes \\
\hline $\begin{array}{l}\text { *Street Furniture shall take up a maximum of } 5 \text { ' } \\
\text { and not impede the public right of way, violate the } \\
\text { American Disabilities Act, or cause significant risk } \\
\text { or conflict with public safety and vehicular traffic. }\end{array}$ \\
\hline
\end{tabular}




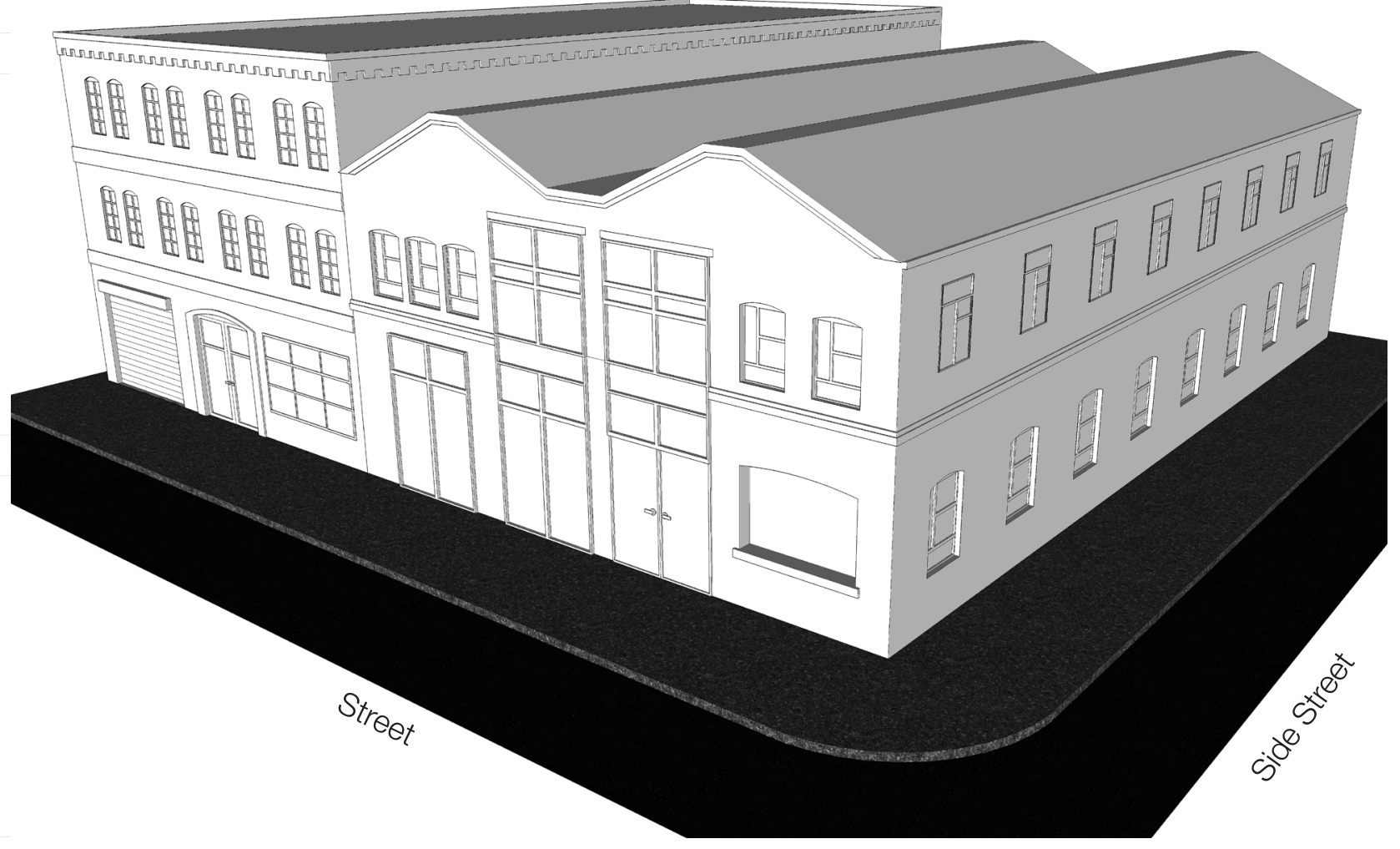

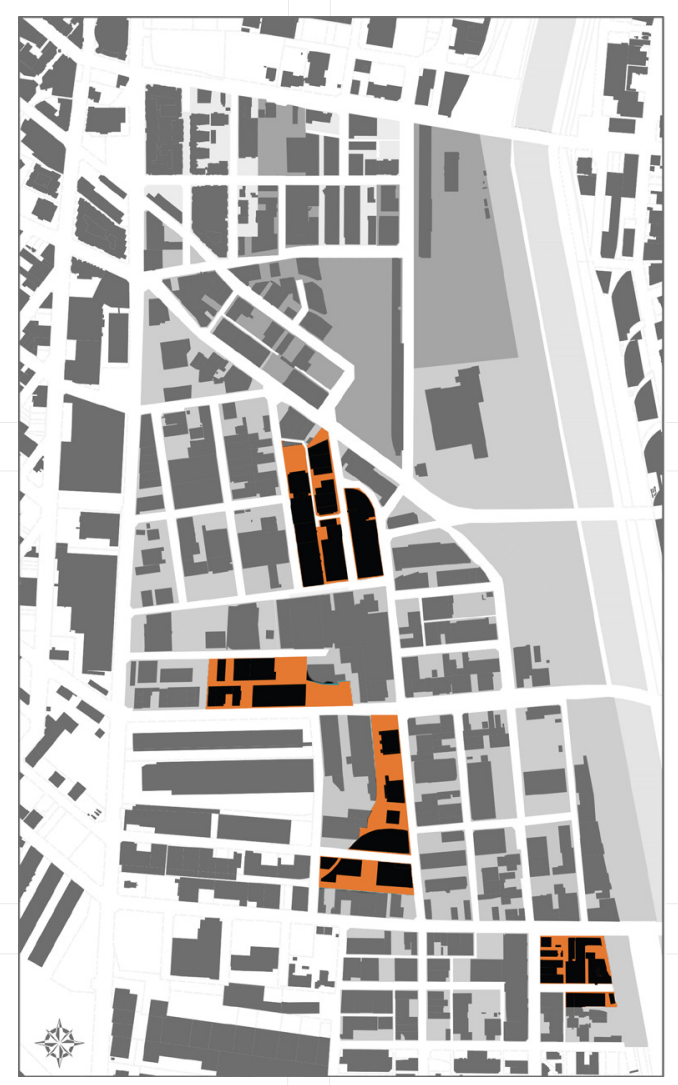

T5-N

The intent of the T5-Neighborhood Zone is to provide a variety of housing options to support industry and business of the adjacent Transects and neighborhoods.

The general nature consists of a diverse mix of high-density residential building types and smaller-size neighborhood support services as a means to provide housing for adjacent land uses. Adaptive reuse of economically struggling industrial buildings is encouraged in the form of residential or live/work development. The building fabric should remain compact and walkable. The character of infill or adaptive reuse development will maintain the industrial design of existing buildings. 

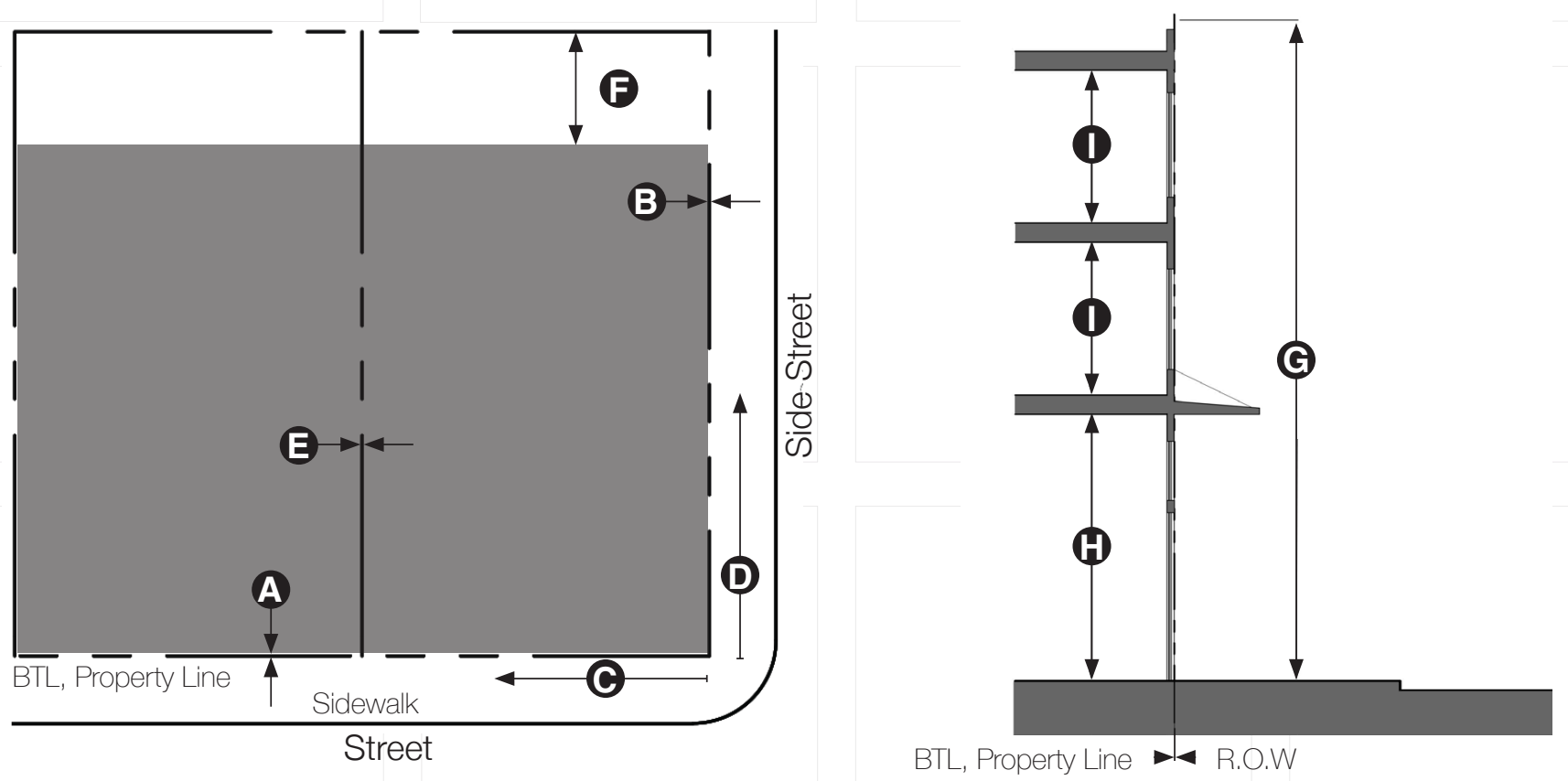

\section{KEY}

- - - - Property Line Building Area

\begin{tabular}{lll}
\hline Building Placement & & \\
\hline Build-to Line Distance from Property Line & \\
\hline Front & $0^{\prime}(\mathrm{BTL}=\mathrm{PL})$ & $\mathbf{A}$ \\
\hline Side Street & $0^{\prime}$ & $\mathbf{B}$ \\
\hline
\end{tabular}

BTL Defined by a Building

Front

$75 \% \min$.

Side

$55 \% \min$.

\begin{tabular}{lcl}
\hline Set Back (Distance from Property Line) & \\
\hline Side & $0^{\prime}$ & E \\
\hline
\end{tabular}

Rear

\begin{tabular}{lll}
\hline Adjacent to T5 Zone & 0 & $\boldsymbol{B}$ \\
\hline Adjacent to Any Other Zone & $5^{\prime}$ & \\
\hline Building Form & & \\
\hline Lot Coverage & $80 \% \mathrm{~min}$. \\
\hline
\end{tabular}

Notes

All ground-floor entrances must face the Front or Side Street

\begin{tabular}{ll}
\hline Use & Residential, \\
Ground Floor & Live/ Work, \\
& Neighborhood \\
& Service \& Retail \\
\hline Upper Floor(s) & Residential, Live/ \\
& Work $^{*}$
\end{tabular}

*See Land Use Table - $\mathrm{N}$ for specific uses.

\begin{tabular}{lll}
\hline Height & & \\
\hline Building Min. & $20^{\prime}$ & \\
Building Max. & $\begin{array}{l}\text { 6 stories } \\
\text { and 60' }\end{array}$ & G \\
\hline Ground Floor Ceiling & 12' min. & ( \\
\hline Upper Floor(s) Ceiling & 8' min. & D \\
\hline
\end{tabular}

\section{Notes}

Within 20' of rear Lot Line, buildings may not be more than a story taller than the allowed height of adjacent buildings. 


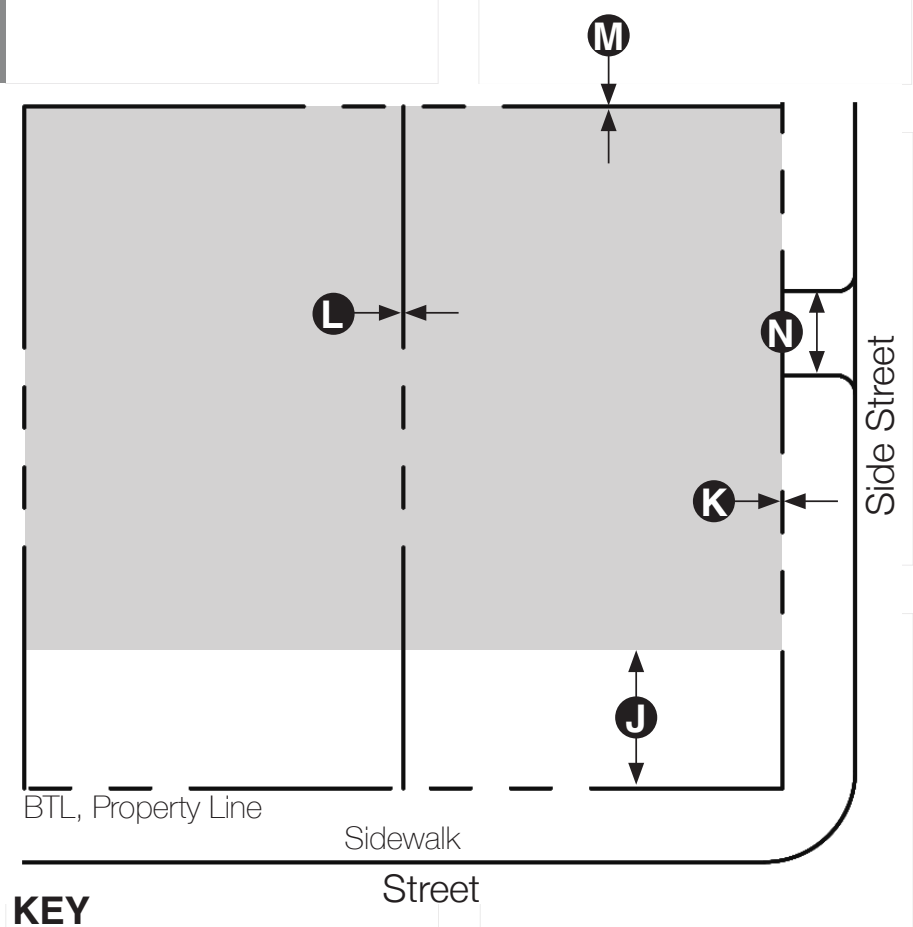

- - - Property Line

Parking Area

\section{Parking}

\section{Location (Distance from Property Line)}

\begin{tabular}{lll}
\hline Front Setback & $30^{\prime}$ min. & ( \\
\hline Side Street Setback & 0' min. & ( \\
\hline Side Setback & 0' min. & ( \\
Rear Setback & 0' min. & (U) \\
\hline
\end{tabular}

Curb Cut or Parking Driveway Width

$\begin{array}{ll}\leq 40 \text { spaces } & 14^{\prime} \max . \\ >40 \text { spaces } & 18^{\prime} \text { max. }\end{array}$

\section{Required Spaces}

\section{Residential Uses}

Residential

Loft

Live/Work Units

\section{Other Uses}

Uses $\leq 2,000 \mathrm{sf}$

Uses $>2,000 \mathrm{sf}$

\section{Notes}

A minimum of one bicycle rack place shall be provided per commercial use.

\section{Arts District Form-Based Code}

No off-street parking required $1 / 1000 \mathrm{sf}$

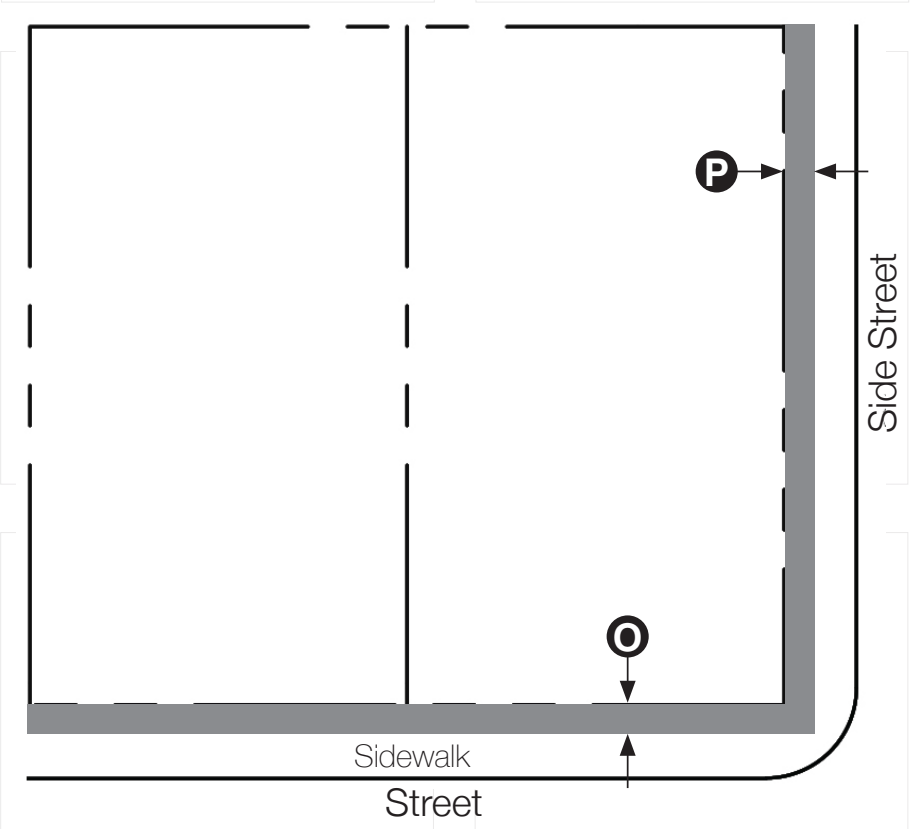

For Residential land uses a min. of 0.10 bicycle spaces/bedroom shall be provided.

In addition a minimum of one bicycle rack place shall be provided within the Public or Private Frontage for every ten vehicular parking spaces.

Parking May be provided off site within 1300' or as shared parking.

Parking encouraged to be underground, aboveground parking lots must be wrapped in active uses. No curb cuts on retail streets or primary pedestrian streets.

\section{Encroachments}

\section{Location}

\begin{tabular}{lll}
\hline Front & 7' max. & $\mathbf{O}$ \\
\hline Side Street & 7' max. & $\mathbf{P}$ \\
\hline Notes & &
\end{tabular}

Encroachments shall not impede the public right of way, violate the American Disabilities Act, or cause significant risk or conflict with public safety and vehicular traffic.

Sidewalk dining facilities shall be free standing, unattached to the sidewalk, and shall be removed from the sidewalk when the dining facility is not open for business.

See Land Use Table - $\mathrm{N}$ for specific encroachments allowed. 
T5-Neighborhood Standards

Table 5. Land Use Neighborhood

\begin{tabular}{l}
\hline Use Type \\
\hline Retail \\
\hline $\begin{array}{l}\text { Neighborhood Market/Convenience Store }<10,000 \\
\text { sf }\end{array}$ \\
\hline Restaurant, Cafe, Coffee Shop $<10,000 \mathrm{sf}$ \\
Studio: Art, Dance, Music \\
\hline Residential \\
\hline Live/work \\
Dwelling \\
Mixed-use Project Residential Component \\
\hline
\end{tabular}

\section{Service}

Automatic Teller Machine

Lodging

Inn, Hotel, Bed \& Breakfast

Transportation

Parking Facility: Public or Private

Encroachments

Eaves, Awnings, Shop Blinds, and Canopies

Signs, Walls

Street Furniture*

\section{Notes}

*Street Furniture shall take up a maximum of 5' and not impede the public right of way, violate the American Disabilities Act, or cause significant risk or conflict with public safety and vehicular traffic. 


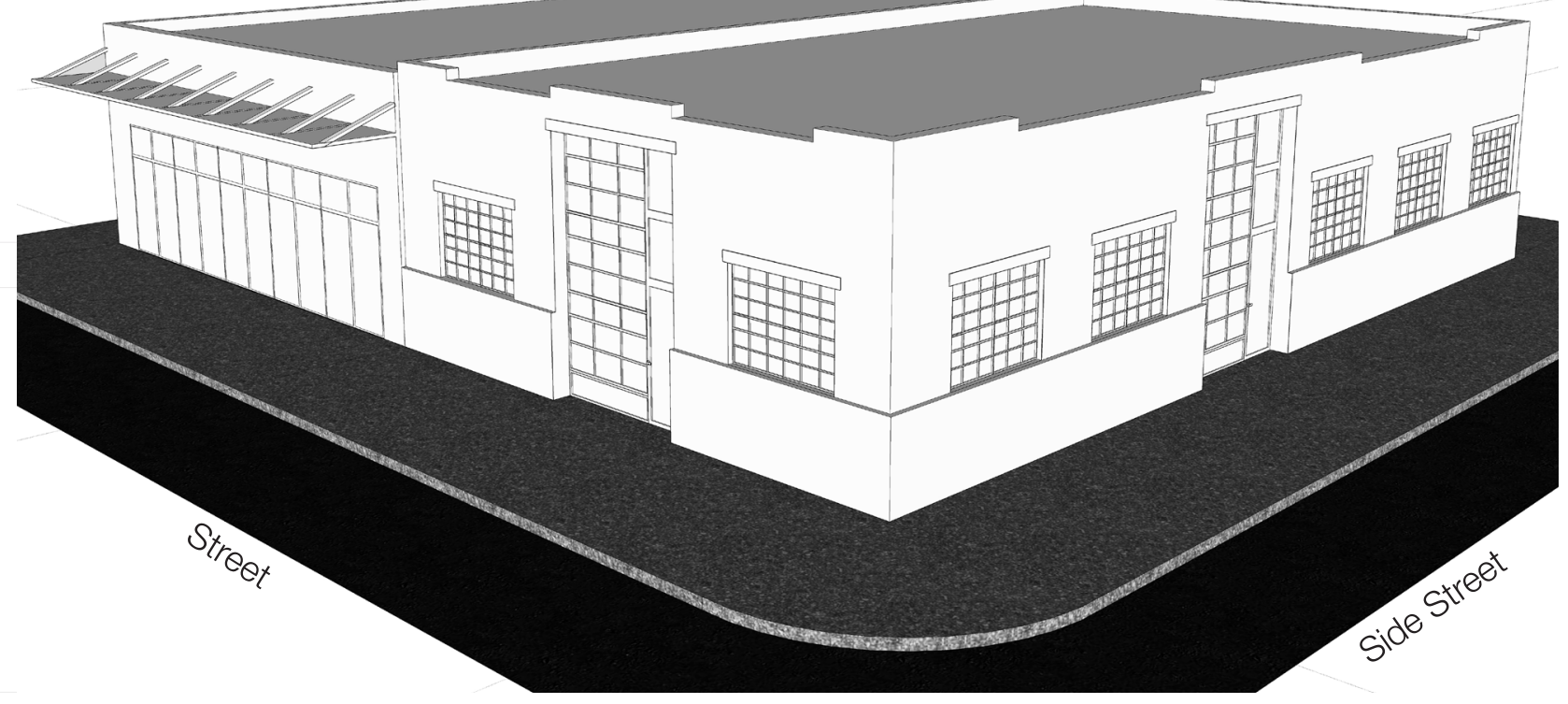

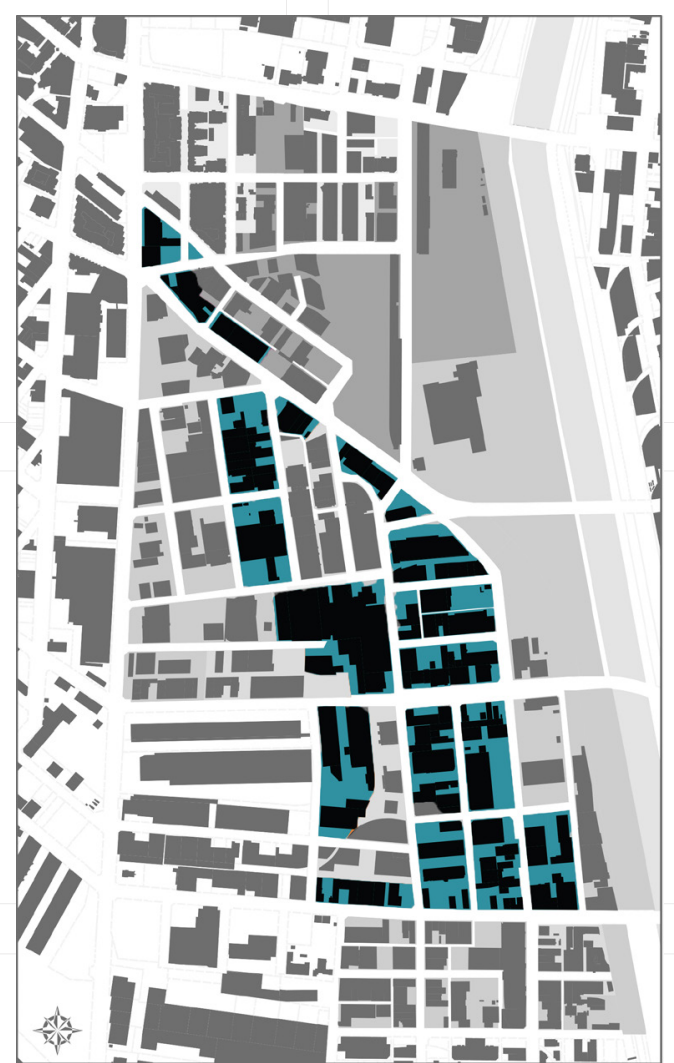

SD-LI

The intent of the SD-Light Industrial Zone is to incubate innovation by providing a development pattern ideal for new businesses and a Cleantech corridor.

The general nature consists of a variety of building types with small footprints to provide space for light industry uses. Due to the small footprint size of the existing industrial building stock, it is also a suitable location for research institutions, green technology facilities, technology and architecture firms, and smaller scale manufacturing uses. This Transect will serve as a buffer from heavier industrial uses. Its location near the civic, transportation, and business center of downtown, and the surrounding academic institutions and neighborhoods, will serve as a catalyst for a new businesses within the Cleantech corridor. 

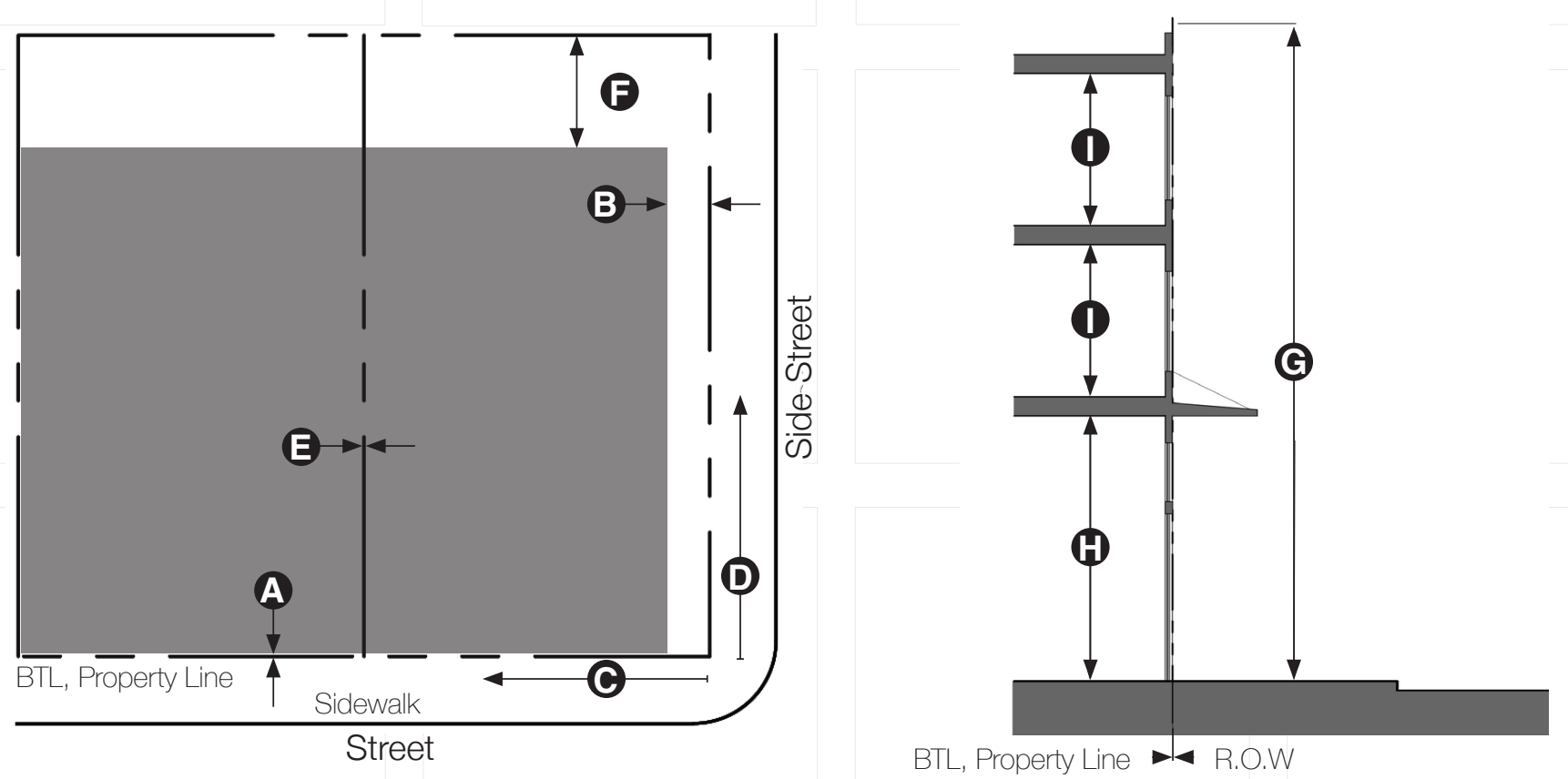

\section{KEY}

- - - Property Line Building Area

\begin{tabular}{|c|c|c|}
\hline \multicolumn{3}{|c|}{ Building Placement } \\
\hline \multicolumn{3}{|c|}{ Build-to Line Distance from Property Line } \\
\hline Front & $0^{\prime}(\mathrm{BTL}=\mathrm{PL})$ & A \\
\hline Side Street & 5 & $\mathbf{B}$ \\
\hline \multicolumn{3}{|c|}{ BTL Defined by a Building } \\
\hline Front & $70 \% \min$. & C \\
\hline Side & $50 \% \min$. & D \\
\hline
\end{tabular}

\begin{tabular}{lcl}
\hline Set Back (Distance from Property Line) & \\
\hline Side & $0^{\prime}$ & $\mathbf{E}$ \\
\hline
\end{tabular}

\begin{tabular}{lll} 
Rear & & \\
\hline Adjacent to T5 Zone & 8 & $\mathbf{G}$ \\
\hline Adjacent to Any Other Zone
\end{tabular}

\begin{tabular}{ll}
\hline \multicolumn{1}{c}{ Adjacent to Any Other Zone } & 5 \\
\hline Building Form & \\
\hline Lot Coverage & $80 \% \mathrm{~min}$. \\
\hline
\end{tabular}

\section{Notes}

All ground-floor entrances must face the Front or Side Street

\section{Use}

Live/Work, Light Industrial, Clean Technology, Light Manufacturing

*See Land Use Table for specific uses.

\section{Height}

Building Min. 20'

Building Max. 4 stories and $45^{\prime}$

Ground Floor Ceiling 14' min.

Upper Floor(s) Ceiling 8' min.

\begin{tabular}{ll}
\hline Notes & $\mathbf{(}$ \\
\hline Within
\end{tabular}

Within 20' of rear Lot Line, buildings may not be more than a story taller than the allowed height of adjacent buildings.

Buildings with Light Industrial uses are not allowed to have Residential uses on upper floors.

All required setbacks adjacent to streets shall be landscaped. 


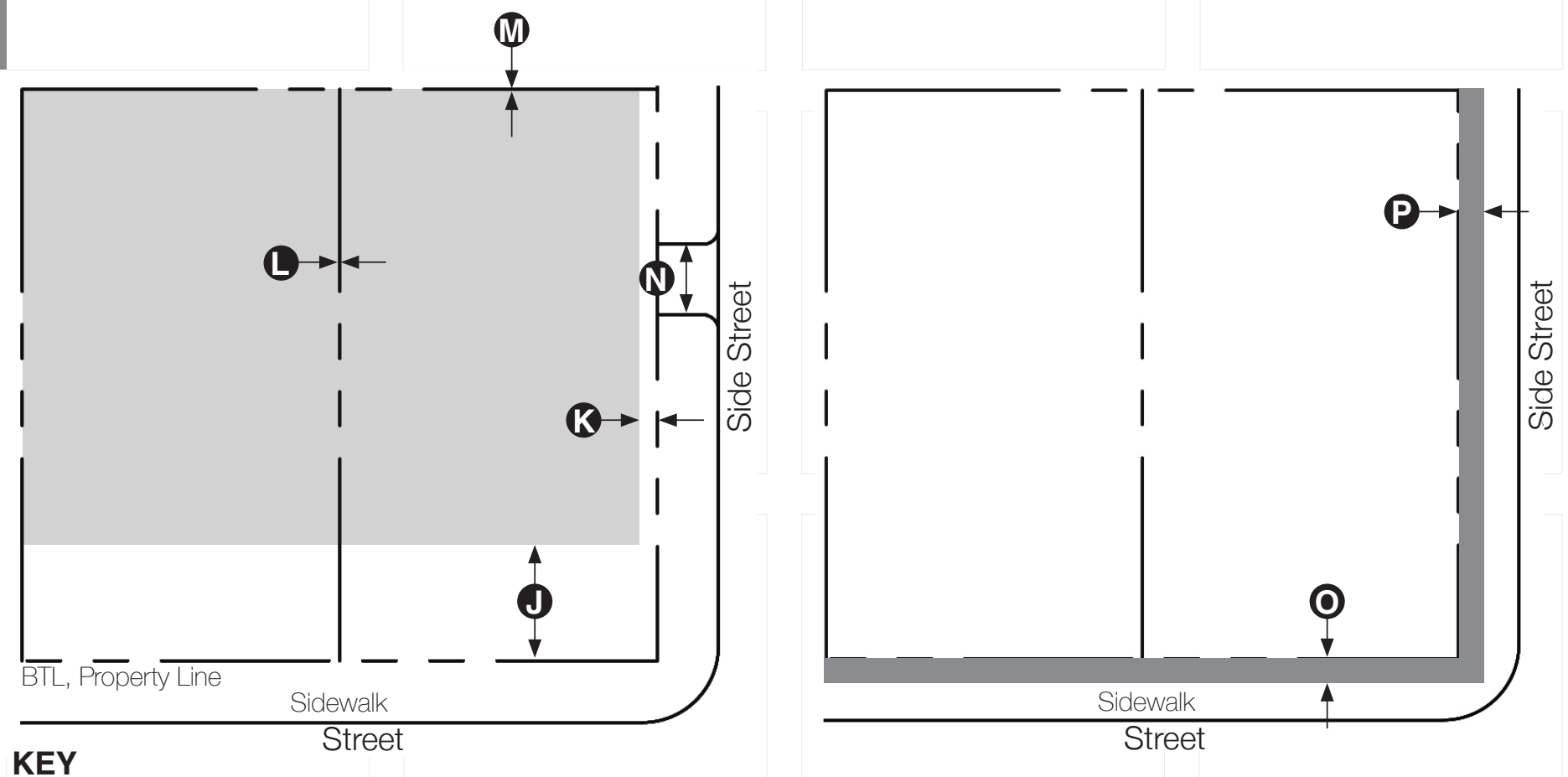

- - - Property Line

Parking Area

\section{Parking}

Location (Distance from Property Line)

\begin{tabular}{lll}
\hline Front Setback & $30^{\prime}$ min. & ( \\
\hline Side Street Setback & $3^{\prime}$ min. & Q \\
\hline Side Setback & 0' min. & D \\
Rear Setback & 0' min. & (U) \\
\hline
\end{tabular}

Curb Cut or Parking Driveway Width

\begin{tabular}{cc}
$\leq 40$ spaces & $14^{\prime} \max$. \\
$>40$ spaces & $18^{\prime} \max$. \\
\hline Required Spaces & \\
\hline
\end{tabular}

\section{Ground Floor}

Uses $\leq 2,000 \mathrm{sf}$

Uses $>2,000 \mathrm{sf}$

\section{Upper Floors}

Live/Work Units

\section{Notes}

A minimum of one bicycle rack place shall be provided per land use.

For Live/work land uses a min. of 0.10 bicycle spaces/bedroom shall be provided.
In addition a minimum of one bicycle rack place shall be provided within the Public or Private Frontage for every ten vehicular parking spaces.

Parking May be provided off site within 1300' or as shared parking.

Parking encouraged to be underground, aboveground parking lots must be wrapped in active uses. No curb cuts on retail streets or primary pedestrian streets.

\begin{tabular}{lll}
\hline Encroachments & & \\
\hline Location & & \\
\hline Front & 7' max. & $\mathbf{O}$ \\
\hline Side Street & 7' max. & $\mathbf{P}$ \\
\hline
\end{tabular}

\section{Notes}

Encroachments shall not impede the public right of way, violate the American Disabilities Act, or cause significant risk or conflict with public safety and vehicular traffic.

See Land Use Table - LI for specific encroachments allowed.

\section{Arts District Form-Based Code}


Table 6. Land Use Light Industrial

\begin{tabular}{l}
\hline Use Type \\
Industry \\
\hline Laboratory, Experimental, Analytical \\
\hline Manufacturing: Light \\
\hline Research and Development \\
Facility \\
\hline Storage \\
\hline Technology Firm \\
\hline Biomedical research/ \\
manufacturing \\
\hline Food Processing and Production \\
\hline Test Kitchen \\
\hline Entertainment-related post- \\
production \\
\hline Furniture and clothing design \\
\hline Technology Firm \\
\hline Media Production \\
\hline Media Production \\
\hline Wholesaling and Distribution \\
\hline Residential \\
\hline Live/work \\
\hline Notes
\end{tabular}

Notes

Retail is only allowed as part of a frontage on ground floor only.

\section{Service}

Bank/Financial Services $\quad<3,500 \mathrm{sf}$

No drive-through services

Automatic Teller Machine

Animal Services

Lodging

Inn, Hotel, Bed \& Breakfast

Office: Professional

\section{General Retail}

Retail frontage in support of Light Manufacturing, Wholesaling and Distribution, or Light Industrial Use

\section{Transportation}

Parking Facility: Public or Private

\section{Encroachments}

Eaves, Awnings, Shop Blinds, and Canopies

Signs, Walls

Street Furniture 

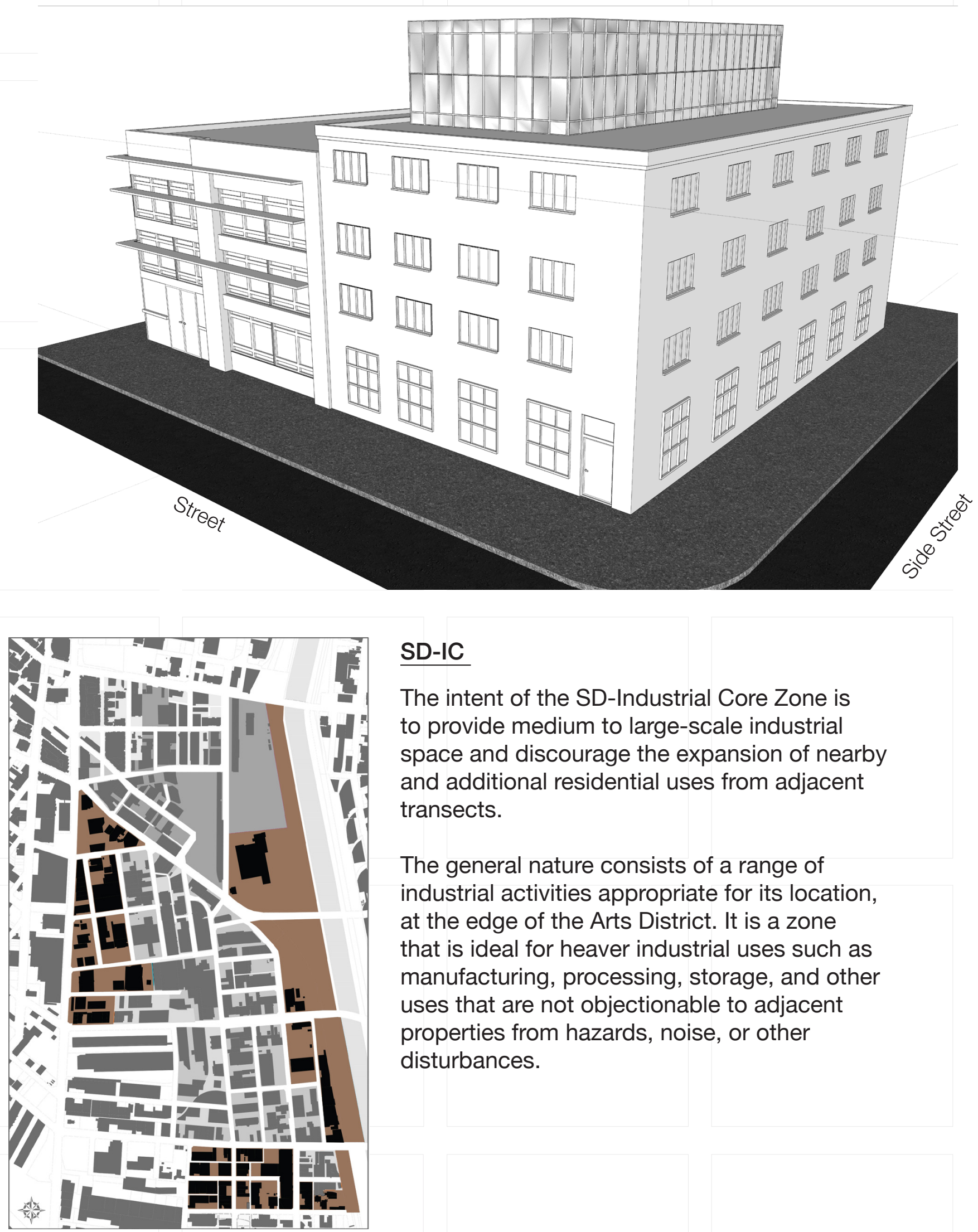

SD-IC

The intent of the SD-Industrial Core Zone is to provide medium to large-scale industrial space and discourage the expansion of nearby and additional residential uses from adjacent transects.

The general nature consists of a range of industrial activities appropriate for its location, at the edge of the Arts District. It is a zone that is ideal for heaver industrial uses such as manufacturing, processing, storage, and other uses that are not objectionable to adjacent properties from hazards, noise, or other disturbances. 

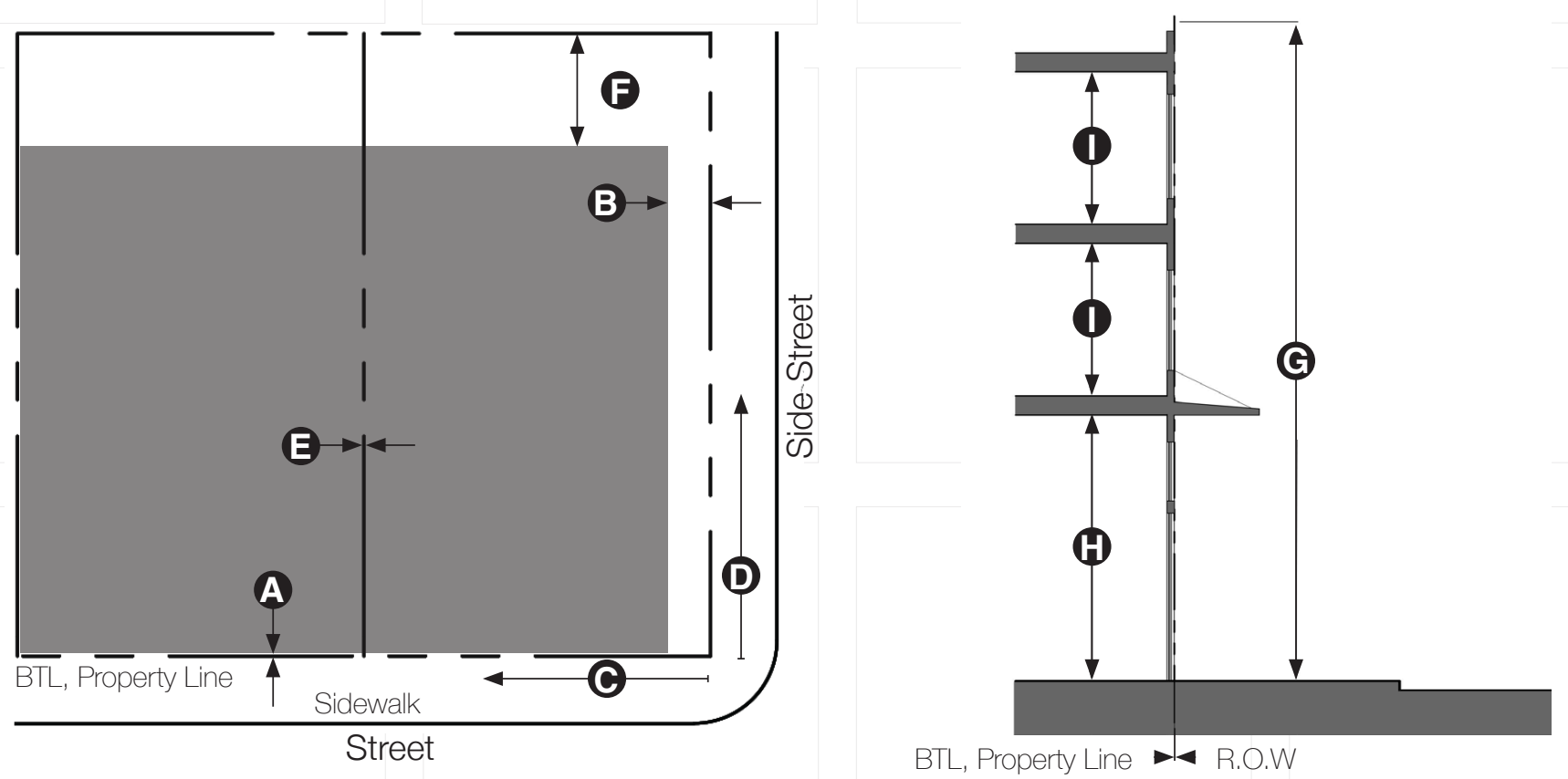

\section{KEY}

- - - - Property Line

Building Area

\begin{tabular}{lll}
\hline \multicolumn{2}{|l}{ Building Placement } & \\
\hline Build-to Line Distance from Property Line & \\
\hline Front & $0^{\prime}(\mathrm{BTL}=\mathrm{PL})$ & $\mathbf{A}$ \\
\hline Side Street & $5^{\prime}$ & B \\
\hline
\end{tabular}

BTL Defined by a Building

Front

$75 \% \min$.

Side

$50 \% \min$.

\begin{tabular}{lcl}
\hline Set Back (Distance from Property Line) & \\
\hline Side & 0 & '
\end{tabular}

\begin{tabular}{lll} 
Rear & & \\
\hline Adjacent to T5 Zone & 8' & $\mathbf{E}$ \\
\hline
\end{tabular}

Adjacent to Any Other Zone $5^{\prime}$

\begin{tabular}{ll}
\hline Building Form & \\
\hline Lot Coverage & $80 \% \mathrm{~min}$. \\
\hline
\end{tabular}

Notes

All ground-floor entrances must face the Front or Side Street

\section{Use}

Live/Work, Light Industrial, Clean Technology, Light Manufacturing

*See Land Use Table for specific uses.

\begin{tabular}{ll}
\hline Height & \\
\hline Building Min. & $22^{\prime}$ \\
Building Max. & 4 stories \\
& and 45' \\
\hline
\end{tabular}

Ground Floor Ceiling 14' min. G

Upper Floor(s) Ceiling 8' min.

Notes $\quad \mathbf{\theta}$

Within 20 ' of rear Lot Line, buildings may not be more than a story taller than the allowed height of adjacent buildings.

Buildings with Light Industrial uses are not allowed to have Residential uses on upper floors.

All required setbacks adjacent to streets shall be landscaped. 


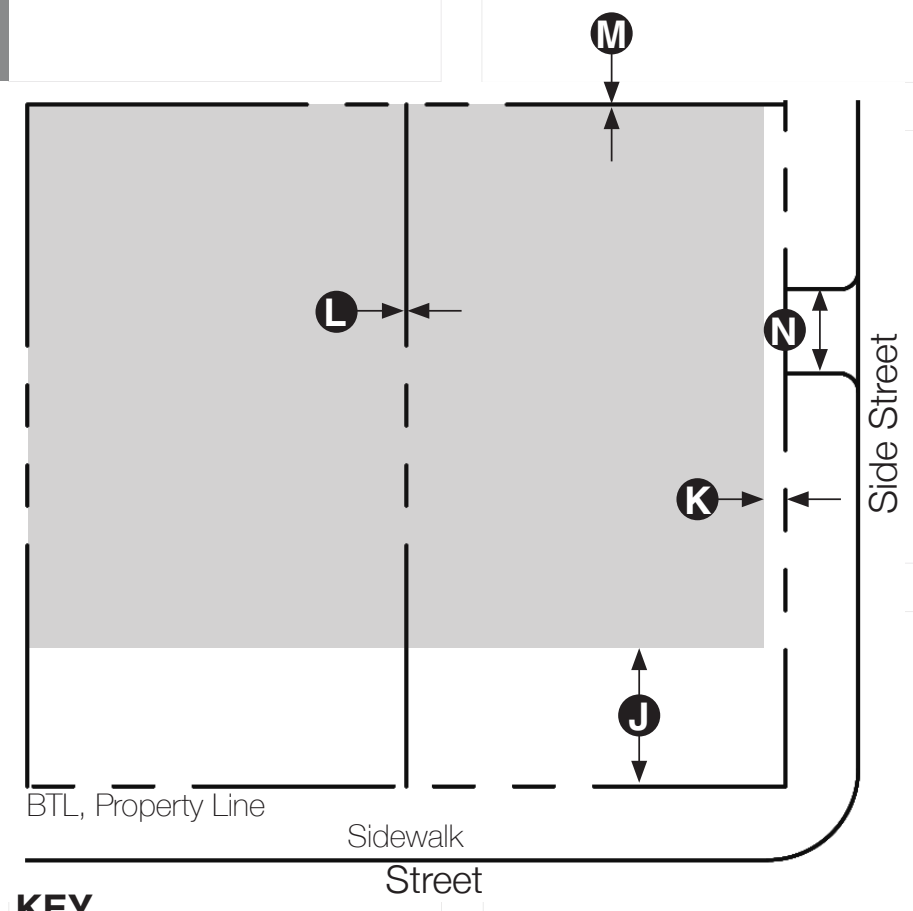

KEY

Parking Area

\section{Parking}

Location (Distance from Property Line)

\begin{tabular}{lll}
\hline Front Setback & 30' min. & ( \\
\hline Side Street Setback & 3' min. & ( \\
\hline Side Setback & 0' min. & (D) \\
Rear Setback & 0' min. & (U) \\
\hline
\end{tabular}

Curb Cut or Parking Driveway Width

$\begin{array}{cc}\leq 40 \text { spaces } & 14^{\prime} \text { max. } \\ >40 \text { spaces } & 18^{\prime} \text { max. }\end{array}$

\section{Ground Floor}

Uses $\leq 2,000 \mathrm{sf}$

Uses > 2,000 sf

\section{Upper Floors}

Residential

Live/Work Units

\section{Notes}

A minimum of one bicycle rack place shall be provided per land use.

For Live/work land uses a min. of 0.10 bicycle spaces/bedroom shall be provided.

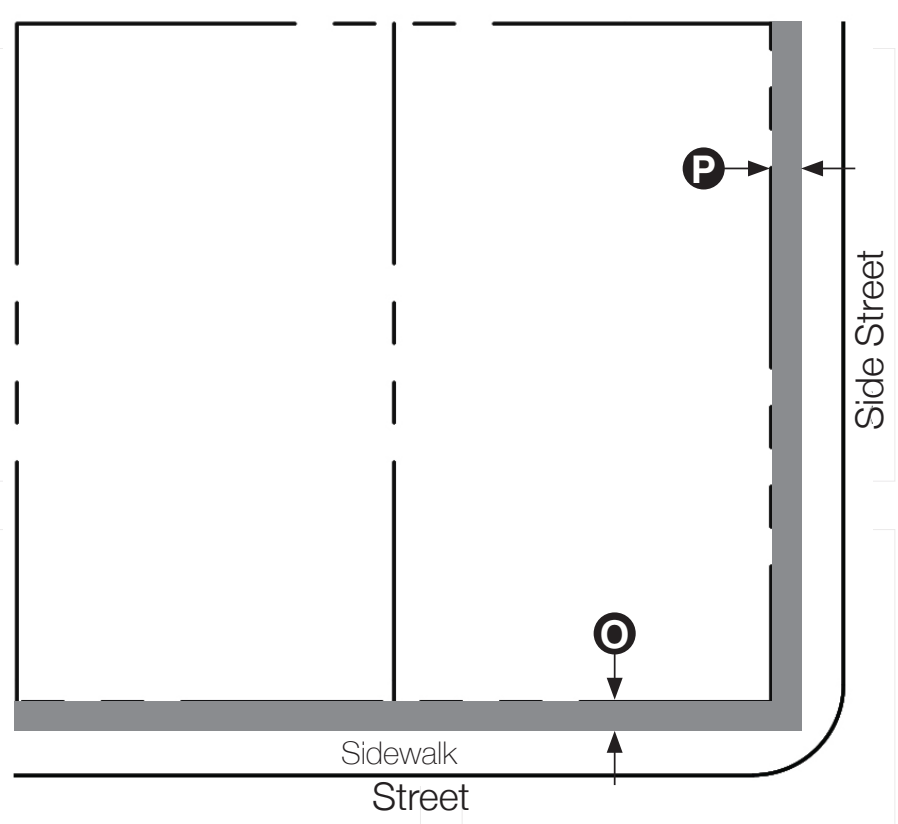

In addition a minimum of one bicycle rack place shall be provided within the Public or Private Frontage for every ten vehicular parking spaces.

Parking May be provided off site within 1300' or as shared parking.

Parking encouraged to be underground, aboveground parking lots must be wrapped in active uses. No curb cuts on retail streets or primary pedestrian streets.

\begin{tabular}{lll}
\hline Encroachments & & \\
\hline Location & & \\
\hline Front & 7' max. & $\mathbf{O}$ \\
\hline Side Street & 7' max. & $\mathbf{P}$ \\
\hline
\end{tabular}

\section{Notes}

Encroachments shall not impede the public right of way, violate the American Disabilities Act, or cause significant risk or conflict with public safety and vehicular traffic.

See Land Use Table - IC for specific encroachments allowed.

\section{Arts District Form-Based Code}


Table 7. Land Use Industrial Core

\begin{tabular}{l}
\hline Use Type \\
\hline Industry \\
\hline Laboratory, Experimental, Analytical \\
\hline Manufacturing: apparel, technology, smaller-scale \\
fabrication, etc. \\
\hline Heavy Industrial \\
\hline Recycling Facility \\
\hline Research and Development Facility \\
\hline Storage \\
\hline Transit maintenance and operation \\
\hline Materials collection and recycling \\
\hline Food processing and distribution \\
\hline Biomedical research/manufacturing \\
\hline Entertainment-related post-production \\
\hline Furniture and clothing design \\
\hline Technology Firm \\
\hline Media Production \\
\hline Wholesaling, Warehouse and Distribution \\
\hline
\end{tabular}

\section{Service}

Office: Professional

Transportation

Parking Facility: Public or Private

Encroachments

Eaves, Awnings, Shop Blinds, and Canopies

Signs, Walls

\section{Notes}

All Light Industrial Uses are allowed in the Industrial Core Zone 
Arts District Form-Based Code 
chapter 4

\section{Public Space Standards and Design Guidelines}

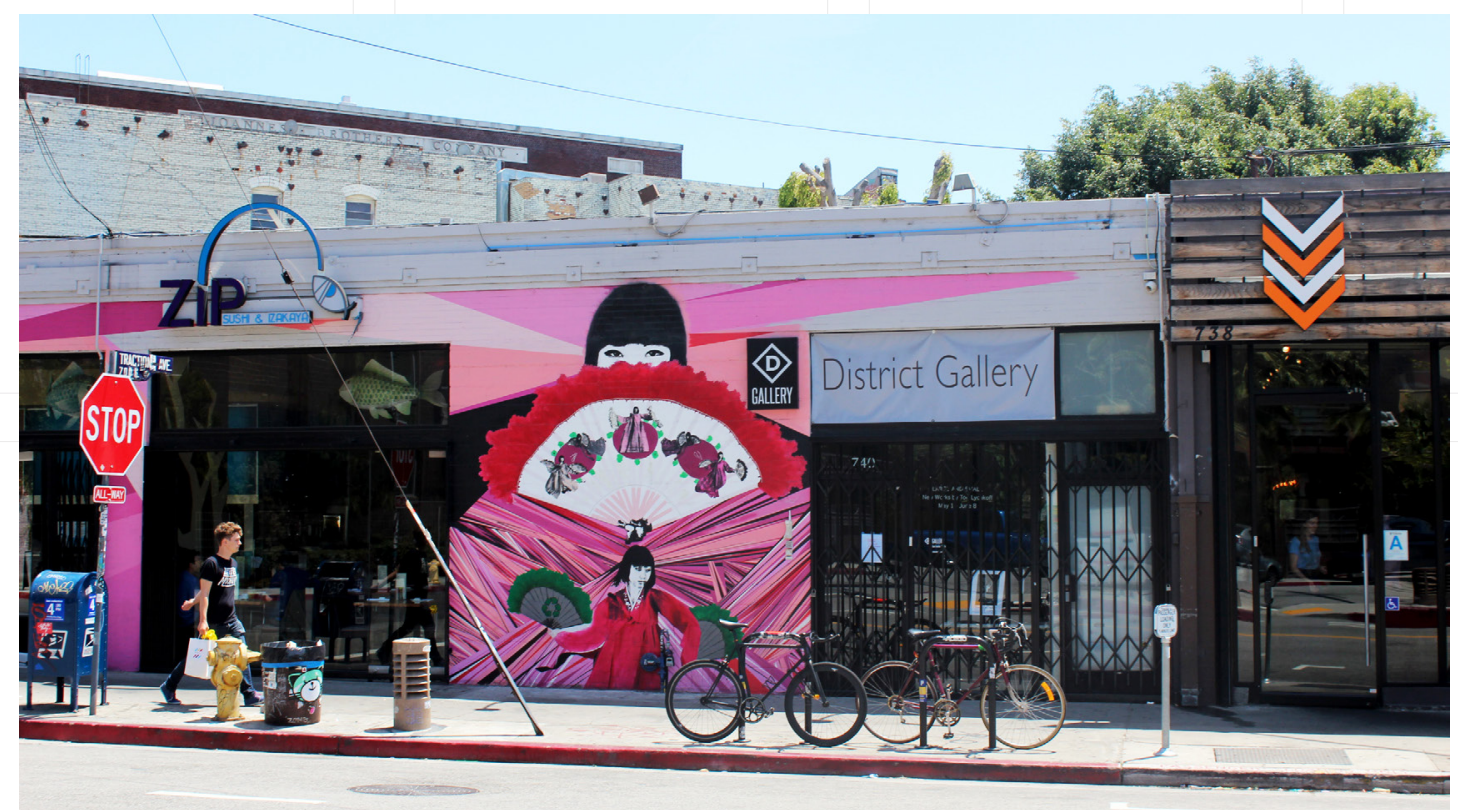

Left: A mural painted on the facade of Zip Sushi Izakaya along Thrid Street in the Arts District.

\section{Introduction}

The Arts District circulation network will be designed to allow for multimodal transportation options that are integrated with adjacent land uses. A well-designed street network will help to promote a healthy and vibrant neighborhood. The proposed system of streets will emphasize an active lifestyle through pedestrian and bicycle improvements as well as significant greenways and landscaping. Design guidelines and conceptual diagrams have been prepared for the public space and streets within the Arts District. 


\section{General Public Space Design Characteristics}

\section{Sidewalks}

Sidewalks should provide an interconnected network for pedestrian access and other elements that include street furniture, lighting, planters, and trees. Street furniture will be placed in a consistent, well-defined zone parallel to the pedestrian walking zone. Sidewalks and medians will employ low impact development standards and establish a tree canopy.

Right: 12th Avenue Green Street in Portland. Left: Outdoor seating at Novel Cafe on Traction Avenue.
Right: Pie Hole and Poketo frontages are transparent and invite pedestrian traffic.
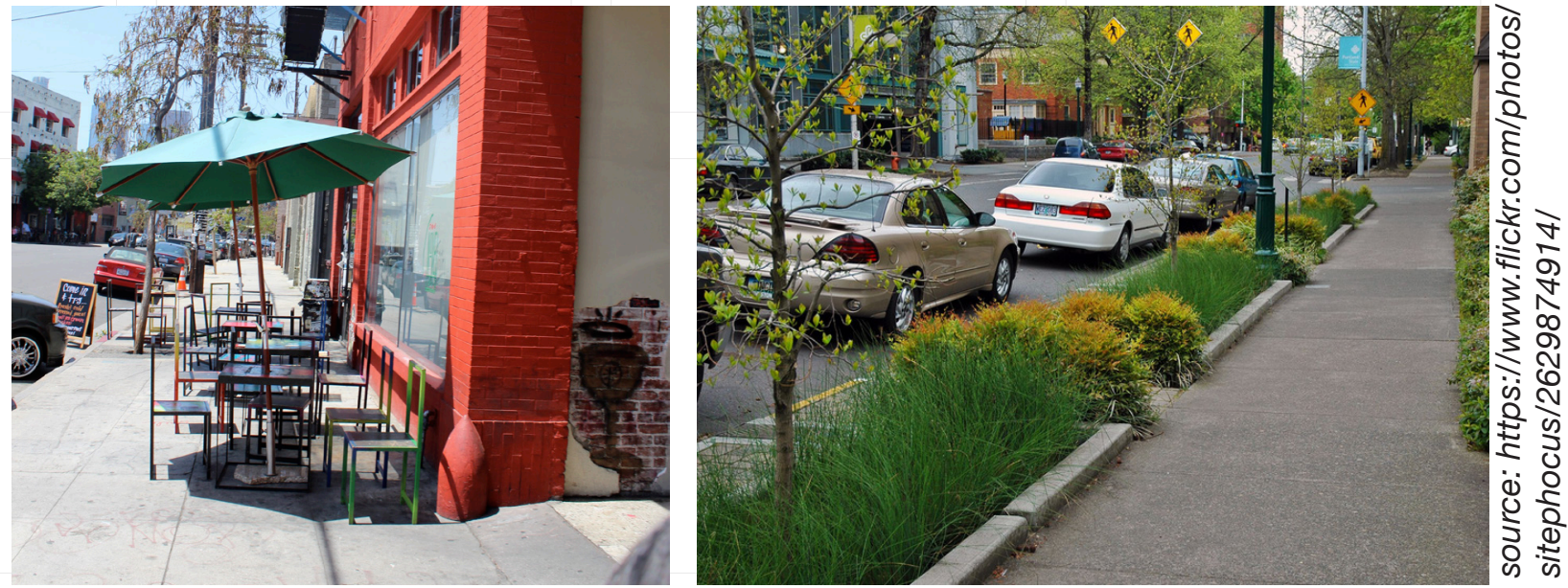

\section{Frontage Design}

Building frontages in the Arts District should maintain a common industrial urban character. General Retail storefronts should be transparent and invite pedestrian traffic from the street. Building facades should reflect design features consistent with existing historical and industrial architecture typologies. Restaurants and cafes are encouraged to provide outside seating to a maximum of five feet, as long a they do not impede the public right of way, violate the American Disabilities Act, or cause significant risk or conflict with public safety and vehicular traffic.
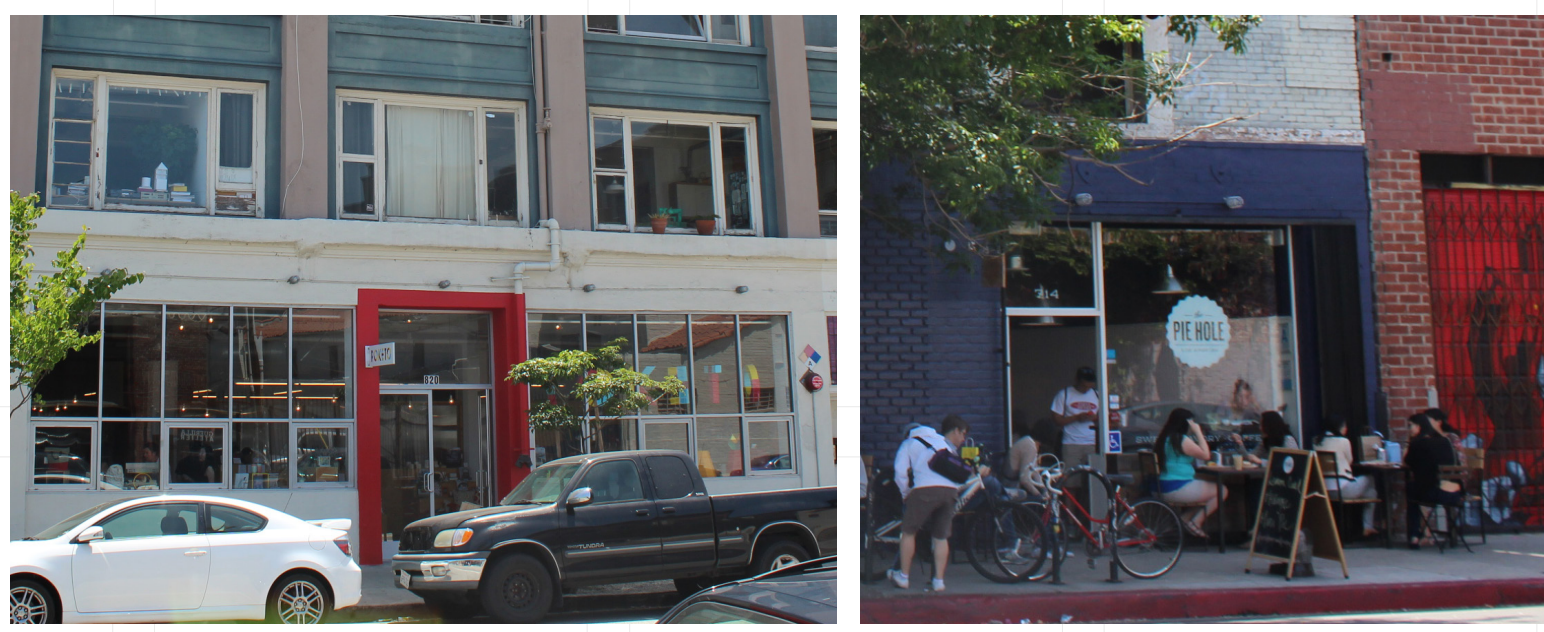


\section{Building Size and Massing}

Buildings are to follow the Regulating Plan for height and massing for the applicable transect zone. New buildings should be taller, with smaller footprints to maximize density and encourage the development of a pedestrian oriented urban environment. New buildings are to be built to property line in order to maintain continuity with the existing development pattern.

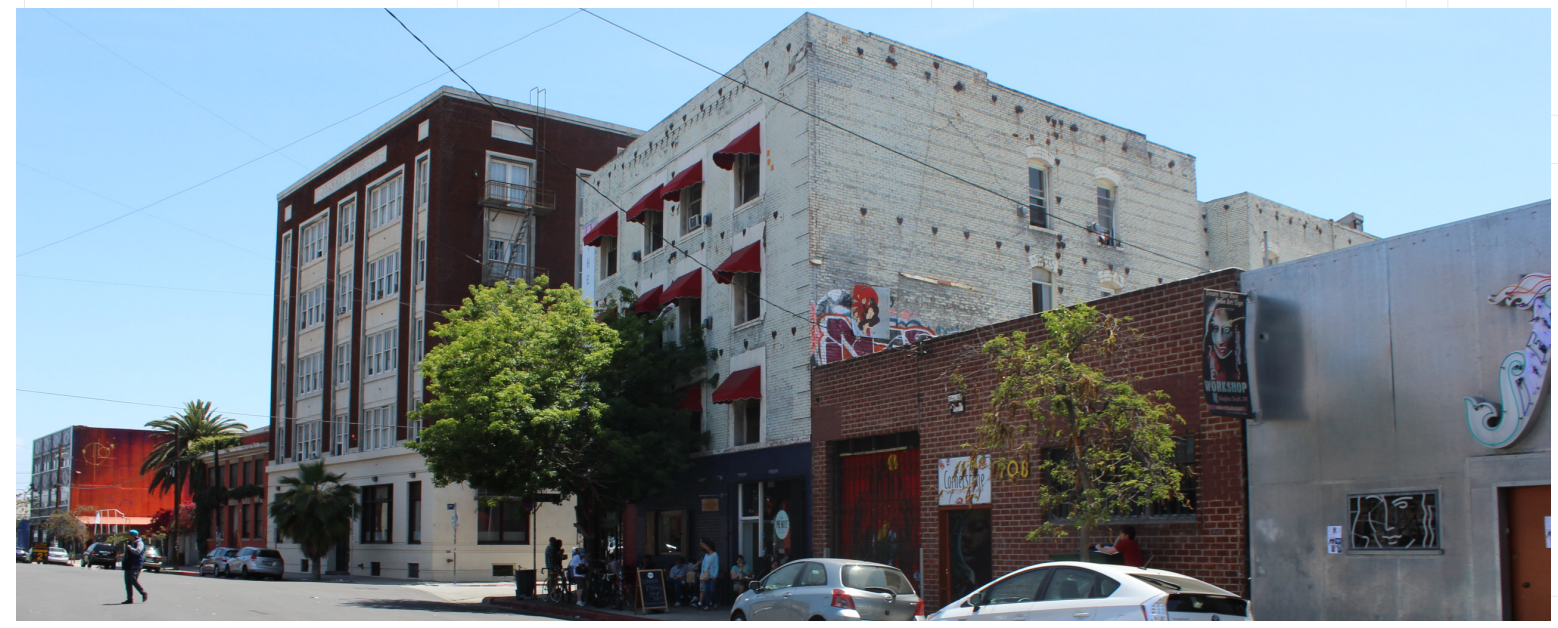

Left: Existing massing on Traction Avenue.

\section{Parking Design}

Lots used only for parking will contain trees, planters, or other forms of landscaping. Parking garages must be surrounded by active uses at street level. Parking garages shall be designed to mirror existing building form and façades of the neighborhood. Landscaping and planters are encouraged for open parking lots.
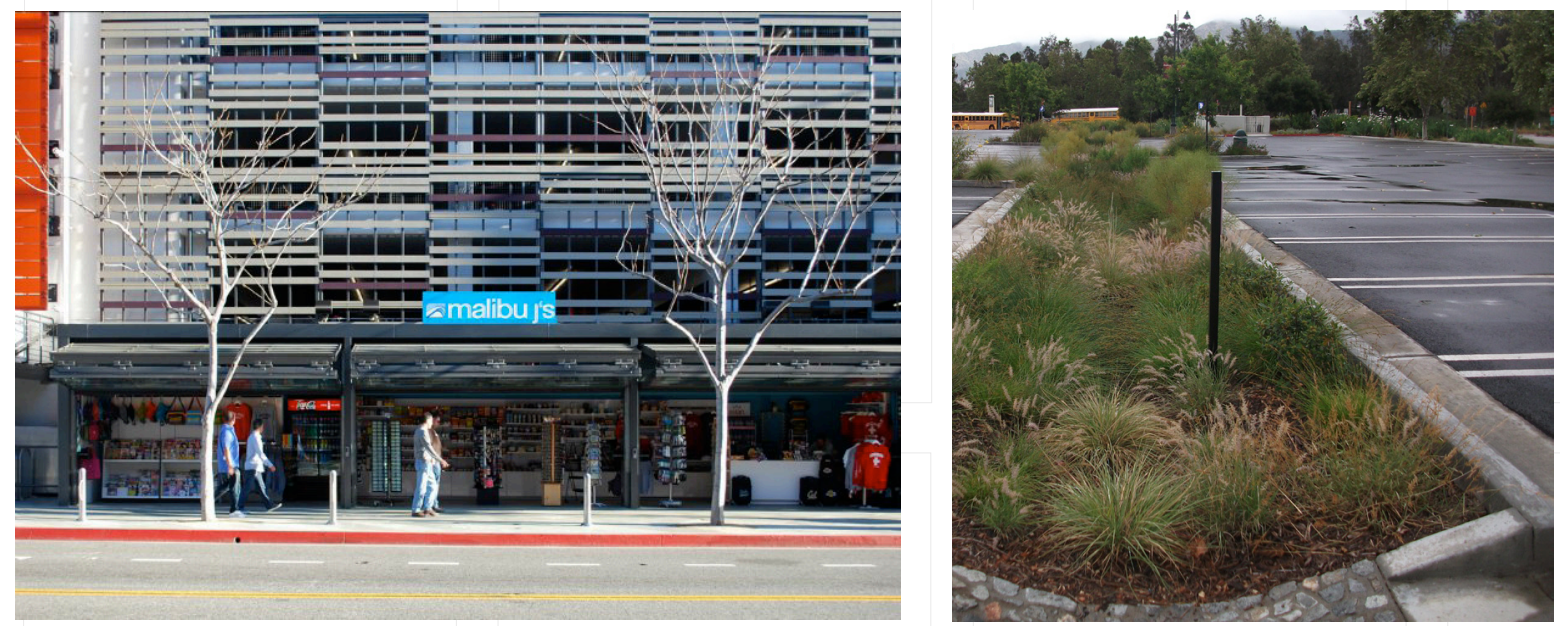

Left: Parking garage in Santa Monica with retail use on the ground floor. Right: $L A$ Zoo parking lot landscaped with bioswale. 


\section{Public Art}

The Arts District is a hub of arts and culture, its identity is displayed on almost every building façade, wall, sidewalk, and architectural design in the area. To maintain the Arts Districts unique identity as a place of urban culture, public art should be conserved and incorporated into the design of existing, new, or reuse projects. Public Art should be displayed prominently on any side of a building, but is encouraged to be in the most publicly visible area.

Right: Public art is an essential component to unique to the Arts District community.
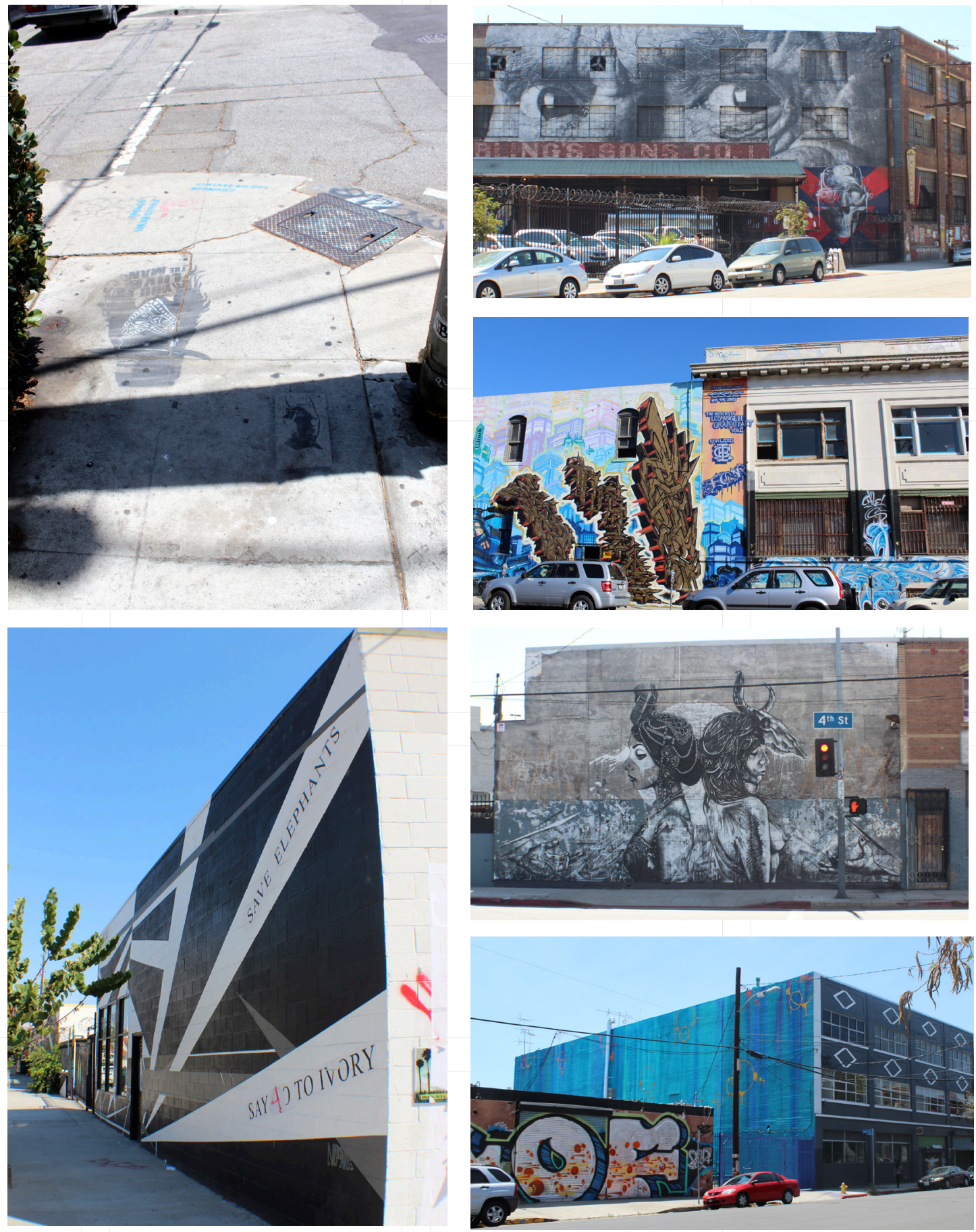


\section{Bicycle Parking Design}

Bicycle parking requirements will follow the Regulating Plan for each transect. Bicycle rack designs are encouraged to be artistic or themed. Short-term bicycle parking should consist of racks that are located outside of the building, on public sidewalks, or on parklets. Racks should be designed to support the bicycle upright on a horizontal plane by its frame in two places. Bicycle corrals can be used to offer on-street parking in replacement of a single car parking space with an allotment of 8-12 bicycle parking spaces. Long-term bicycle parking should contain a high degree of security in the form of a locker, bike room, bike cage, or bike station.
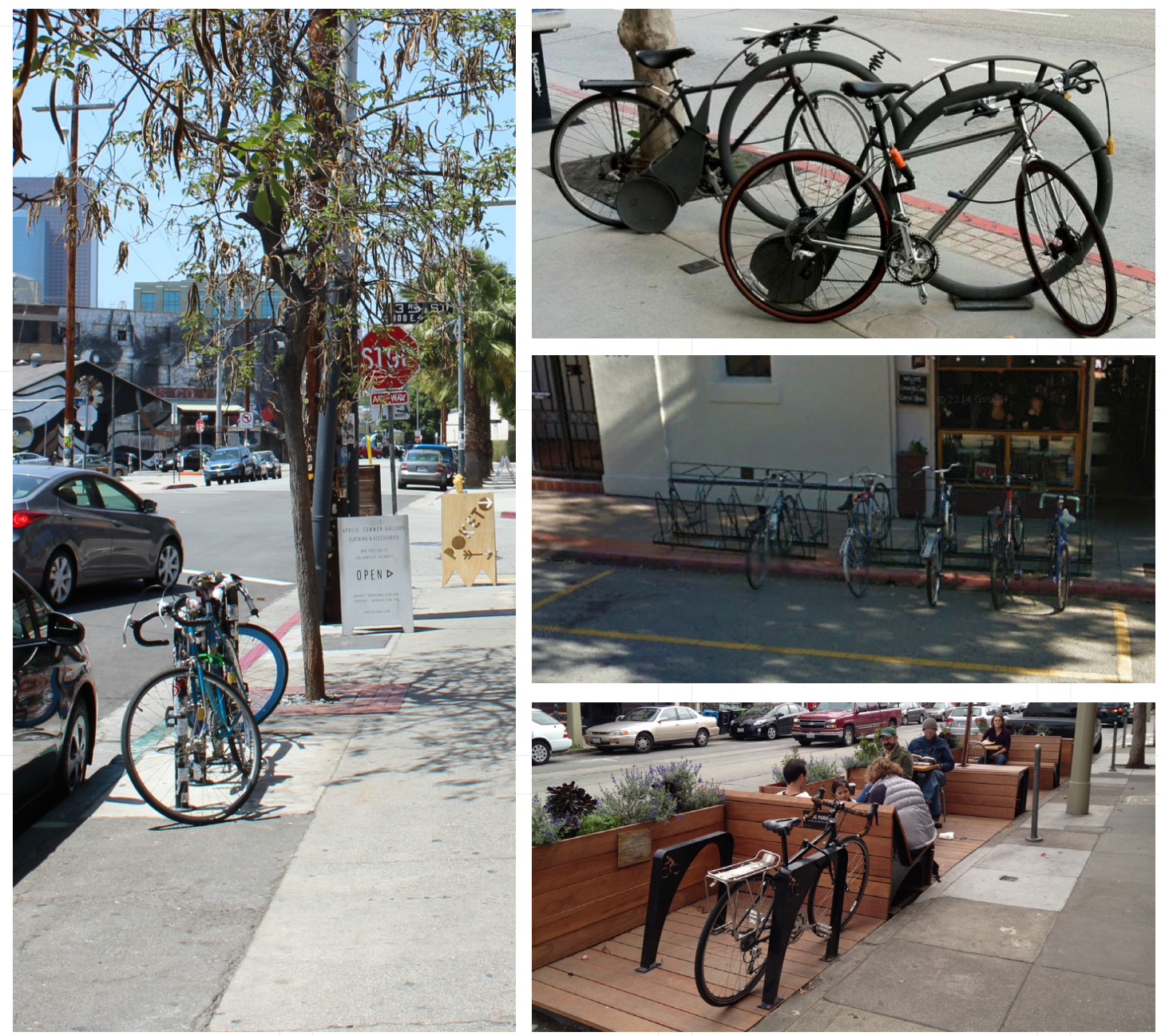

Left: Existing bicycle rack on Traction Avenue. Right: Example of themed bike rack, on street bike parking, and parklet bike racks.
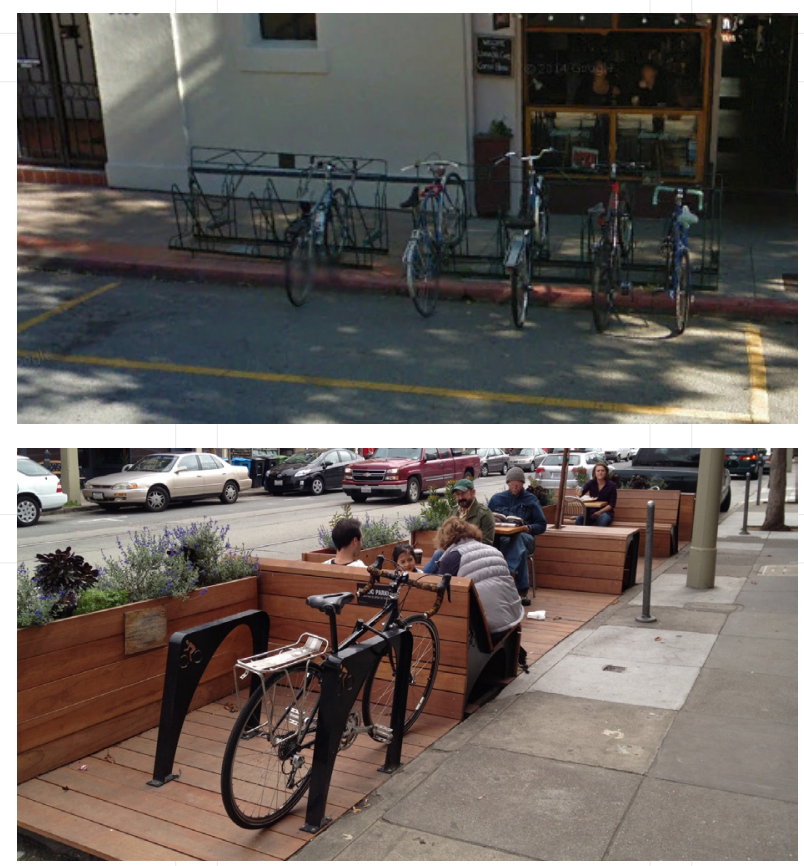

\section{Landscaping}

Landscaping should follow the open and green space strategies outlined below. Planters should be incorporated into the sidewalk to provide storm water treatment through planted vegetation. Planters and landscaping will create a buffer between pedestrians and the street as a means to protect public safety and enhance the aesthetics of a thoroughfare. 


\section{Open and Green Space}

The industrial urban environment of the Arts District has a significant lack of green or open space. However, there are opportunities in unconventional locations such as vacant underused parcels, large flat industrial roofs, Los Angeles' historical bridges, and existing parking spaces. In conjunction to the Sixth Street Viaduct and LA River Master Plan, the Arts District will establish linkages to connect with future networks of open space. The proximity to the LA River provides an opportunity to design open space and landscaping features to protect water quality and water supply through a variety of low impact development strategies. The following are strategies that can be directly applied to the Arts District as a means to create green and open space.

\section{Green Streets}

Arts District residents have cited their desire to develop a river walk. Green streets are an effective tool to reduce pollution from storm water runoff, create aesthetically pleasing streets, and provide much needed green space. Green streets have landscape features that filter, capture, and infiltrate storm water runoff through natural systems. Additionally, green streets provide a buffer zone between pedestrians and automobile traffic.

\section{Pervious Pavement}

Pervious pavement systems allow rainfall to penetrate through paved surfaces into the ground or a storage container to manage storm water runoff by providing retention. Pervious pavement systems can also be used to vary street surfaces and promote low-traffic speeds or identify crosswalks. Pervious paving systems can be applied to parking lots, alleys, trail systems, roadways, and sidewalks.

Left: Permeable pavement. Right: Permeable sidewalk in Minneapolis.
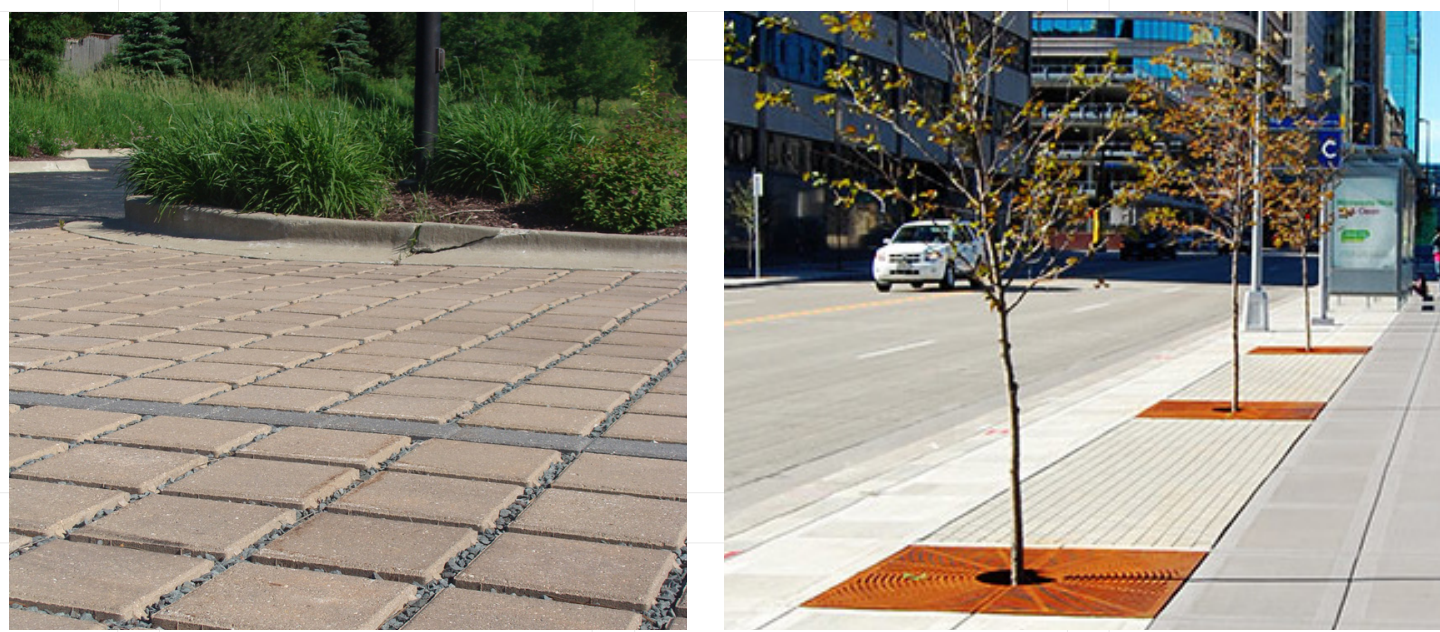

left, source: center for neighborhood technology right, source: http://www.avrconcrete.com/pic/proj/Marquette200.jpg 


\section{Green Roofs}

In the Arts District, green space is rare but large industrial buildings with flat roofs are common. These roofs can be fitted with green roof systems that are an extension of the existing roof. Green roofs are water-proof, retrofitted with a drainage system, and contain green space with lightweight growing plants. Green roofs have multiple benefits that include aesthetic improvements, storm water management, energy efficiency, reduced urban heat island effect, local job creation, improved air quality, recreational, community, and commercial space.
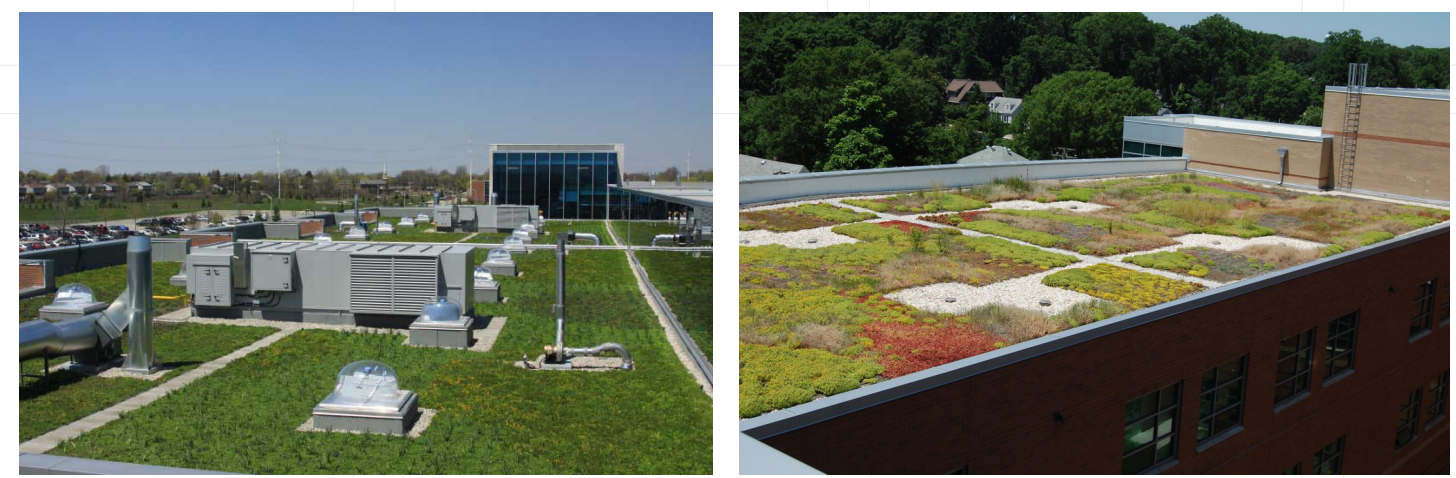

Left: Green roofs on top of industrial buildings.

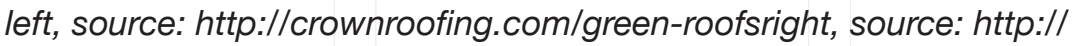
right, source: http://www.2championroofing.com/category/green-roof/

\section{Green Walls}

Similar to green roofs, green walls can improve energy efficiency and air quality, reduce the urban heat island effect, and create local jobs. In an industrial urban environment, green walls can provide noise reduction and provide space for urban agriculture. With a proximity to skid row, programs can be implemented to help rehabilitate the homeless and bring the community closer together by providing jobs in urban agriculture.
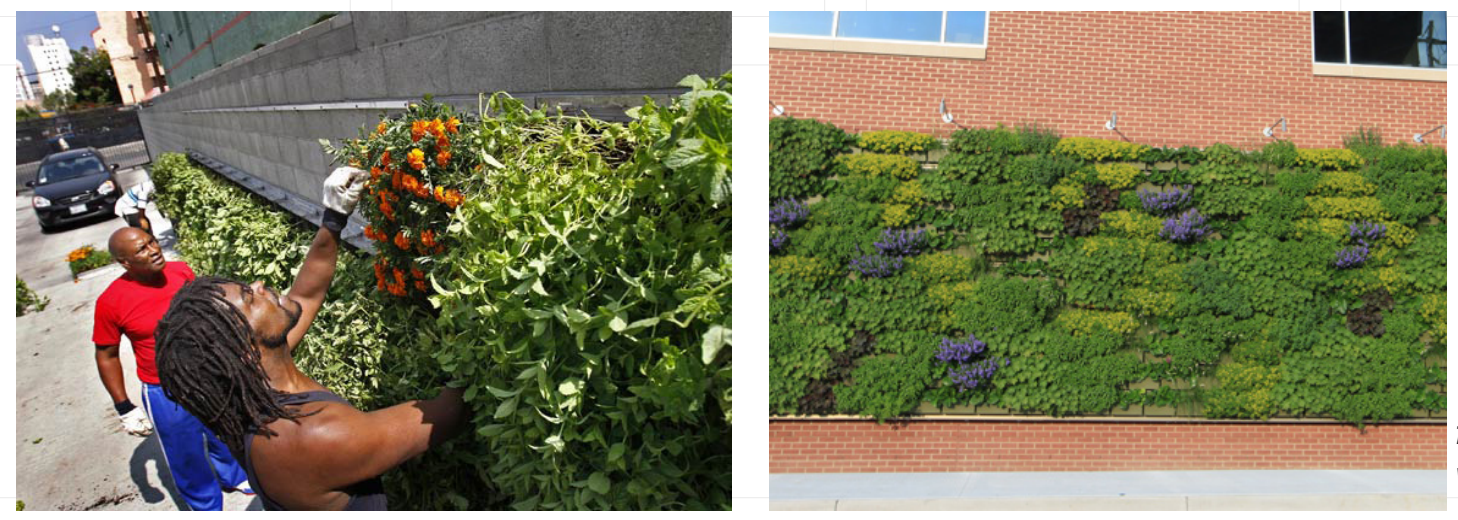

Left: Vertical urban farm. Right: Green wall.

left, source: http://crownroofing.com/green-roofsright, source: http:// right, source: http://www.2championroofing.com/category/green-roof/ 


\section{Storm water Curb Extensions}

Strom water curb extensions are landscaped space within the parking zone of a street that is used to capture runoff. They can be designed as vegetated swales, planters, and rain gardens. Because they are an extension of the curb they can be used as a traffic calming measure that increases pedestrian safety while adding significant green space to an urban area.

\section{Planter Boxes (bio filtration)}

Planter boxes provide landscaped space on a sidewalk that also treats storm water runoff.

\section{Civic Space}

\section{Parklets}

Parklets are an economically viable solution for needed open and green space along commercial corridors in the Arts District . A parklet is a repurposed part of the street that has been turned into public space for people to enjoy. Parklets provide space for anchor and destination points, encourage pedestrian activity, and foster neighborhood interaction. Parklets can be used to provide additional space for street furniture, landscaping, and bicycle parking. Parklets also benefit business vitality through increased pedestrian attraction and street beautification. Parklets should be located along Traction Avenue and Third Street in order to establish this area as a focal point for the neighborhood.

\section{Pocket Parks}

Pocket Parks are small-scale open and green space created on vacant lots or small irregular pieces of land. Similar to parklets, pocket parks help to regenerate an area and provide space for the community to play, meet, or enjoy.

Right: Parklets

in San Francisco provide unconventional open space in urban areas.
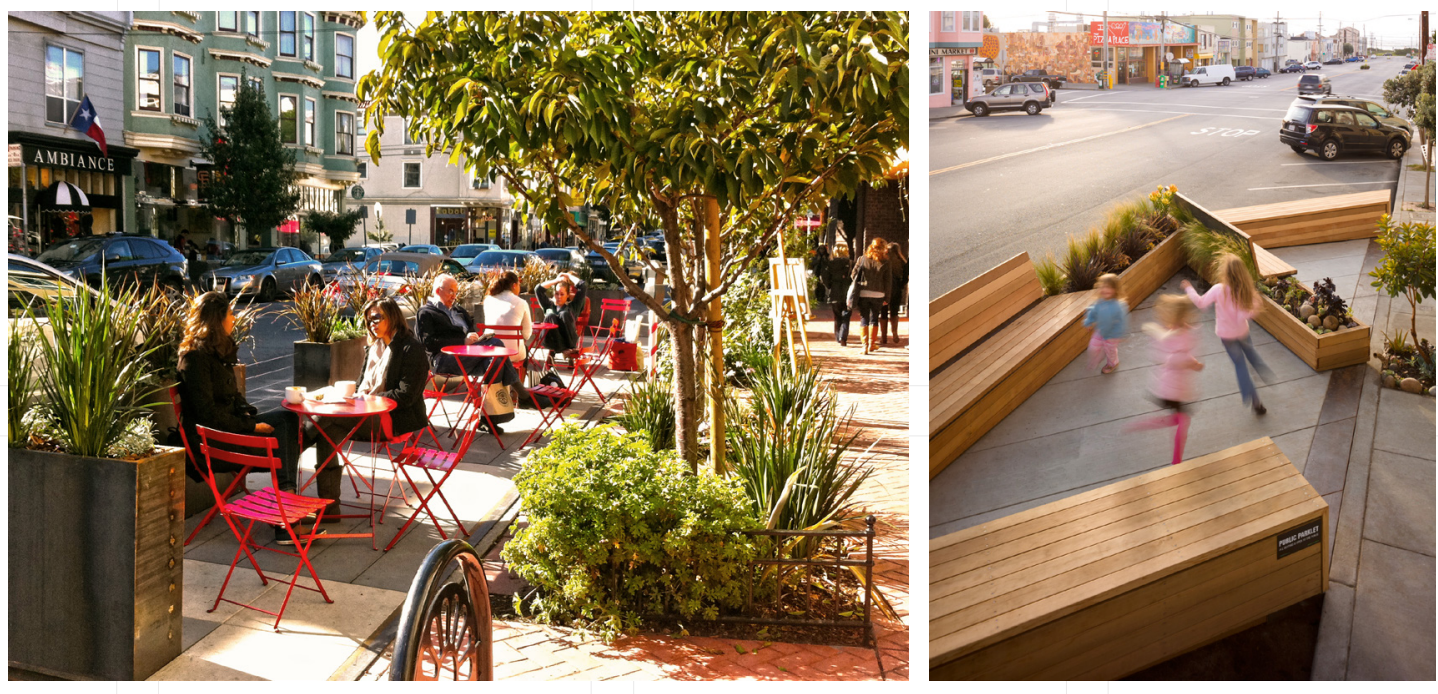


\section{Street Concepts}

The Arts District should create a central hub and linkage to the rest of the neighborhood through enhanced thoroughfare design in the area around Traction Avenue, Third Street, and S. Santa Fe Avenue. This central linkage will boost connectivity to other areas of the Arts District through an improved pedestrian and bicycle path system that includes a green street network with connections to the river, open space, and the Sixth Street Viaduct project. Thoroughfare improvements will focus on pedestrian comfort and safety while accommodating parking, through traffic, and storm water management.

Due to the variability in thoroughfare width streetscape designs and concepts, the following estimates require further calibration. 


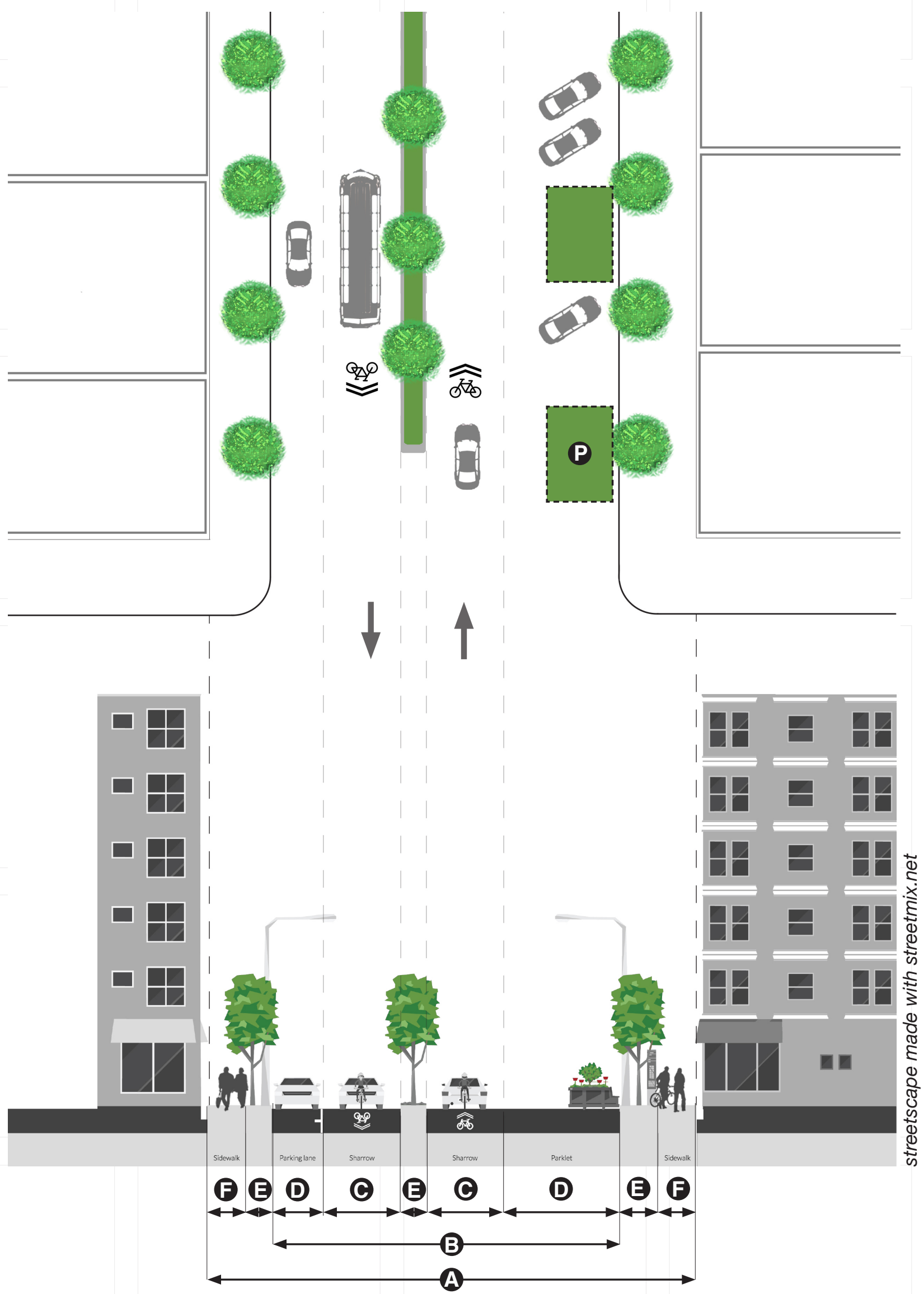


Concepts for Specific Streets - Traction Avenue

\begin{tabular}{|c|c|}
\hline Application & \\
\hline Movement Type & Slow \\
\hline Design Speed & $25 \mathrm{mph}$ \\
\hline Pedestrian Crossing Time & 11.4 seconds \\
\hline Transect Zone & T5 \\
\hline \multicolumn{2}{|l|}{ Overall Widths } \\
\hline Right-of-Way (ROW) Width & $70^{\prime}$ \\
\hline Curb Face to Curb Face Width & $54^{\prime}$ \\
\hline \multicolumn{2}{|l|}{ Lanes } \\
\hline Traffic Lanes & $12^{\prime} \quad \mathbf{C}$ \\
\hline Parking Lanes & $\begin{array}{l}8^{\prime} \text { parallel and 18' } \\
\text { nngled }^{1}\end{array}$ \\
\hline Bicycle Lanes & Sharrowed $\mathbf{C}$ \\
\hline
\end{tabular}

\begin{tabular}{|c|c|}
\hline Medians & $\begin{array}{l}\text { 4'Trees and } \mathbf{E} \\
\text { landscaped }\end{array}$ \\
\hline \multicolumn{2}{|l|}{ Edges } \\
\hline Curb Type & Square \\
\hline Planter Type & $\begin{array}{l}4^{\prime} \text { continuous } \mathbf{\Xi} \\
\text { with breaks for } \\
\text { parking access } \\
\text { and tree wells* }\end{array}$ \\
\hline Landscape Type & $\begin{array}{l}\text { Trees spaced at } \\
30^{\prime} \text { o.c. average }{ }^{*}\end{array}$ \\
\hline Walkway Type & 7' Sidewalk $\boldsymbol{\Theta}$ \\
\hline \multicolumn{2}{|l|}{ Notes } \\
\hline \multicolumn{2}{|c|}{$\begin{array}{l}\text { *All medians, planters, and landscapes should } \\
\text { follow Low Impact Development Standards. }\end{array}$} \\
\hline \multicolumn{2}{|c|}{$\begin{array}{l}\text { 1Parklets are encouraged as a form of open } \\
\text { space adjacent to active commercial uses such as } \\
\text { cafes or restaurants. }\end{array}$} \\
\hline
\end{tabular}

\section{Traction Avenue}

Traction Avenue will be designed to accommodate an urban street characterized by slow moving traffic, sharrowed bike lanes, and high density mixed-use. Landscaping on the sidewalk and median will redefine the thoroughfare to host a canopy of trees and plant life to implement low impact development strategies. Sidewalks will house street furniture, landscaping, and bicycle parking. The street will accommodate a variety of parking options that include angled, parallel, and bicycle parking. Local artists can also design the bicycle racks. Parklets along the northern side of Traction Avenue will provide open space while reinvigorating the pedestrian atmosphere. Wayfinding will be located near SCl-Arc to help people navigate through the Arts District. Wayfinding should also help to brand the Arts District as a unique place of creativity and innovation; it will highlight local art, historical architecture, and popular establishments. 


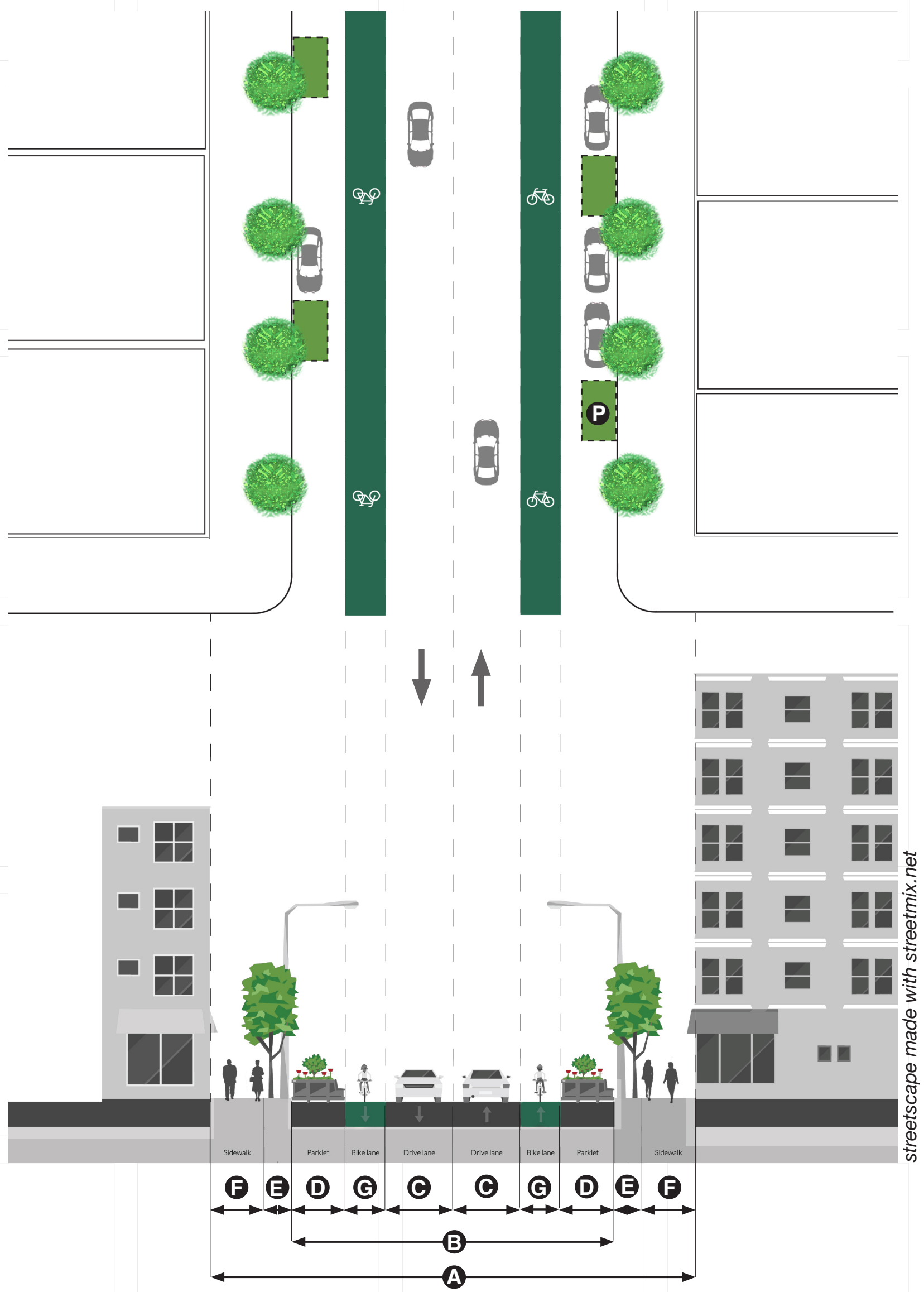




\begin{tabular}{lll}
\hline Application & & \\
\hline Movement Type & Slow & \\
\hline Design Speed & $25 \mathrm{mph}$ & \\
\hline Pedestrian Crossing Time & 9.8 seconds & \\
Transect Zone & T5 & \\
\hline Overall Widths & & \\
\hline Right-of-Way (ROW) Width & $72^{\prime}$ & $\mathbf{A}$ \\
\hline Curb Face to Curb Face Width & $48^{\prime}$ & $\mathbf{B}$ \\
\hline Lanes & & \\
\hline Traffic Lanes & $10^{\prime}$ & $\mathbf{C}$ \\
\hline Parking Lanes & 8' parallel $^{1}$ & D \\
\hline Bicycle Lanes & 6' painted & G \\
\hline
\end{tabular}

\begin{tabular}{ll}
\hline Medians & none \\
\hline Edges & Square \\
\hline Curb Type & $\begin{array}{l}\text { 4' continuous } \\
\text { with breaks for } \\
\text { parking access } \\
\text { and tree wells }\end{array}$ \\
\hline Planter Type & $\begin{array}{l}\text { Trees spaced at } \\
\text { 30' o.c. average* }\end{array}$ \\
\hline Landscape Type & 8' Sidewalk $\mathbf{E}$ \\
\hline Walkway Type & \\
\hline Notes & \\
\hline *All medians, planters, and landscapes should \\
follow Low Impact Development Standards \\
'Parklets are encouraged as a form of open \\
space adjacent to active commercial uses such as \\
cafes or restaurants.
\end{tabular}

\section{Third Street}

The section of Third Street between E. Fourth Place and S. Santa Fe Avenue will be designed as a continuation of Traction Avenue's urban character. Third Street will accommodate slow moving traffic, painted bike lanes, and high density mixed-use. Landscaping on the sidewalk will redefine the thoroughfare to host a canopy of trees and plant life to implement low impact development strategies. Sidewalks will house street furniture, landscaping, and bicycle parking. The street will provide parallel and bicycle parking. Parklets along both sides of Third Street are to be located near active commercial uses to provide open space and have the potential for additional seating for cafes and restaurants. Third Street's bike lane will feed into a larger bicycle network that connects to the Sixth Street Viaduct project. 


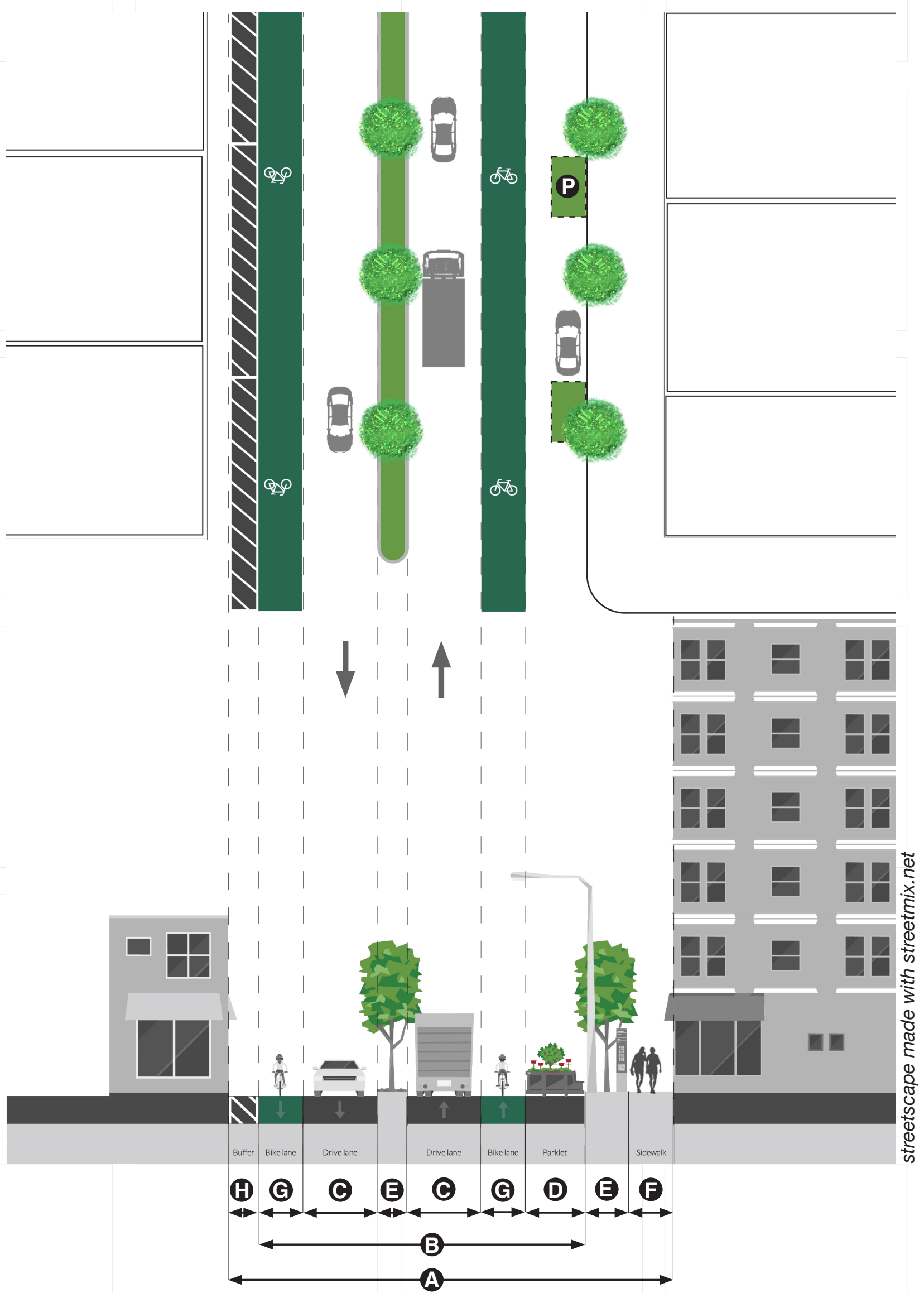




\section{Concepts for Specific Streets - S. Santa Fe Avenue}

(3rd Street to 4th Street)

\begin{tabular}{lll}
\hline Application & & \\
\hline Movement Type & Slow & \\
\hline Design Speed & $25 \mathrm{mph}$ & \\
\hline Pedestrian Crossing Time & 9.2 seconds & \\
Transect Zone & T5 & \\
\hline Overall Widths & & \\
\hline Right-of-Way (ROW) Width & $60^{\prime}$ & $\mathbf{A}$ \\
\hline Curb Face to Curb Face Width & $44^{\prime}$ & $\mathbf{B}$ \\
\hline Lanes & & \\
\hline Traffic Lanes & $10^{\prime}$ & $\mathbf{C}$ \\
\hline Parking Lane & 8' parallel $^{1}$ & D \\
\hline Bicycle Lanes & 6' painted & G \\
\hline
\end{tabular}

\begin{tabular}{|c|c|}
\hline Medians & $\begin{array}{l}\text { 4'Trees and } \\
\text { landscaped }\end{array}$ \\
\hline \multicolumn{2}{|l|}{ Edges } \\
\hline Curb Type & Square \\
\hline Planter Type & $\begin{array}{l}4^{\prime} \text { continuous } \mathbf{E} \\
\text { with breaks for } \\
\text { parking access } \\
\text { and tree wells }\end{array}$ \\
\hline Landscape Type & $\begin{array}{l}\text { Trees spaced at } \\
30^{\prime} \text { o.c. average* }\end{array}$ \\
\hline Walkway Type & 8' Sidewalk $\quad \boldsymbol{E}$ \\
\hline Buffer & 4' painted \\
\hline \multicolumn{2}{|l|}{ Notes } \\
\hline \multicolumn{2}{|c|}{$\begin{array}{l}{ }^{*} \text { All medians, planters, and landscapes should } \\
\text { follow Low Impact Development Standards } \\
\text { 'Parklets are encouraged as a form of open } \\
\text { space adjacent to active commercial uses such as } \\
\text { cafes or restaurants. }\end{array}$} \\
\hline
\end{tabular}

\section{S. Santa Fe Avenue (3rd to 4th Street)}

The section of S. Santa Fe Avenue between Third Street and the Fourth Street Bridge will be designed to accommodate an urban street with slow moving traffic, painted bike lanes, and a variety of land uses. S. Santa Fe Avenue will continue the existing painted bike lane from Third Street until Fourth Street. Landscaping on the eastern sidewalk will redefine the thoroughfare to host a canopy of trees and plant life to implement low impact development strategies. The street will provide parallel parking on the eastern side and a small buffer on its western side between the street and adjacent land uses. Parklets on S. Santa Fe Avenue's eastern side will provide open space for industrial workers, students and faculty of SCl-Arc, and residents of the Arts District. 


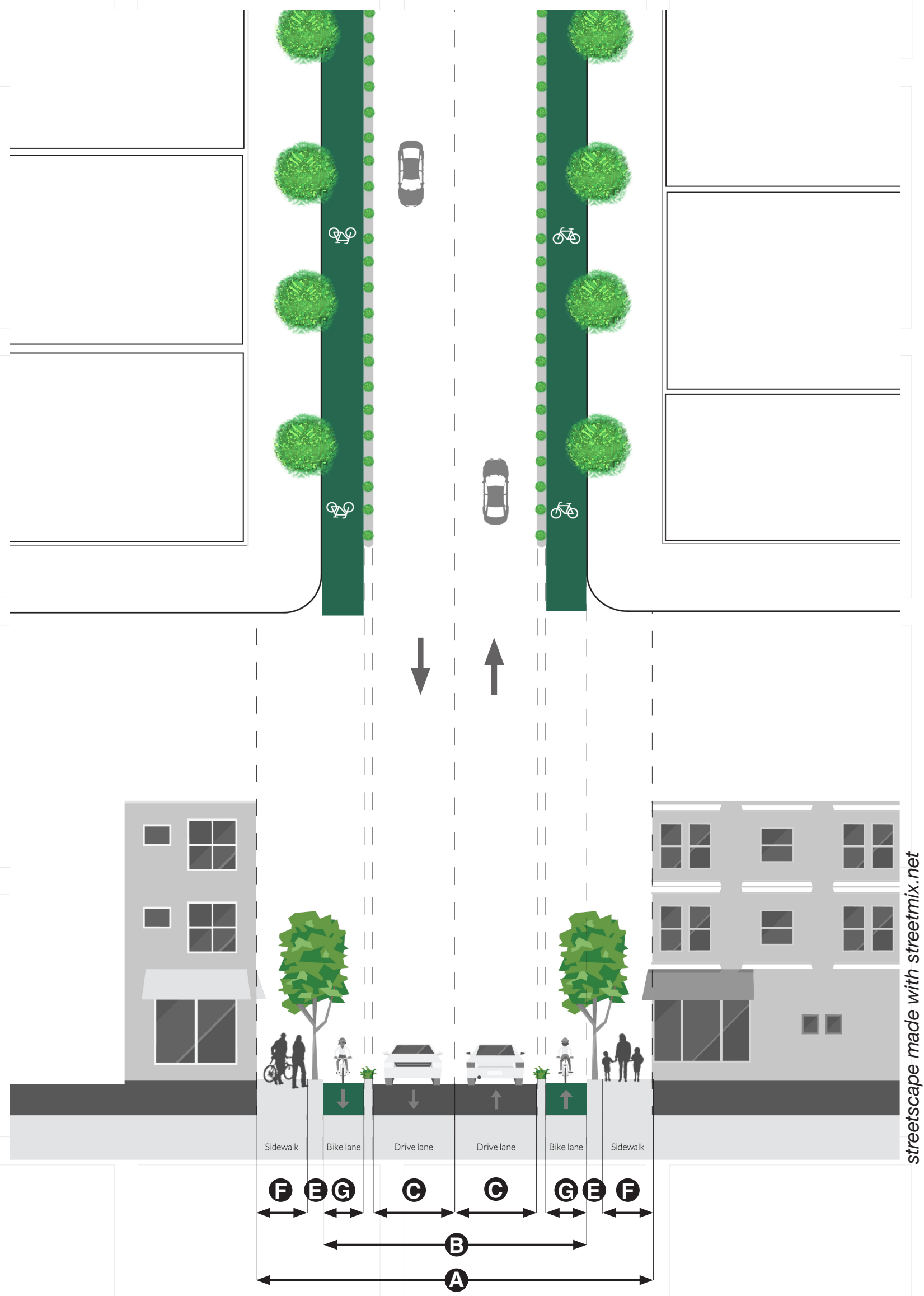


Concepts for Specific Streets - S. Santa Fe Avenue (4th Street to 7th Street)

\begin{tabular}{lll}
\hline Application & & \\
\hline Movement Type & Slow & \\
\hline Design Speed & $25 \mathrm{mph}$ & \\
\hline Pedestrian Crossing Time & 8 seconds & \\
Transect Zone & SD & \\
\hline Overall Widths & & \\
\hline Right-of-Way (ROW) Width & $50^{\prime}$ & $\mathbf{A}$ \\
\hline Curb Face to Curb Face Width & $34^{\prime}$ & $\mathbf{B}$ \\
\hline Lanes & & \\
\hline Traffic Lanes & $10^{\prime}$ & $\mathbf{C}$ \\
\hline Parking Lane & None & \\
\hline Bicycle Lanes & 5' painted & G \\
\hline
\end{tabular}

\begin{tabular}{ll}
\hline Medians & None \\
\hline Edges & \\
\hline Curb Type & Square \\
\hline Planter Type & 2' continuous* $\mathbf{E}$ \\
\hline Landscape Type & Trees spaced at \\
& 30' o.c. average \\
\hline Walkway Type & 6' Sidewalk $\quad \mathbf{E}$ \\
\hline Buffer & 1' planted \\
\hline Notes & \\
\hline
\end{tabular}

${ }^{*}$ All medians, planters, and landscapes should follow Low Impact Development Standards

\section{S. Santa Fe Avenue (4th to 7th Street)}

The section of S. Santa Fe Avenue between Fourth Street and the Seventh will be designed to accommodate an urban industrial street with slow moving traffic, painted bike lanes, and a variety of land uses. S. Santa Fe Avenue will continue the extended bike route from Fourth Street until Seventh Street. The extension of the bike lane will strengthen the connection between the southern and northern portion of the Arts District while offering enhanced linkages to the Sixth Street Viaduct and LA River. Landscaping on the sidewalk will redefine the thoroughfare to host a canopy of trees and plant life to implement low impact development strategies. The street will maintain its current no parking regulation on both sides. 


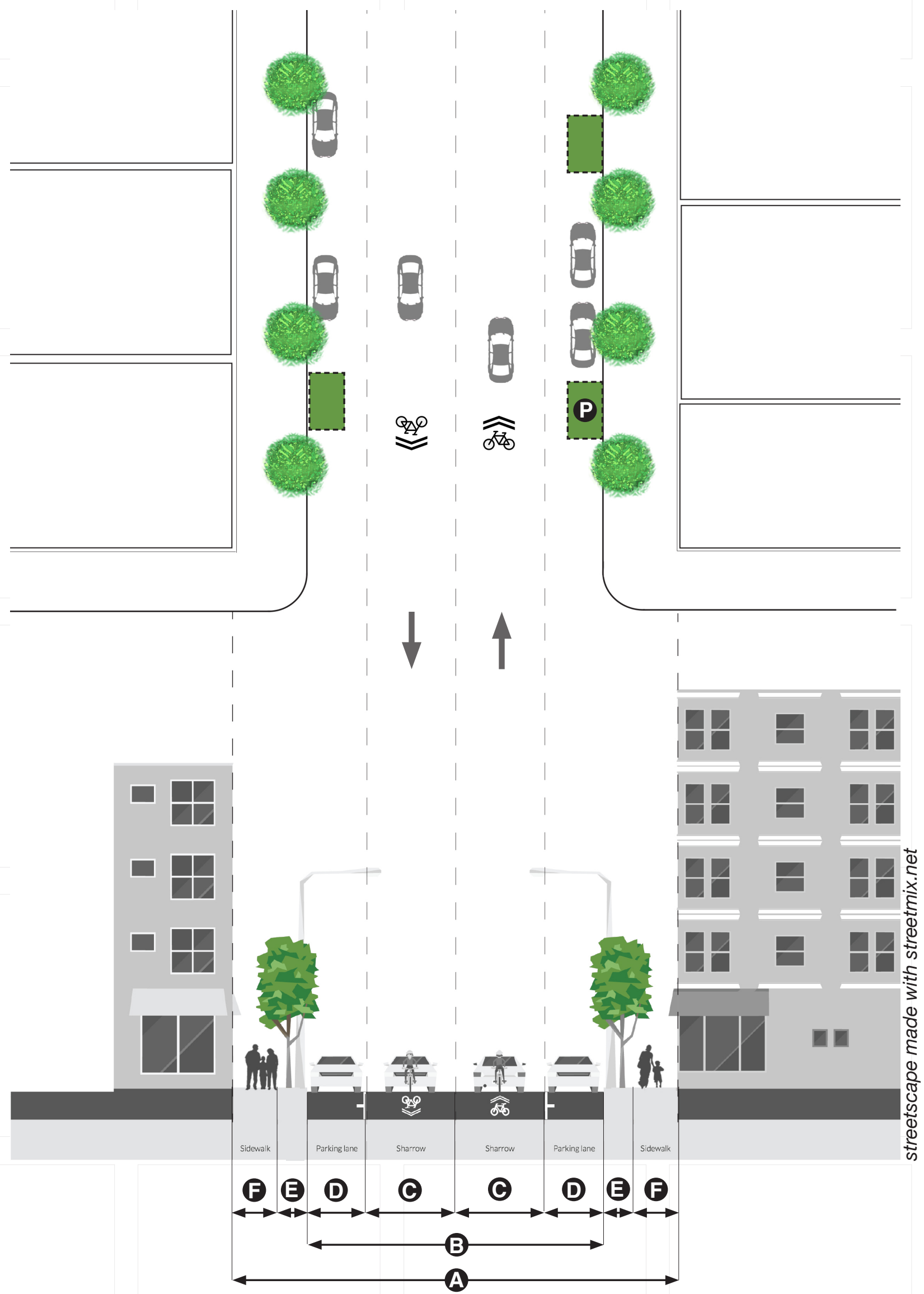




\section{Concepts for 60' Urban Street}

\begin{tabular}{lll}
\hline Application & & \\
\hline Movement Type & Slow & \\
\hline Design Speed & $25 \mathrm{mph}$ & \\
\hline Pedestrian Crossing Time & 9 seconds & \\
Transect Zone & T5, SD & \\
\hline Overall Widths & & \\
\hline Right-of-Way (ROW) Width & $58^{\prime}-60^{\prime}$ & $\mathbf{A}$ \\
\hline Curb Face to Curb Face Width & $38^{\prime}-40^{\prime}$ & $\mathbf{B}$ \\
\hline Lanes & & \\
\hline Traffic Lanes & $10^{\prime}-12^{\prime}$ & $\mathbf{C}$ \\
\hline Parking Lane & ${\text { 8' } \text { parallel }^{1}}^{\prime}$ & D \\
\hline Bicycle Lanes & Sharrowed $^{2}$ & G \\
\hline
\end{tabular}

\begin{tabular}{ll}
\hline Medians & None \\
\hline Edges & Square \\
\hline Curb Type & $\begin{array}{l}\text { 4' continuous } \\
\text { with breaks for } \\
\text { parking access } \\
\text { and tree wells }\end{array}$ \\
\hline Planter Type & $\begin{array}{l}\text { Trees spaced at } \\
\text { 30' o.c. average* }\end{array}$ \\
\hline Landscape Type & 6' Sidewalk $\mathbf{E}$ \\
\hline Walkway Type & \\
\hline Notes & \\
\hline *All medians, planters, and landscapes should \\
follow Low Impact Development Standards \\
'Parklets are encouraged as a form of open \\
$\begin{array}{l}\text { space adjacent to active commercial uses such as } \\
\text { cafes or restaurants. } \\
\text { 2Sharrowed bicycle lane optional and should reflect } \\
\text { connections to larger bicycle network. }\end{array}$
\end{tabular}

\section{0' Street Width Concept}

Streets with an approximate 60' width will accommodate an urban street characterized by slow moving traffic, optional sharrowed bike lanes, and variety of land uses. Landscaping on the sidewalk will redefine the thoroughfare to host a canopy of trees and plant life to implement low impact development strategies. Sidewalks will house street furniture, landscaping, and bicycle parking. The street will accommodate parallel parking. Parklets along both sides of the street are to be located near active commercial uses to provide open space and have the potential for additional seating for cafes and restaurants. Sharrowed bike lanes should be added along streets with potential for future bike lanes and connections to a greater bicycle or open space network. 


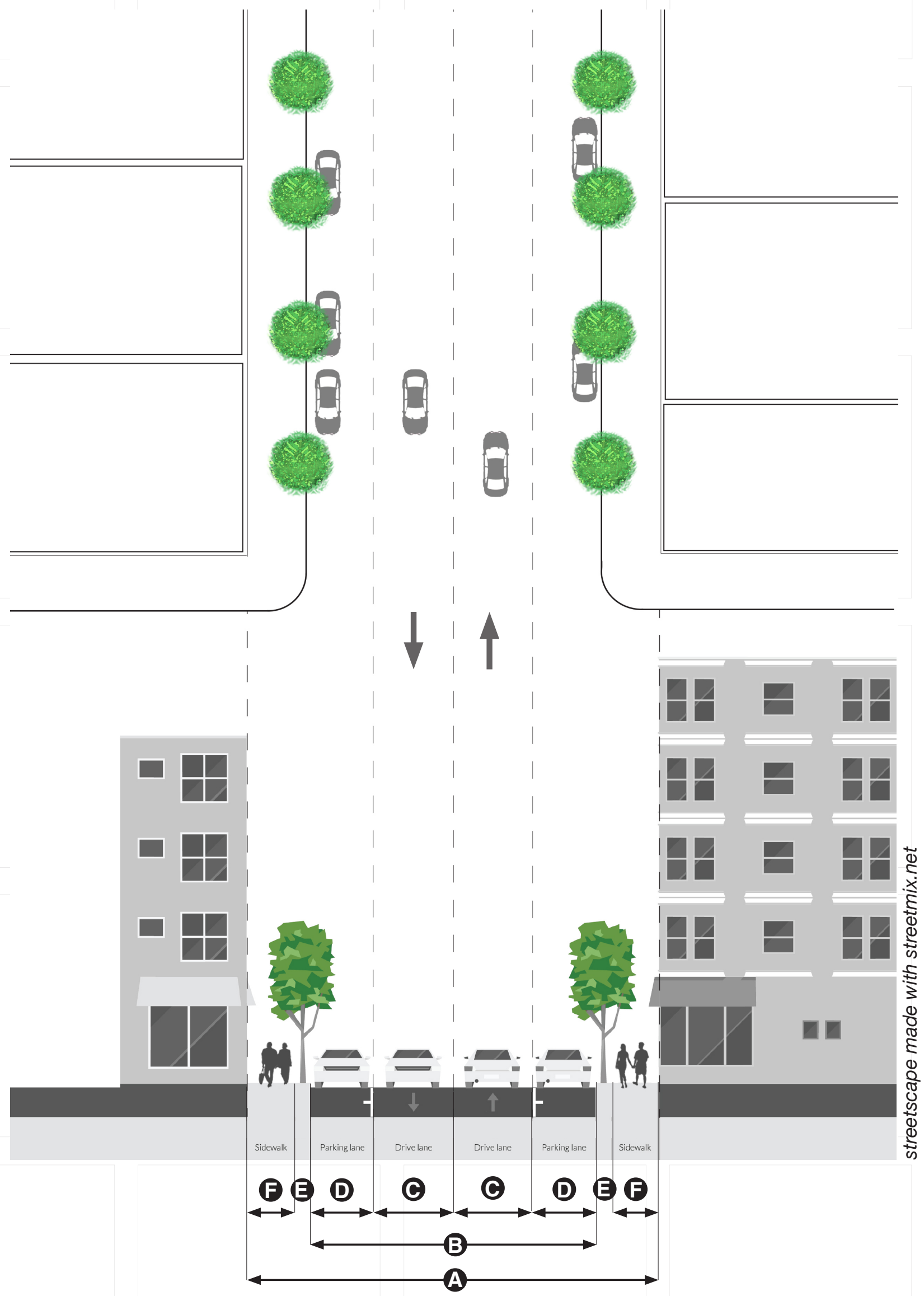


Concepts for 50' Urban Street

\begin{tabular}{|c|c|c|c|c|}
\hline \multicolumn{3}{|l|}{ Application } & Medians & None \\
\hline Movement Type & \multicolumn{2}{|l|}{ Slow } & \multicolumn{2}{|l|}{ Edges } \\
\hline Design Speed & \multicolumn{2}{|l|}{$25 \mathrm{mph}$} & Curb Type & Square \\
\hline Pedestrian Crossing Time & \multirow{2}{*}{\multicolumn{2}{|c|}{8 seconds }} & \multirow[t]{3}{*}{ Planter Type } & \multirow{3}{*}{$\begin{array}{l}\text { 2' continuous } \mathbf{\Theta} \\
\text { with breaks for } \\
\text { parking access } \\
\text { and tree wells* }\end{array}$} \\
\hline Transect Zone & & & & \\
\hline \multicolumn{3}{|l|}{ Overall Widths } & & \\
\hline Right-of-Way (ROW) Width & $50^{\prime}-52^{\prime}$ & A & \multirow[t]{2}{*}{ Landscape Type } & \multirow{2}{*}{$\begin{array}{l}\text { Trees spaced at } \\
30^{\prime} \text { average }^{\star}\end{array}$} \\
\hline Curb Face to Curb Face Width & $34^{\prime}-36^{\prime}$ & B & & \\
\hline \multicolumn{3}{|l|}{ Lanes } & Walkway Type & 6' Sidewalk $\boldsymbol{E}$ \\
\hline Traffic Lanes & $10^{\prime}$ & C & \multicolumn{2}{|c|}{ Notes } \\
\hline Parking Lane & 7-8' parallel & (D) & \multirow{2}{*}{\multicolumn{2}{|c|}{$\begin{array}{l}{ }^{*} \text { All medians, planters, and landscapes should } \\
\text { follow Low Impact Development Standards. }\end{array}$}} \\
\hline Bicycle Lanes & \multicolumn{2}{|l|}{ None } & & \\
\hline
\end{tabular}

\section{0' Street Width Concept}

Streets with an approximate 50' width will accommodate an urban street characterized by slow moving traffic and variety of land uses. Landscaping on the sidewalk will redefine the thoroughfare to host a canopy of trees and plant life to implement low impact development strategies. Sidewalks will house street furniture, landscaping, and bicycle parking. The street will accommodate parallel parking. 


\section{Conclusion}

The Arts District neighborhood is a juxtaposition of art and industry. The artists have a unique synergy with the industrial building fabric. It is this impromptu collaboration of industrial buildings as a canvas, an outlet, for art that defines the identity of the Arts District. In addition the history of the railroad present in the building stock, compact road system, hidden railroad tracks, and creativity and innovation have developed the community into what it is today. The popularity of the area as a cultural attraction and its proximity to a bustling downtown will continue its presence as unique and vibrant neighborhood. Building development is only expected to increase as market forces determine the need for housing, commercial, and industrial space. The challenge for the Arts District will be the allocation of resources for residents versus existing industrial users and new development. As new residents settle in the area issues such as parking, open space, and pedestrian infrastructure will have to be further addressed. Even with an expected loss to heavier industrial land uses, jobs can be retained or even grown through further implementation of a Los Angeles Cleantech corridor. This will allow the Arts District to foster a new wave of technological creativity and possibly rebrand itself over time. However, the risk will always be the loss of historic buildings that give the area is unique urban character. The continued and expanded preservation of the Arts District historical buildings is paramount to its continued success as a cultural destination for Los Angeles. Finally, as the area evolves it will have to responsibly manage future projects, circulation, land-use and culture to remain one of Los Angeles' most unique and sought after neighborhoods. 



\section{References}

City of San Francisco Planning Department. (2013). San Francisco Parklet Manuel.

Community Redevelopment Agency of the City of Los Angeles California. (2007). Central Industrial Redevelopment Project Area: Five Year Implementation Plan 2008-2012.

Community Redevelopment Agency of the City of Los Angeles California. (2007). Los Angeles' Industrial Land: Sustaining a Dynamic City Economy.

Coldwell Banker Richard Ellis Global Research and Consulting. (2014). Greater Los Angeles Industrial Market View.

Department of City Planning and the Community Redevelopment Agency of the City of Los Angeles. (2007). Los Angeles' Industrial Land: Sustaining A Dynamic City Economy.

Duany Plater-Zyberk \& Company, Chellman, C., Hall, R., Swift, P. (Retrieved 2014). Complete Streets Module.

Duany Plater-Zyberk \& Company. (2003). SmartCode Version 9.2

Duany Plater-Zyberk \& Company. (Retrieved 2014). Thoroughfare Standards Replacement SmartCode Module.

Historic Cultural Neighborhood Council. (2006). Uncommon Ground I: Visions for the LA Arts District.

Historic Cultural Neighborhood Council. (2012). Uncommon Ground III: Imagining a Future for the Arts District.

Jaime Correa and Associates, with Maria Bendfeldt and Jennifer Hamilton. (Retrieved 2014). Renewable Resources SmartCode Module.

Los Angeles Conservancy. (2013). The Arts District: History and Architecture in Downtown LA.

Los Angeles County Bicycle Coalition. (2013). Bicycle Parking Ordinances: Examples from the United States. 
Los Angeles Department of City Planning. (2000). City of Los Angeles General Plan, Central City North Community Plan.

Los Angeles Department of City Planning. (2014). General Plan Structure: Summary of the General Plan Elements.

Los Angeles Department of City Planning. (2006). Generalized Summary of Zoning Regulations City of Los Angeles.

Los Angeles Department of City Planning. (2007). Interim Procedures Regarding Applications fot Residential Projects on Industrial Zoned Property Determined to Be No Longer Viable For Industrial Use.

Los Angeles Daily Journal. (1981). Joint living and work Quarters Amendment. Ordinance No. 155843.

Los Angeles Department of City Planning. (2010). Joint Living and Work Quarters Ordinance: 181133.

Los Angeles Department of City Planning. (2013). Mural Ordinance: 182706.

Los Angeles Department of City Planning. (2008) Case No. CPC-2008-3417GPA Plan Amendment.

Los Angeles Department of City Planning. (2009). Transmittal to City Council. Case No. CPC-2009-1771-CA Joint Living and Work Quarters.

Los Angeles Department of City Planning Recommendation Report. (2008). General Plan Amendment to Arts District Boundary. Case No. CPC-20083417-GPA

Los Angeles Department of Public Works. (2009). Green Streets and Green Alleys Design Guidelines Standards.

Lydon, M., Adelson, Z., Garcia, T. (2008). Bicycling SmartCode Module.

Urban Land Institute. (2010). Cleantech Corridor Los Angeles, California. An Advisory Services Program Report. 
